IZA DP No. 5736

Gender Earnings Gaps in the World

Hugo Ñopo

Nancy Daza

Johanna Ramos

May 2011 


\title{
Gender Earnings Gaps in the World
}

\author{
Hugo Ñopo \\ Inter-American Development Bank \\ and IZA \\ Nancy Daza \\ National Planning Department, Colombia \\ Johanna Ramos \\ National Planning Department, Colombia
}
Discussion Paper No. 5736
May 2011

IZA
P.O. Box 7240
53072 Bonn
Germany

Phone: +49-228-3894-0

Fax: +49-228-3894-180

E-mail: iza@iza.org

Any opinions expressed here are those of the author(s) and not those of IZA. Research published in this series may include views on policy, but the institute itself takes no institutional policy positions.

The Institute for the Study of Labor (IZA) in Bonn is a local and virtual international research center and a place of communication between science, politics and business. IZA is an independent nonprofit organization supported by Deutsche Post Foundation. The center is associated with the University of Bonn and offers a stimulating research environment through its international network, workshops and conferences, data service, project support, research visits and doctoral program. IZA engages in (i) original and internationally competitive research in all fields of labor economics, (ii) development of policy concepts, and (iii) dissemination of research results and concepts to the interested public.

IZA Discussion Papers often represent preliminary work and are circulated to encourage discussion. Citation of such a paper should account for its provisional character. A revised version may be available directly from the author. 
IZA Discussion Paper No. 5736

May 2011

\section{ABSTRACT}

\section{Gender Earnings Gaps in the World}

This paper documents gender disparities in labor earnings for sixty-four countries around the world. Disparities are partially attributed to gender differences in observable sociodemographic and job characteristics. These characteristics are used to match males and females such that gender earnings disparities are computed only among individuals with the same characteristics, as in Ñopo (2008). After comparing males and females with the same characteristics we found that the earnings gap falls within a range between $8 \%$ and $48 \%$ of average females' earnings, being more pronounced in South Asia and Sub-Saharan Africa. The unexplained earnings gaps are more pronounced among part-time workers and those with low education.

JEL Classification: $\quad$ C14, D31, J16, O57

Keywords: gender, wage gaps, matching

Corresponding author:

Hugo Ñopo

Inter-American Development Bank

Colombia Country Office

Carrera 7 ma 71 - 21, Torre B, Piso 19

Bogotá

Colombia

E-mail: hugon@iadb.org

\footnotetext{
This paper was prepared for the World Development Report 2012: Gender Equality and Development. Daza and Ramos received financial support from the World Bank for this purpose. The views expressed are those of the authors and do not necessarily reflect the views of neither the World Bank nor the Inter-American Development Bank. The comments of Felipe Balcazar are especially acknowledged.
} 


\section{Introduction and Literature Review}

The literature on gender disparities has been abundant. Several pieces have examined not only the magnitude but also the reasons behind earnings gaps between men and women, its persistence, evolution, and its impact on economic welfare and development. Among the aspects that have been usually attributed to explain the differences are the personal and job characteristics of women (age, education, experience, occupation, working time, job status, type of contract), the labor market structure (occupational segregation by gender, level of formality), and institutional, cultural and social norms and traditions. The literature varies not only in terms of methodologies and results, but also in the policy recommendations aimed to improve the opportunities and economic participation of women. This paper pretends to contribute to this literature providing a comprehensive view of earnings disparities in the world, comparing different regions with the same methodological approach and attempting to identify commonalities across the globe.

We made a descriptive analysis of the data set by regions regarding gender socio-demographic and labor characteristics, then, we use Nopo (2008) matching procedure to compute and analyze the wage gap, attributing disparities to these characteristics. But first, in this section, we briefly summarize the literature by world's regions highlighting only some relevant pieces for our endeavor. We also provide an annex that contains a more comprehensive table (but by no means exhaustive) of the literature reviewed with summaries for each reviewed paper.

Globally, one of the first patterns that arises is that economic development or market liberalization does not mean narrower gender differences. Different studies have shown that there is no relationship between economic growth and the narrowing of earnings gaps against women (Hertz et al., 2008; Blau and Kahn, 2001; Tzannatos, 1999). This result has been robust to different methodologies and data sets. Weichselbaumer et al. (2007) report that the unexplained component of the gender gap, estimated with Oaxaca-Blinder decompositions, has been negatively related with further liberalization of markets.

Other reasons that have been found to be linked to gender earnings disparities are: sectorial segregation to lower wage sectors against women (Tzannatos, 1999), lower female net supply and wage structure (Blau and Kahn, 2001), labor market liberalization and institutional frame in each country (Weichselbaumer et al., 2007; Blau and Kahn, 2001; Cornish, 2007 and Tzanatos 1999), among others. 
The magnitude and heterogeneity of the gender earnings gap notoriously varies across studies. Blau et al. (2001) report that the gap is as low as $14.4 \%$ for Slovenia and as high as $85 \%$ for Japan. Along with Japan, Switzerland, United States, Great Britain and Russia also show high gender earnings disparities in this study. On the lowest extreme of gender gaps, along with Slovenia, many other Eastern European countries can be found. Fetherolf (2001) reports gender earnings disparities shows on a range that goes from $53.5 \%$ (Rep. of Korea) to 106\% (Swaziland), with all other countries varying in a range between 65 and $92 \%$. The countries in the OECD did not have a significant narrower wage gap than other countries with similar development levels. Hausmann et al. (2010) report Oceania as the region with the lowest gender earnings gap and North America, the United Kingdom and Asia on the other extreme with the highest gaps. Some brief accounts of the literature by region are summarized as follows.

Sub-Saharan Africa: Different endowments, different opportunities. Labor force education, work allocation with gender selection, and different unemployment rates by gender seem to be the key drivers of gender earnings disparities in this region. For instance, in Ethiopia, education accounts for around one-fifth of pay differences and it works as a passport to enter into the public sector, a sector that offers better wages and labor conditions (Kolev and Suarez, 2010; Suarez, 2005). For a more comprehensive set of countries, it has been found an important role for education on reducing wage differences (Kolev and Sirven, 2010). It has been also reported that women tend to work more hours than men but they tend to be found more often among unpaid family workers and domestic workers (Suarez, 2005; Wodon and Ying, 2010). Unemployment is more prevalent among women but the relationship between education and unemployment has not been conclusive (Nordman et al., 2010). All in all, almost one-half of observed gender earnings disparities fail to be explained by observable characteristics.

Europe and Central Asia: transition economies with segregation. The economic and political transition of last decades has received special attention in the ECA region. Most studies agree on the relative improvement of females' wages in most countries of the region (Brainerd, 2000). Increased wage inequality in Eastern Europe have worked towards depressing female relative wages, but these losses have been more than offset by gains in rewards to observed skills and by a decline in the unobservable component of the earnings gap. Still, female segregation into low-wage occupations emerges as the main contributor to the gender pay gap (Simon). Along similar lines, the public-private divide seems to play an important role as well. When controlling for observed characteristics and sample selection, public administration wages are higher than private sector wages in the case of 
men, except at the university level where the wages are equal. State-owned enterprises' wages are higher than those in the private sector. Further, while wages of men and women are at parity in the public administration sector, there is a large gender wage-gap in the private sector in favor of men (Tansel, 2004)

East Asia and the Pacific: The impact of the economic and political reforms. It has been documented that the economic liberalization policies of 1986 did not have an important effect on reducing the gender wage gap. For the last decades there is no clear agreement on the tendency that the gender earnings gaps have followed. The overall difference shave narrowed but the unexplained component of the gap, overall, has not (Liu, 2001, 2004; Son, 2007). The results seem to show that it has reduced in some percentiles of the earnings distribution (Pham and Reilly, 2006). The reduction of the gap, when observed, has been mainly due to a reduction on observed gender differences in characteristics. However, the unexplained component of the earnings gap seems to be explaining most of the observed gaps. Education also plays an important role in explaining wage differentials in this region. In Indonesia it has been documented that earnings disparities by gender shows an inverted $U$ profile with respect to education (Pirmana, 2006). The evidence for Mongolia shows that early career wages are not different between genders. Despite this, on later stages of their careers women earn less than males, but higher educated women partially overcome such gap (Pastore, 2010).

Western Europe: Occupational and industry segregation. Part of the literature shows that wage differentials are mainly explained by the female segregation into low-wage jobs (Daly et al., 2006), but it has also been documented the existence of significant inter-industry wage differentials in all countries for both sexes (Gannon et al., 2006). Other studies support the idea that gender pay gaps are typically bigger at the top of the wage distribution and that the gender pay gap differs significantly across the public and private sector wage distribution of each country (Arulampalam et al., 2004).

This paper presents a comprehensive view of gender earnings gaps in the world, simultaneously exploring many of the issues highlighted in this brief literature review. This will be done, however, with the advantage of exploring them from a comparative perspective, applying the same methods for all data across the world. In order to perform such world comparison, the data from different sources (national household surveys) is harmonized first, making them comparable. This is shown in the next section. After that, the main section of this paper is devoted to the comparison of unexplained gender earnings gaps for different world regions. Next, an attempt of linking unexplained gender earnings 
gaps to some political and social world indicators is made and finally the paper closes with some brief concluding remarks.

\section{The Data}

This exercise of gender earnings gaps decompositions has been performed for 64 countries. The data sources have been any sort of nationally representative household survey available with information on labor earnings and observable characteristics of the individuals and their jobs ${ }^{1}$. The countries have been grouped into regions: East Asian and Pacific (EAP), Europe and Central Asia (ECA), Middle East and North Africa (MENA), South Asia (SA), Western Europe and Sub-Saharan Africa (SSA). Note that this paper does not include the Latin America and the Caribbean (LAC) regions ${ }^{2}$. The data from all countries was pooled restricting the analysis to working individuals between 18 and 65 years old, reporting positive earnings at their main activity and with no missing information on their demographic characteristics.

The demographic characteristics considered for the analysis are: age, region (urban/rural), education (measured in levels), marital status, and presence of children (younger than 12 years old) at the household, presence of elderly (older) than 65 years old at the household and presence of other household members who generate labor income. On top of these demographics, information on job characteristics has also been used: hours of work per week, employment status, occupation, economic sector and formality (social security coverage). Labor hourly earnings have been expressed in constant 2008 dollars using PPP-corrected exchange rates and GDP deflators. All labor characteristics considered in the analysis, including earnings, have been considered only for the main occupation. The expansion factors from each survey have been used such that when pooling all data the number of expanded observations per country is proportional to their corresponding population sizes.

Not all the surveys have the same individuals' information. Hence, the estimations have been carried out for two groups of countries based on data availability. The first group, the full set of countries, uses formality as control variable. This comprises 21 countries from SSA, MENA, ECA and EAP regions. The second group allows controlling for economic sector; this group comprises 14

\footnotetext{
${ }^{1}$ For more details about the harmonization of the data sets, see Montenegro and Hirn (2009).

${ }^{2}$ The gender earnings gaps decomposition for these countries can be found in two companion papers: Atal, Ñopo and Winder (2009) and Hoyos and Ñopo (2010).
} 
countries from SA and Western Europe regions ${ }^{3}$. The whole countries in the analyses allow the inclusion of the hours of work per week and type of employment and occupation, variables.

Table 1 displays the list of available countries on each group classified by region, including the number of available observations (that is, those that remain after dropping observations with missing values, zero labor income, or those out of the range 18 to 65 years old) after sequentially adding hours of work per week, type of employment, occupations, economics sector and formality into the analysis.

\footnotetext{
${ }^{3}$ These regions are controlled for economic sector because for the first region all the individuals are informal (that is, they are not covered by social security) and in the second region all the individuals are formal (covered by social security), in this way social security is not a proper control for informality.
} 
Table 1. Available Countries by Set and Region

\begin{tabular}{|c|c|c|c|c|c|c|c|c|c|}
\hline \multirow[b]{2}{*}{ Region } & \multirow[b]{2}{*}{ Country } & \multirow[b]{2}{*}{ Year } & \multicolumn{5}{|c|}{ Set } & \multirow[b]{2}{*}{ Observations* } & \multirow{2}{*}{$\begin{array}{l}\text { Weighted } \\
\text { Observations }\end{array}$} \\
\hline & & & $\begin{array}{l}+ \text { Hours } \\
\text { of work }\end{array}$ & $\begin{array}{l}\text { +Type of } \\
\text { employment }\end{array}$ & +Occupation & $\begin{array}{c}+ \\
\text { Economic } \\
\text { Sector }\end{array}$ & Full Set & & \\
\hline \multirow{20}{*}{ क } & COTE D'IVOIRE & 2002 & $\mathrm{X}$ & $X$ & & & & 8,835 & $1,848,307$ \\
\hline & CAMEROON & 2007 & $\mathrm{X}$ & $\mathrm{X}$ & & & & 9,942 & $3,542,248$ \\
\hline & COMOROS & 2004 & $\mathrm{X}$ & $\mathrm{X}$ & $\mathrm{X}$ & $\mathrm{X}$ & $X$ & 1,939 & 63,388 \\
\hline & CONGO & 2005 & $\mathrm{X}$ & $\mathrm{X}$ & $\mathrm{X}$ & $\mathrm{X}$ & $\mathrm{X}$ & 7,442 & $6,180,549$ \\
\hline & ETHIOPIA & 2005 & $\mathrm{X}$ & $\mathrm{X}$ & & & & 20,663 & $2,014,380$ \\
\hline & GABON & 2005 & $\mathrm{X}$ & $\mathrm{X}$ & & & & 7,918 & 300,853 \\
\hline & GHANA & 2005 & $\mathrm{X}$ & $\mathrm{X}$ & $\mathrm{X}$ & $\mathrm{X}$ & $X$ & 8,653 & $4,518,128$ \\
\hline & KENYA & 2005 & $\mathrm{X}$ & $\mathrm{X}$ & $\mathrm{X}$ & $\mathrm{X}$ & & 7,284 & $3,966,704$ \\
\hline & MADAGASCAR & 2001 & $\mathrm{X}$ & $\mathrm{X}$ & $\mathrm{X}$ & $\mathrm{X}$ & $X$ & 2,731 & $1,227,875$ \\
\hline & MOZAMBIQUE & 1996 & $\mathrm{X}$ & $\mathrm{X}$ & $\mathrm{X}$ & $\mathrm{X}$ & & 1,877 & 526,543 \\
\hline & MAURITANIA & 2000 & $\mathrm{X}$ & $\mathrm{X}$ & & & & 3,602 & 178,802 \\
\hline & MAURITIUS & 2003 & $\mathrm{X}$ & $\mathrm{X}$ & $\mathrm{X}$ & $X$ & & 9,069 & 9,069 \\
\hline & MALAWI & 2005 & $\mathrm{X}$ & $\mathrm{X}$ & & & & 3,056 & 718,149 \\
\hline & NIGER & 2002 & $\mathrm{X}$ & $\mathrm{X}$ & & & & 1,515 & 60,348 \\
\hline & NIGERIA & 2003 & $\mathrm{X}$ & $X$ & $\mathrm{X}$ & $X$ & $X$ & 1,745 & $3,217,024$ \\
\hline & RWANDA & 2005 & $\mathrm{X}$ & $\mathrm{X}$ & $\mathrm{X}$ & $X$ & & 3,569 & 887,725 \\
\hline & CHAD & 2002 & $\mathrm{X}$ & $\mathrm{X}$ & & & & 4,943 & 918,357 \\
\hline & TANZANIA & 2006 & $\mathrm{X}$ & $\mathrm{X}$ & $\mathrm{X}$ & $\mathrm{X}$ & $X$ & 11,707 & $5,524,172$ \\
\hline & UGANDA & 2005 & $\mathrm{X}$ & $X$ & $\mathrm{X}$ & $X$ & & 3,271 & $2,301,786$ \\
\hline & $\begin{array}{l}\text { NO. OF COUNTRIES } \\
\text { TOTAL }\end{array}$ & & 19 & 19 & 11 & 11 & 6 & 119,761 & $38,004,407$ \\
\hline \multirow{5}{*}{ 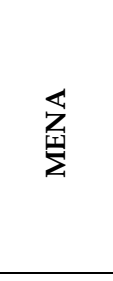 } & EGYPT & 1998 & $X$ & $X$ & $X$ & $X$ & & 2,873 & $6,622,328$ \\
\hline & MOROCCO & 1991 & $X$ & $X$ & $\mathrm{X}$ & & & 1,900 & $2,607,931$ \\
\hline & TUNISIA & 2001 & $X$ & $X$ & $X$ & $X$ & $X$ & 25,520 & $1,249,731$ \\
\hline & YEMEN & 2005 & $\mathrm{X}$ & $\mathrm{X}$ & $\mathrm{X}$ & $X$ & $X$ & 7,158 & $1,241,521$ \\
\hline & $\begin{array}{l}\text { NO. OF COUNTRIES } \\
\text { TOTAL }\end{array}$ & & 4 & 4 & 4 & 3 & 2 & 37,451 & $11,721,511$ \\
\hline \multirow{14}{*}{$\bigcup_{i=1}^{\mathbb{1}}$} & ALBANIA & 2002 & $X$ & $X$ & $\mathrm{X}$ & $X$ & $X$ & 2,155 & 416,072 \\
\hline & BULGARIA & 2008 & $\mathrm{X}$ & $\mathrm{X}$ & $\mathrm{X}$ & $\mathrm{X}$ & $\mathrm{X}$ & 3,689 & $2,539,627$ \\
\hline & $\begin{array}{l}\text { BOSNIA AND } \\
\text { HERZEGOVINA }\end{array}$ & 2001 & $\mathrm{X}$ & $\mathrm{X}$ & $\mathrm{X}$ & $\mathrm{X}$ & $X$ & 3,482 & 669,402 \\
\hline & CZECH REPUBLIC & 2008 & $\mathrm{X}$ & $\mathrm{X}$ & $\mathrm{X}$ & $\mathrm{X}$ & $\mathrm{X}$ & 7,990 & $3,074,162$ \\
\hline & ESTONIA & 2008 & $\mathrm{X}$ & $\mathrm{X}$ & $\mathrm{X}$ & $\mathrm{X}$ & $X$ & 4,978 & 552,748 \\
\hline & CROATIA & 2004 & $\mathrm{X}$ & $\mathrm{X}$ & $\mathrm{X}$ & $\mathrm{X}$ & $\mathrm{X}$ & 4,831 & $1,083,146$ \\
\hline & HUNGARY & 2008 & $\mathrm{X}$ & $X$ & $\mathrm{X}$ & $X$ & $X$ & 7,142 & $3,241,095$ \\
\hline & KYRGYZSTAN & 1997 & $\mathrm{X}$ & $\mathrm{X}$ & & & & 2,238 & 915,574 \\
\hline & LITHUANIA & 2008 & $\mathrm{X}$ & $\mathrm{X}$ & $X$ & $X$ & & 4,826 & $1,425,343$ \\
\hline & LATVIA & 2008 & $\mathrm{X}$ & $\mathrm{X}$ & $\mathrm{X}$ & $\mathrm{X}$ & $X$ & 4,478 & 844,832 \\
\hline & MOLDOVA & 2002 & $\mathrm{X}$ & $\mathrm{X}$ & $\mathrm{X}$ & $\mathrm{X}$ & $\mathrm{X}$ & 3,541 & 843,473 \\
\hline & MONTENEGRO & 2006 & $\mathrm{X}$ & $X$ & & & & 555 & 112,875 \\
\hline & POLAND & 2008 & $\mathrm{X}$ & $X$ & $\mathrm{X}$ & $X$ & $X$ & 7,754 & $8,747,305$ \\
\hline & ROMANIA & 2008 & $\mathrm{X}$ & $\mathrm{X}$ & $\mathrm{X}$ & $\mathrm{X}$ & & 6,242 & $7,408,127$ \\
\hline
\end{tabular}




\begin{tabular}{|c|c|c|c|c|c|c|c|c|c|}
\hline & RUSIA & 2003 & $\mathrm{x}$ & $\mathrm{X}$ & $\mathrm{X}$ & $\mathrm{X}$ & & 28,219 & $36,900,000$ \\
\hline & SLOVAKIA & 2008 & $\mathrm{x}$ & $\mathrm{X}$ & $\mathrm{X}$ & $\mathrm{X}$ & $\mathrm{X}$ & 6,480 & $2,120,510$ \\
\hline & TAJIKISTAN & 2003 & $\mathrm{x}$ & $\mathrm{X}$ & $\mathrm{X}$ & $\mathrm{x}$ & $\mathrm{x}$ & 4,664 & $1,202,027$ \\
\hline & TURKEY & 2005 & $\mathrm{x}$ & $\mathrm{X}$ & & & & 70,785 & 70,785 \\
\hline & $\begin{array}{l}\text { NO. OF COUNTRIES } \\
\text { TOTAL }\end{array}$ & & 18 & 18 & 15 & 15 & 12 & 174,049 & $72,167,103$ \\
\hline \multirow{3}{*}{ के } & MALDIVES & 2004 & $\mathrm{x}$ & & & & & 1,427 & 25,808 \\
\hline & NEPAL & 2003 & $\mathrm{x}$ & $\mathrm{x}$ & $\mathrm{X}$ & $\mathrm{X}$ & & 442 & 537,722 \\
\hline & $\begin{array}{l}\text { NO. OF COUNTRIES } \\
\text { TOTAL }\end{array}$ & & 2 & 1 & 1 & 1 & & 1,869 & 563,530 \\
\hline \multirow{6}{*}{$\sum_{i=1}^{0}$} & MICRONESIA & 2000 & $\mathrm{x}$ & $\mathrm{x}$ & & & & 12,330 & 12,330 \\
\hline & INDONESIA & 2002 & $\mathrm{x}$ & $\mathrm{x}$ & & & & 104,811 & $28,200,000$ \\
\hline & CAMBODIA & 2004 & $\mathrm{x}$ & $\mathrm{X}$ & $\mathrm{x}$ & $\mathrm{x}$ & & 7,466 & $1,238,972$ \\
\hline & MONGOLIA & 2002 & $\mathrm{x}$ & $\mathrm{X}$ & $\mathrm{X}$ & $\mathrm{X}$ & $\mathrm{X}$ & 2,631 & 403,883 \\
\hline & VIETNAM & 2002 & $\mathrm{x}$ & $\mathrm{x}$ & $\mathrm{X}$ & $\mathrm{x}$ & & 24,502 & $14,800,000$ \\
\hline & $\begin{array}{l}\text { NO. OF COUNTRIES } \\
\text { TOTAL }\end{array}$ & & 5 & 5 & 3 & 3 & 1 & 151,740 & $44,655,185$ \\
\hline \multirow{18}{*}{ 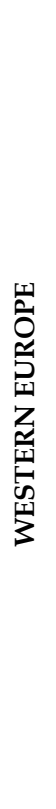 } & AUSTRIA & 2008 & $\mathrm{x}$ & $\mathrm{X}$ & $\mathrm{x}$ & $\mathrm{x}$ & & 5,243 & $3,289,700$ \\
\hline & BELGIUM & 2008 & $\mathrm{x}$ & $\mathrm{x}$ & $\mathrm{x}$ & $x$ & & 5,732 & $4,031,928$ \\
\hline & CYPRUS & 2008 & $\mathrm{x}$ & $\mathrm{x}$ & $\mathrm{x}$ & $\mathrm{x}$ & & 4,091 & 350,609 \\
\hline & GERMANY & 2008 & $\mathrm{x}$ & $\mathrm{x}$ & $\mathrm{x}$ & $\mathrm{x}$ & & 11,324 & $33,800,000$ \\
\hline & DENMARK & 2008 & $\mathrm{x}$ & $\mathrm{X}$ & $\mathrm{X}$ & & & 11,324 & $33,800,000$ \\
\hline & SPAIN & 2008 & $\mathrm{x}$ & $\mathrm{x}$ & $\mathrm{x}$ & $\mathrm{x}$ & & 13,025 & $18,000,000$ \\
\hline & FINLAND & 2008 & $\mathrm{x}$ & $\mathrm{x}$ & $\mathrm{x}$ & $\mathrm{x}$ & & 11,913 & $2,240,843$ \\
\hline & GREECE & 2008 & $\mathrm{x}$ & $\mathrm{x}$ & $\mathrm{x}$ & $\mathrm{x}$ & & 5,820 & $4,113,921$ \\
\hline & IRELAND & 2008 & $\mathrm{x}$ & $\mathrm{X}$ & $\mathrm{x}$ & $\mathrm{x}$ & & 4,124 & $1,671,177$ \\
\hline & ICELAND & 2008 & $\mathrm{x}$ & $\mathrm{x}$ & $\mathrm{x}$ & $\mathrm{x}$ & & 4,079 & 143,664 \\
\hline & ITALY & 2008 & $\mathrm{x}$ & $\mathrm{X}$ & $\mathrm{X}$ & $\mathrm{x}$ & & 18,605 & $21,700,000$ \\
\hline & LUXEMBOURG & 2008 & $\mathrm{x}$ & $\mathrm{X}$ & $\mathrm{X}$ & $\mathrm{x}$ & & 4,310 & 198,882 \\
\hline & NORWAY & 2008 & $\mathrm{x}$ & $\mathrm{X}$ & $\mathrm{X}$ & & & 6,350 & $2,077,142$ \\
\hline & PORTUGAL & 2008 & $\mathrm{x}$ & $\mathrm{X}$ & $\mathrm{X}$ & $\mathrm{x}$ & & 3,966 & $4,012,968$ \\
\hline & SWEDEN & 2008 & $\mathrm{x}$ & $\mathrm{X}$ & $\mathrm{X}$ & & & 8,443 & $4,074,758$ \\
\hline & UNITED KINGDOM & 2008 & $\mathrm{x}$ & $\mathrm{x}$ & $\mathrm{x}$ & $\mathrm{x}$ & & 7,585 & $23,100,000$ \\
\hline & NO. OF COUNTRIES & & 16 & 16 & 16 & 13 & & & \\
\hline & TOTAL & & & & & & & 125,934 & $156,605,592$ \\
\hline
\end{tabular}

Source: Authors' calculations using Household Surveys (World Bank)

Tables $2 \mathrm{a}$ and $2 \mathrm{~b}$ show descriptive statistics by region. Table $2 \mathrm{a}$ presents the descriptive statistics regarding the demographic set of variables; Table $2 b$ presents the job-related variables. In most cases the descriptive statistics are shown for the full set of variables. The descriptive statistics obtained for the more restricted sets 
of variables (that is, those including more comprehensive sets of countries) depict similar results. ${ }^{4}$

Regarding the gender composition of the labor force it is possible to distinguish three groups of regions. First, MENA and SA show more than seventy percent of males on their active labor force; second, SSA have around sixty percent of males; third, ECA and Western Europe have only slightly more males than females; and fourth EAP show slightly less males than females on their labor force. Regarding the urban/rural split and gender composition MENA highlights. While almost half of working males in this region are located in urban areas, it is nine out of ten females who do so. In all other regions of the world the urban/rural split does not differ much between males and females.

Educational differences are also interesting to highlight. SSA, MENA and SA show a high fraction of females with no education or primary incomplete, although in MENA the corresponding percentage of males is even higher. On the other extreme of the educational distribution, in all regions but SA the percentage of females achieving post secondary education surpasses that of males.

The gender differences in marital status and household composition are also salient. In all regions the proportion of married males surpasses that of females. In SSA and SA the proportion of widowed females is around 10\%. In SSA, ECA and Western Europe it is interesting to highlight that also around $10 \%$ of females are divorced. The proportion of never married among working women in MENA is interestingly higher than the corresponding proportion for males. ECA highlights as the region of the world with the lowest presence of children in the workers' households (such indicator cannot be computed for Western Europe). SSA in turn highlights as the region of the world with the highest presence on elderly in the workers' households, slightly higher for males than for females. In all regions of the world the proportion of females living with another labor-income-generator at home is higher than that of males.

The job-related differences by gender, depicted in Table $2 b$ for all regions under analysis, are also salient. Part-time work (defined in this paper as working 20 hours or less per week) is more prevalent among females than males across the globe, but this is especially the case in Western Europe. Also, SSA and SA highlight as having a high proportion of males doing part-time work.

Self-employment is prevalent in SSA both for males and females, but especially for the latter (although it is important to note that this is not possible to identify in

\footnotetext{
${ }^{4}$ Using Kolmogorov-Smirnov tests we conclude at the $90 \%$ confidence that the distributions of characteristics do not differ across the sets of variables, for both males and females. That is, restricting the dataset due to data availability does not bias the sample.
} 
MENA and SA). Regarding occupations and economic sectors, all regions show some degree of segregation by gender but it is ECA the region that shows it the highest occupational segregation. In this region "Professionals and technicians" and "Service workers" are clearly segments with higher female prevalence; contrasting "Administrative personnel and intermediary level" and "Machine operators" which are male-dominated occupations. EAP and Western Europe show the lowest fraction of the labor force working on elementary occupations. Regarding formality, Sub-Saharan Africa show a higher fraction of formal working males than formal working females but in MENA, ECA and EAP the situation is reversed (in SA and Western Europe it is not possible to measure formality). 
Table 2a. Descriptive Statistics by Region -Demographic Characteristics +

\begin{tabular}{|c|c|c|c|c|c|c|c|c|c|c|c|c|}
\hline \multirow[b]{3}{*}{ All } & \multicolumn{2}{|c|}{ SSA } & \multicolumn{2}{|c|}{ MENA } & \multicolumn{2}{|c|}{ ECA } & \multicolumn{2}{|c|}{$\mathbf{S A}^{++}$} & \multicolumn{2}{|c|}{ EAP } & \multicolumn{2}{|c|}{ WESTERN EUROPE ${ }^{++}$} \\
\hline & Male & Female & Male & Female & Male & Female & Male & Female & Male & Female & Male & Female \\
\hline & 62 & 38 & 83 & 17 & 54 & 46 & 77 & 23 & 47 & 53 & 56 & 45 \\
\hline \multicolumn{13}{|l|}{ Age } \\
\hline $15-24$ & 11.0 & 16.2 & 19.8 & 25.2 & 10.9 & 9.1 & 18.6 & 14.0 & 12.5 & 10.3 & 8.3 & 8.4 \\
\hline $25-34$ & 29.3 & 30.7 & 32.4 & 40.0 & 30.5 & 27.1 & 31.0 & 30.4 & 26.9 & 29.7 & 23.1 & 24.0 \\
\hline $35-44$ & 28.0 & 26.5 & 25.9 & 23.7 & 25.0 & 28.3 & 23.4 & 26.9 & 33.7 & 35.7 & 30.5 & 30.8 \\
\hline $45-54$ & 21.1 & 18.6 & 17.0 & 9.6 & 23.2 & 28.3 & 16.8 & 19.0 & 18.7 & 21.1 & 25.5 & 25.6 \\
\hline $55-65$ & 10.6 & 8.1 & 4.8 & 1.4 & 10.4 & 7.2 & 10.2 & 9.7 & 8.3 & 3.2 & 12.7 & 11.3 \\
\hline \multicolumn{13}{|l|}{ Urban } \\
\hline No & 58.4 & 55.3 & 44.4 & 11.1 & 45.8 & 41.4 & 84.6 & 92.1 & 26.8 & 24.4 & 18.7 & 15.8 \\
\hline Yes & 41.6 & 44.7 & 55.6 & 88.9 & 54.2 & 58.6 & 15.4 & 7.9 & 73.2 & 75.6 & 81.3 & 84.2 \\
\hline \multicolumn{13}{|l|}{ Education } \\
\hline None or Primary Incomplete & 21.8 & 33.4 & 18.2 & 9.2 & 2.7 & 2.0 & 71.1 & 92.8 & 5.5 & 2.5 & 7.1 & 5.0 \\
\hline Primary Complete or Secondary Incomplete & 51.6 & 43.1 & 49.4 & 34.3 & 68.8 & 58.8 & 27.9 & 7.2 & 18.3 & 11.6 & 62.9 & 59.8 \\
\hline Secondary Complete & 11.3 & 5.7 & 18.6 & 36.8 & 7.6 & 9.4 & 0.9 & 0.0 & 26.9 & 24.0 & 5.0 & 7.0 \\
\hline Post Secondary & 15.4 & 17.8 & 13.8 & 19.8 & 20.8 & 29.9 & 0.1 & 0.0 & 49.2 & 61.9 & 25.0 & 28.1 \\
\hline \multicolumn{13}{|l|}{ Marital Status } \\
\hline Married or Live together & 78.9 & 65.8 & 68.9 & 44.4 & 66.4 & 63.9 & 88.8 & 82.7 & 77.5 & 68.5 & 60.1 & 56.9 \\
\hline Divorced/Separated & 3.4 & 10.7 & 0.6 & 2.9 & 4.3 & 10.1 & 1.5 & 0.7 & 2.3 & 7.5 & 6.1 & 10.6 \\
\hline Widow/er & 1.4 & 9.2 & 0.4 & 3.0 & 0.9 & 4.4 & 1.7 & 11.1 & 2.3 & 7.7 & 0.7 & 2.3 \\
\hline Single & 16.3 & 14.2 & 30.1 & 49.7 & 28.4 & 21.5 & 8.0 & 5.5 & 18.0 & 16.3 & 33.1 & 30.1 \\
\hline \multicolumn{13}{|l|}{ Presence of children in the household } \\
\hline No & 21.2 & 19.8 & 28.0 & 50.0 & 85.1 & 88.7 & 13.2 & 15.7 & 36.0 & 35.5 & - & . \\
\hline Yes & 78.8 & 80.2 & 72.0 & 50.0 & 14.9 & 11.3 & 86.8 & 84.3 & 64.0 & 64.5 & - & - \\
\hline \multicolumn{13}{|l|}{ Presence of elderly in the household } \\
\hline No & 79.5 & 85.5 & 98.9 & 99.5 & 91.8 & 93.3 & 98.3 & 99.6 & 99.4 & 99.2 & 99.6 & 99.5 \\
\hline Yes & 20.5 & 14.5 & 1.1 & 0.5 & 8.2 & 6.7 & 1.7 & 0.4 & 0.6 & 0.8 & 0.4 & 0.5 \\
\hline \multicolumn{13}{|l|}{ Presence of other member with labor income } \\
\hline No & 46.6 & 33.0 & 57.3 & 33.5 & 28.1 & 23.4 & 63.1 & 41.5 & 25.8 & 24.4 & 39.3 & 31.5 \\
\hline Yes & 53.4 & 67.0 & 42.7 & 66.5 & 71.9 & 76.6 & 36.9 & 58.5 & 74.2 & 75.6 & 60.7 & 68.5 \\
\hline Observations (Weighted) & $12,799,673$ & $7,931,462$ & $2,057,650$ & 433,602 & $13,578,354$ & $11,756,044$ & 412,112 & 125,610 & 191,539 & 212,344 & $64,750,428$ & $51,948,315$ \\
\hline Observations (Unweighted) & 20,304 & 13,913 & 24,446 & 8,232 & 32,490 & 28,694 & 344 & 98 & 1,249 & 1,382 & 21,101 & 13,498 \\
\hline Number of Countries & & 6 & & 2 & & 12 & & 1 & & 1 & & 13 \\
\hline
\end{tabular}

Source: Authors' calculations using Household Surveys (World Bank)

+ For SA and Western Europe results are reported using the Economic sector Set, given the fact that social security is not a proper control for informality. 
Table 2b. Descriptive Statistics by Region - Job Related Characteristics

\begin{tabular}{|c|c|c|c|c|c|c|c|c|c|c|c|c|}
\hline \multirow[b]{3}{*}{ All } & \multicolumn{2}{|c|}{ SSA } & \multicolumn{2}{|c|}{ MENA } & \multicolumn{2}{|c|}{ ECA } & \multicolumn{2}{|c|}{ SA } & \multicolumn{2}{|c|}{ EAP } & \multicolumn{2}{|c|}{ WESTERN EUROPE } \\
\hline & Male & Female & Male & Female & Male & Female & Male & Female & Male & Female & Male & Female \\
\hline & 62 & 38 & 83 & 17 & 54 & 46 & 77 & 23 & 47 & 53 & 56 & 45 \\
\hline \multicolumn{13}{|l|}{ Hours of work per week } \\
\hline $0-20$ Hours & 12.6 & 15.9 & 4.3 & 7.0 & 2.1 & 4.3 & 14.6 & 18.7 & 1.3 & 1.3 & 2.5 & 17.9 \\
\hline 21-40 Hours & 34.1 & 38.9 & 26.5 & 27.8 & 65.9 & 77.1 & 32.9 & 45.4 & 58.9 & 67.6 & 53.2 & 62.9 \\
\hline More than 40 Hours & 53.3 & 45.2 & 69.2 & 65.2 & 32.1 & 18.6 & 52.4 & 36.0 & 39.8 & 31.1 & 44.4 & 19.3 \\
\hline \multicolumn{13}{|l|}{ Type of Employment } \\
\hline Employee & 44.1 & 27.0 & 100.0 & 100.0 & 97.6 & 98.1 & 100.0 & 100.0 & 98.4 & 98.5 & 84.4 & 91.7 \\
\hline Employer & 3.6 & 2.8 & - & - & 0.3 & 0.2 & - & - & 0.4 & 0.9 & 5.0 & 2.0 \\
\hline Self-Employed & 52.2 & 70.3 & 0.0 & 0.0 & 2.0 & 1.7 & - & - & 1.2 & 0.6 & 10.6 & 6.3 \\
\hline \multicolumn{13}{|l|}{ Occupation } \\
\hline Professionals and technicians & 12.2 & 8.3 & 14.6 & 26.7 & 22.5 & 38.5 & 0.6 & 2.4 & 30.4 & 46.3 & 28.7 & 36.0 \\
\hline $\begin{array}{l}\text { Directors and upper } \\
\text { management }\end{array}$ & 6.5 & 4.8 & 10.6 & 2.4 & 6.3 & 4.0 & & & 9.5 & 4.5 & 10.0 & 5.5 \\
\hline $\begin{array}{l}\text { Administrative personal and } \\
\text { intermediary level }\end{array}$ & 14.8 & 12.0 & 19.4 & 26.8 & 30.8 & 19.8 & 33.0 & 5.5 & 20.7 & 20.9 & 31.2 & 24.2 \\
\hline Service workers & 12.9 & 23.8 & 16.4 & 7.0 & 8.8 & 16.8 & 1.5 & 0.0 & 11.9 & 15.8 & 7.7 & 20.5 \\
\hline Skilled agriculture & 21.3 & 21.9 & 4.8 & 0.5 & 1.5 & 1.1 & 0.6 & 0.5 & 1.7 & 1.3 & 2.7 & 1.1 \\
\hline Machine operators & 4.6 & 0.6 & 8.2 & 17.4 & 18.1 & 6.1 & 2.7 & 0.0 & 17.7 & 3.1 & 11.3 & 2.3 \\
\hline Armed forces & 0.5 & 0.1 & 0.0 & 0.0 & 0.0 & 0.0 & - & - & 0.0 & 0.0 & - & - \\
\hline Elementary occupations & 27.2 & 28.5 & 25.8 & 19.2 & 12.0 & 13.6 & 61.6 & 91.6 & 8.2 & 8.0 & 8.4 & 10.4 \\
\hline \multicolumn{13}{|l|}{ Economic Sector } \\
\hline $\begin{array}{l}\text { Agriculture, Hunting, } \\
\text { Forestry and Fishing }\end{array}$ & 45.0 & 44.4 & 14.1 & 2.0 & 7.6 & 5.5 & 57.0 & 27.5 & 3.5 & 2.3 & 3.6 & 1.7 \\
\hline Mining and Quarryng & 9.7 & 4.5 & 2.5 & 0.4 & - & - & 12.0 & 12.2 & 6.9 & 3.6 & - & - \\
\hline Manufacturing & 14.6 & 13.1 & 9.4 & 41.4 & 33.8 & 21.2 & 5.6 & 15.5 & 5.5 & 9.1 & 25.1 & 11.4 \\
\hline $\begin{array}{l}\text { Electricity, Gas and Water } \\
\text { supply }\end{array}$ & 0.9 & 0.2 & 17.0 & 0.8 & - & - & 5.6 & 9.5 & 5.5 & 2.2 & - & - \\
\hline Construction & 2.7 & 0.2 & 10.4 & 2.3 & 11.9 & 1.5 & 2.9 & 9.7 & 7.1 & 2.7 & 12.8 & 1.9 \\
\hline $\begin{array}{l}\text { Wholesale and Retail, Trade } \\
\text { and Hotels and Restaurants }\end{array}$ & 11.9 & 27.2 & 7.8 & 7.6 & 12.2 & 19.6 & 5.8 & 9.9 & 5.2 & 9.9 & 16.3 & 20.7 \\
\hline Transport, Storage & 4.7 & 0.2 & 19.4 & 4.9 & 9.8 & 4.4 & 2.0 & 5.7 & 11.6 & 4.0 & 8.1 & 3.6 \\
\hline Finance and Business Services & 2.0 & 1.2 & 2.1 & 4.6 & 1.7 & 3.8 & 2.7 & 6.0 & 3.7 & 4.2 & 3.8 & 4.7 \\
\hline Communal Services & 6.4 & 5.3 & 17.2 & 35.8 & 20.5 & 40.8 & 3.6 & 3.0 & 47.0 & 58.6 & 25.3 & 47.0 \\
\hline Others not well specified & 2.1 & 3.6 & 0.1 & 0.1 & 2.5 & 3.2 & 2.9 & 1.2 & 4.0 & 3.5 & 5.0 & 9.1 \\
\hline \multicolumn{13}{|l|}{ Formality } \\
\hline No & 78.0 & 86.8 & 52.5 & 10.6 & 8.1 & 6.9 & - & - & 12.0 & 10.4 & - & - \\
\hline Yes & 22.0 & 13.2 & 47.5 & 89.4 & 91.9 & 93.1 & - & - & 88.0 & 89.6 & - & - \\
\hline Observations (Weighted) & $12,799,673$ & $7,931,462$ & $2,057,650$ & 433,602 & $13,578,354$ & $11,756,044$ & 412,112 & 125,610 & 191,539 & 212,344 & $64,750,428$ & $51,948,315$ \\
\hline Observations (Unweighted) & 20,304 & 13,913 & 24,446 & $\mathbf{8 , 2 3 2}$ & 32,490 & 28,694 & 344 & 98 & 1,249 & 1,382 & 21,101 & 13,498 \\
\hline Number of Countries & & 6 & & 2 & & 12 & & 1 & & 1 & & 13 \\
\hline
\end{tabular}

Source: Authors' calculations using Household Surveys (World Bank) 
Tables $3 a$ and $3 b$ show additional descriptive statistics. In this case these statistics are earnings averages for different segments of the labor markets. As before, the first table uses the demographic set of variables and the second the jobrelated characteristics. Both tables correspond to measures of hourly labor earnings, normalized such that the average of females' earnings in each region is set equal to 100 .

SA highlights as the region with the highest earnings disparities as males earn on average $48 \%$ more than females. On the other extreme are EAP and MENA with gender earnings gaps of $10 \%$ and $8 \%$ of average females' earnings respectively. Note that these are simple comparison of average earnings for all working males and females. These gaps are not taking into account the gender differences in observable characteristics yet. That will be analyzed in the next section.

The earnings pattern over the life cycle shows no surprise. Younger workers (15$24)$ tend to earn less than prime-agers. When getting close to retirement age (5565), females' earnings decrease more than those of males. The earnings patterns with respect to education show no surprises as well. Higher educated workers earn more than those with lower education. The gender differences across those patterns, however, differ (and this will be analyzed latter after the earnings gaps decompositions).

Individuals' earnings in urban areas tend to be higher than those in rural areas. Married males tend to earn higher than the rest of the population. Those with no elderly at home tend to earn higher than their counterparts with at least one elderly at home. The only exception to that happens among females in SSA (recall that SSA is also the region of the world where workers tend to live more with their elderly relatives).

Regarding occupations, is no surprise that "Directors and upper management" and "Professionals and technicians" tend to have higher earnings than those at other occupations. Interestingly, "Armed forces" are also a high-paying occupation for women in Sub-Saharan Africa. This may reflect that females who join the army, generally, do not do so in lower-hierarchy positions. Regarding economic sectors, it is also no surprising to verify that finance and business services are at the top earnings. 
Table 3a. Earnings Distribution by Region - Demographic Characteristics

\begin{tabular}{|c|c|c|c|c|c|c|c|c|c|c|c|c|}
\hline & \multicolumn{2}{|c|}{ SSA } & \multicolumn{2}{|c|}{ MENA } & \multicolumn{2}{|c|}{ ECA } & \multicolumn{2}{|c|}{ SA } & \multicolumn{2}{|c|}{ EAP } & \multicolumn{2}{|c|}{ WESTERN EUROPE } \\
\hline & Male & Female & Male & Female & Male & Female & Male & Female & Male & Female & Male & Female \\
\hline All & 135 & 100 & 108 & 100 & 118 & 100 & 148 & 100 & 110 & 100 & 123 & 100 \\
\hline \multicolumn{13}{|l|}{ Age } \\
\hline $15-24$ & 99.0 & 70.5 & 88 & 48 & 80.4 & 67.5 & 164.1 & 245.3 & 101.6 & 90.6 & 62.9 & 57.9 \\
\hline $25-34$ & 136.1 & 104.9 & 102 & 106 & 114.5 & 96.1 & 143.6 & 89.2 & 105.6 & 103.8 & 105.4 & 90.8 \\
\hline $35-44$ & 135.2 & 109.9 & 116 & 130 & 132.1 & 107.1 & 141.1 & 72.7 & 113.9 & 100.0 & 130.3 & 104.9 \\
\hline $45-54$ & 139.9 & 103.9 & 128 & 134 & 120.7 & 105.6 & 148.0 & 67.8 & 117.9 & 99.6 & 140.2 & 112.2 \\
\hline $55-65$ & 154.3 & 98.9 & 126 & 117 & 125.8 & 105.4 & 142.9 & 63.4 & 98.5 & 97.7 & 140.6 & 110.1 \\
\hline \multicolumn{13}{|l|}{ Urban } \\
\hline No & 120.5 & 89.6 & 101 & 67 & 101.2 & 84.5 & 137.3 & 98.5 & 84.7 & 80.6 & 103.4 & 89.9 \\
\hline Yes & 154.1 & 112.9 & 114 & 104 & 131.8 & 111.0 & 203.3 & 117.6 & 118.8 & 106.2 & 127.3 & 101.9 \\
\hline \multicolumn{13}{|l|}{ Education } \\
\hline None or Primary Incomplete & 106.8 & 79.6 & 99 & 48 & 73.3 & 55.5 & 139.8 & 83.1 & 92.4 & 96.8 & 86.4 & 67.5 \\
\hline Primary Complete or Secondary Incomplete & 119.4 & 102.2 & 91 & 55 & 101.6 & 80.8 & 159.6 & 317.5 & 91.9 & 72.1 & 105.8 & 85.9 \\
\hline Secondary Complete & 192.5 & 129.0 & 100 & 87 & 107.2 & 88.9 & 311.1 & 0.0 & 88.5 & 78.9 & 121.6 & 103.6 \\
\hline Post Secondary & 181.8 & 123.7 & 195 & 226 & 181.2 & 144.3 & 623.3 & 0.0 & 129.7 & 113.5 & 176.1 & 134.8 \\
\hline \multicolumn{13}{|l|}{ Marital Status } \\
\hline Married or Live together & 144.3 & 108.8 & 119 & 138 & 127.3 & 100.5 & 147.5 & 99.2 & 112.4 & 99.6 & 135.8 & 103.9 \\
\hline Divorced/Separated & 89.6 & 90.6 & 88 & 101 & 113.9 & 114.3 & 102.5 & 59.9 & 88.2 & 105.5 & 133.0 & 102.4 \\
\hline Widow/er & 110.9 & 88.4 & 86 & 78 & 101.4 & 94.2 & 126.8 & 71.6 & 75.8 & 96.7 & 119.4 & 99.5 \\
\hline Single & 98.3 & 73.8 & 84 & 67 & 96.7 & 92.9 & 160.6 & 174.5 & 104.7 & 100.9 & 97.3 & 91.8 \\
\hline \multicolumn{13}{|l|}{ Presence of children in the household } \\
\hline No & 127.8 & 122.2 & 101 & 90 & 118.6 & 101.5 & 142.9 & 122.5 & 117.5 & 109.1 & - & - \\
\hline Yes & 136.3 & 94.5 & 111 & 110 & 113.3 & 88.5 & 148.2 & 95.8 & 105.2 & 95.0 & - & - \\
\hline \multicolumn{13}{|l|}{ Presence of elderly in the household } \\
\hline No & 141.7 & 97.6 & 108 & 100 & 118.7 & 100.3 & 148.0 & 100.0 & 109.7 & 100.2 & 122.8 & 100.0 \\
\hline Yes & 106.6 & 114.1 & 153 & 78 & 107.2 & 96.4 & 119.0 & 106.5 & 89.1 & 79.2 & 123.2 & 92.1 \\
\hline \multicolumn{13}{|l|}{ Presence of other member with labor income } \\
\hline No & 128.6 & 107.1 & 110 & 92 & 121.9 & 106.7 & 154.5 & 141.1 & 97.7 & 94.8 & 126.7 & 105.1 \\
\hline Yes & 106.6 & 114.1 & 153 & 78 & 107.2 & 96.4 & 119.0 & 106.5 & 89.1 & 79.2 & 123.2 & 92.1 \\
\hline
\end{tabular}


Table 3b. Earnings Distribution by Region - Job Related Characteristics

\begin{tabular}{|c|c|c|c|c|c|c|c|c|c|c|c|c|}
\hline & \multicolumn{2}{|c|}{ SSA } & \multicolumn{2}{|c|}{ MENA } & \multicolumn{2}{|c|}{ ECA } & \multicolumn{2}{|c|}{ SA } & \multicolumn{2}{|c|}{ EAP } & \multicolumn{2}{|c|}{ WESTERN EUROPE } \\
\hline & Male & Female & Male & Female & Male & Female & Male & Female & Male & Female & Male & Female \\
\hline All & 135 & 100 & 108 & 100 & 118 & 100 & 148 & 100 & 110 & 100 & 123 & 100 \\
\hline \multicolumn{13}{|l|}{ Hours of work per week } \\
\hline $0-20$ Hours & 339.4 & 233.4 & 372 & 369 & 275.2 & 188.9 & 329.3 & 266.8 & 280.8 & 242.1 & 228.1 & 103.2 \\
\hline 21-40 Hours & 123.3 & 85.0 & 123 & 137 & 118.6 & 100.1 & 144.0 & 75.7 & 117.0 & 106.9 & 118.4 & 100.2 \\
\hline More than 40 Hours & 93.3 & 66.1 & 86 & 55 & 105.9 & 79.2 & 98.9 & 44.0 & 93.1 & 79.3 & 122.2 & 96.5 \\
\hline \multicolumn{13}{|l|}{ Type of Employment } \\
\hline Employee & 108.2 & 98.4 & 108 & 100 & 117.6 & 100.2 & 147.5 & 100.0 & 109.6 & 99.5 & 121.9 & 99.9 \\
\hline Employer & 475.7 & 171.7 & - & - & 125.9 & 97.2 & - & - & 156.9 & 142.8 & 170.0 & 130.8 \\
\hline Self-Employed & 133.0 & 97.8 & 0 & 0 & 127.6 & 88.7 & - & - & 93.4 & 122.3 & 107.7 & 90.9 \\
\hline \multicolumn{13}{|l|}{ Occupation } \\
\hline Professionals and technicians & 210.9 & 128.7 & 183 & 212 & 158.5 & 128.0 & 234.9 & 719.4 & 130.2 & 111.6 & 161.9 & 128.7 \\
\hline Directors and upper management & 158.8 & 149.5 & 117 & 162 & 199.5 & 170.2 & - & - & 144.0 & 129.6 & 168.5 & 120.4 \\
\hline $\begin{array}{l}\text { Administrative personnal and intermediary } \\
\text { level }\end{array}$ & 139.7 & 117.8 & 102 & 68 & 102.5 & 89.2 & 171.6 & 208.9 & 101.1 & 96.5 & 103.5 & 94.9 \\
\hline Service workers & 150.6 & 114.7 & 103 & 53 & 97.4 & 73.5 & 291.2 & 0.0 & 88.3 & 83.1 & 96.7 & 72.1 \\
\hline Skilled agricultura & 97.1 & 72.0 & 54 & 36 & 68.9 & 55.7 & 188.1 & 59.9 & 99.1 & 82.5 & 69.9 & 56.4 \\
\hline Machine operators & 109.8 & 92.3 & 99 & 49 & 102.7 & 77.8 & 165.8 & 0.0 & 100.7 & 98.1 & 97.4 & 74.3 \\
\hline Armed forces & 96.4 & 233.9 & - & - & 0.0 & 0.0 & - & - & 0.0 & 0.0 & - & - \\
\hline Elementary occupations & 118.1 & 84.6 & 84 & 47 & 81.0 & 62.0 & 129.0 & 77.3 & 66.9 & 62.7 & 82.0 & 67.3 \\
\hline \multicolumn{13}{|l|}{ Economic Sector } \\
\hline Agriculture, Hunting, Forestry and Fishing & 123.9 & 91.9 & 65 & 50 & 84.3 & 62.2 & 130.1 & 66.3 & 93.5 & 81.0 & 69.7 & 60.3 \\
\hline Mining and Quarryng & 121.4 & 69.1 & 108 & 89 & - & - & 177.6 & 77.2 & 151.8 & 161.5 & - & - \\
\hline Manufacturing & 83.7 & 94.0 & 76 & 52 & 113.7 & 90.8 & 129.0 & 67.8 & 97.4 & 83.7 & 123.2 & 96.8 \\
\hline Electricity, Gas and Water supply & 198.3 & 228.9 & 118 & 88 & - & - & 135.9 & 68.8 & 123.6 & 139.9 & - & - \\
\hline Construction & 93.1 & 75.1 & 145 & 73 & 101.2 & 111.2 & 193.0 & 106.7 & 98.0 & 117.3 & 100.6 & 106.6 \\
\hline $\begin{array}{l}\text { Wholesale and Retail, Trade and Hotels and } \\
\text { Restaurants }\end{array}$ & 181.9 & 118.8 & 83 & 61 & 109.0 & 81.4 & 198.9 & 145.0 & 133.9 & 91.3 & 98.3 & 76.7 \\
\hline Transport, Storage & 94.3 & 96.7 & 96 & 112 & 122.0 & 109.9 & 226.7 & 135.0 & 115.0 & 111.3 & 113.4 & 97.3 \\
\hline Finance and Business Services & 178.9 & 130.9 & 104 & 114 & 212.2 & 143.5 & 140.5 & 346.8 & 171.8 & 113.0 & 211.2 & 130.2 \\
\hline Communal Services & 256.7 & 106.8 & 156 & 165 & 142.0 & 114.0 & 112.5 & 39.7 & 99.0 & 96.1 & 148.3 & 112.9 \\
\hline Others not well specified & 207.0 & 91.3 & 118 & 154 & 118.2 & 91.2 & 270.6 & 99.9 & 91.4 & 115.8 & 114.3 & 81.8 \\
\hline \multicolumn{13}{|l|}{ Formality } \\
\hline No & 132.9 & 95.2 & 108 & 73 & 116.9 & 102.9 & - & - & 93.6 & 74.4 & - & - \\
\hline Yes & 140.1 & 131.2 & 109 & 103 & 117.9 & 99.8 & - & - & 111.8 & 103.0 & - & - \\
\hline
\end{tabular}

Source: Authors' calculations using Household Surveys (World Bank) 


\section{Gender Earnings Gap Decompositions}

Tables $4 \mathrm{a}$ and $4 \mathrm{~b}$ show the decompositions for the gender gaps in hourly earnings (at the main occupation), measured as a percentage of the average females' earnings. SSA, MENA and ECA are shown in Table 4a, while SA, EAP and Western Europe are in Table 5b. The structure of the tables is the same across regions. The components of the gender earnings gaps are shown in columns (labeled as Delta 0, Delta M, Delta F and Delta X), together with the percentages of males and females in the common support (labeled as CSF and CSM). ${ }^{5}$

The matching variables that are sequentially added are shown as consecutive lines. First, the "Demographic set" of variables is added: age, urban status, education, marital status, presence of child in the household, presence of an elder in the household and presence of other income-generator in the household (the first and obvious matching variable within the pooled data set is "country"). As mentioned, these are sequentially added as matching variables to measure the extent to which the observed gender earnings gaps can be attributed to gender differences in observed characteristics. On top of the "Demographic set" some jobrelated variables are added, but with replacement. That is, first the number of hours per week is added as a matching variable to the "Demographic set"; then the type of employment variable replaces the number of hour per week as a matching variable; then the occupation variable takes the place type of employment and so on with economic sector and formality. Last, the "All variables" line includes all demographic and job-related variables in the matching.

It can be noted that the most comprehensive set of matching variables is the one that shows the lowest measures of common support for both males and females. These are particularly low for SA. This is a common feature of all non-parametric methods (the curse of dimensionality). The inclusion of a comprehensive set of variables may constraint the comparison of males and females to a small (and perhaps non-representative) set of individuals. For that reason, the discussion of the results below will be done considering the demographic set of variables first and all variables afterwards.

In ECA, EAP and Western Europe, the gender earnings gap that remains after matching on demographic characteristics (that is, after comparing males and females with the same observable characteristics regarding the demographic set) are higher than their corresponding original earnings gap (the one that does not account for gender differences in characteristics). This is also the case for the LAC

\footnotetext{
${ }^{5}$ See Ñopo (2008) for a detailed description of the components and the common supports.
} 
region (Atal et al., 2009). Women show observable characteristics that would make them more attractable to the labor markets (and hence, better paid), but this is actually not the case. In the other three regions under analysis, SSA, MENA and SA, the unexplained gender earnings gap that remain after matching on demographic characteristics are below their corresponding original gap.

When analyzing the role of each particular variable on the explanation of the earnings gaps, it is interesting to note that age moves down the unexplained wage gap in MENA, reflecting that males tend to inhabit the prime-age segments of the distribution in greater proportion than women. The inclusion of education as a matching variable moves up the counterfactual earnings gaps in MENA, ECA and EAP, reflecting that higher school achievements for females are not necessarily compensated in the labor markets. In contrast, the inclusion of education moves down the counterfactual earnings gap in SA. Marital status is a variable that substantially contributes to the explanation of the earnings gap. The inclusion of such variable in the matching reduces the counterfactual earnings gap in SSA, SA and EAP.

The further inclusion of job-related characteristics move the unexplained component of the earnings gaps up and down, with variability depending on the variable to include on the matching and the region of the world. The inclusion of hours of work per week moves up the counterfactual earnings gaps in all regions under analysis. Including type of employment leaves the gap unaltered with respect to the demographic set in all regions but SSA where it drops. Adding occupation as a matching variable increases the counterfactual gap in SSA in SA leaving it almost unaltered in the rest of the regions. In no region, however, the unexplained gender earnings gaps show a reduction after introducing occupation as a matching variable. This apparently paradoxical result, which has also been found for Latin America, suggest that the reduction of gender occupational segregation is a wrong target when trying to reduce gender earnings disparities (Calonico and Nopo, 2009). A slightly similar story can be depicted for economic sectors. The inclusion of formality, in those regions where the data allows it, leaves the counterfactual earnings gap almost unaltered. All in all, the inclusion of all jobrelated characteristics moves the unexplained component of the earnings gaps down in two regions (SA and Western Europe) and up in the other four (SSA, MENA, ECA and EAP).

A related feature is that the Delta $\mathrm{F}$ and Delta $\mathrm{M}$ components of the earnings gap also have the potential to increase. Delta $M$, the component of the earnings gap that can be attributed to the existence of certain combination of observable characteristics to which males reach but females do not, is positive in two regions 
(SSA and SA), negative in MENA and statistically zero the other regions. Females in SSA and SA suffer from a sort of glass-ceiling or barriers to the access to certain well paid segments of the labor markets which males can access. Interestingly, the same two regions show display a negative measure of Delta F, suggesting that there are also some other well paid segments of the labor markets to which females access and males not. The access barriers in these two regions work for both, males and females, but females suffer from barriers that imply higher earnings limitations for them. Regarding Delta F as well it is interesting to note that EAP and to a lesser extent Western Europe display a positive component. This may be an indication of the existence of certain females' confinements within the labor markets with earnings that are below the average of the rest of the markets. 


\section{Table 4a. Gender Earnings Gaps Decompositions by Region}

\begin{tabular}{|c|c|c|c|c|c|c|c|}
\hline \multicolumn{8}{|c|}{ SSA } \\
\hline & & \multicolumn{6}{|c|}{ Delta $=34.50 \%$} \\
\hline & & Delta 0 & Delta $M$ & Delta F & Delta X & CSM & CSF \\
\hline \multirow{8}{*}{ 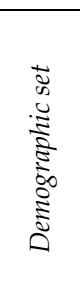 } & Country & $37.18 \%$ & $0.00 \%$ & $0.00 \%$ & $-2.68 \%$ & $100.00 \%$ & $100.00 \%$ \\
\hline & + Age & $33.96 \%$ & $0.00 \%$ & $0.00 \%$ & $0.54 \%$ & $100.00 \%$ & $100.00 \%$ \\
\hline & + Urban & $36.99 \%$ & $0.00 \%$ & $0.00 \%$ & $-2.49 \%$ & $100.00 \%$ & $100.00 \%$ \\
\hline & + Education & $34.83 \%$ & $0.30 \%$ & $-0.15 \%$ & $-0.48 \%$ & $99.15 \%$ & $99.95 \%$ \\
\hline & + Marital Status & $25.80 \%$ & $-0.35 \%$ & $-0.20 \%$ & $9.25 \%$ & $96.90 \%$ & $98.22 \%$ \\
\hline & + Presence of child in the household & $30.09 \%$ & $-0.54 \%$ & $-0.56 \%$ & $5.52 \%$ & $95.94 \%$ & $95.61 \%$ \\
\hline & + Presence of older in the household & $28.72 \%$ & $-0.92 \%$ & $0.08 \%$ & $6.62 \%$ & $95.37 \%$ & $93.93 \%$ \\
\hline & + Presence of other member with income in the household & $28.85 \%$ & $-1.03 \%$ & $0.79 \%$ & $5.90 \%$ & $92.63 \%$ & $90.67 \%$ \\
\hline \multirow{6}{*}{ 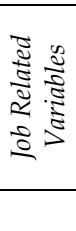 } & \& Hours of work per week & $39.49 \%$ & $0.44 \%$ & $-0.10 \%$ & $-5.32 \%$ & $85.08 \%$ & $82.52 \%$ \\
\hline & \& Type of Employment & $17.81 \%$ & $8.10 \%$ & $-0.16 \%$ & $8.76 \%$ & $88.48 \%$ & $87.68 \%$ \\
\hline & \& Occupation & $37.96 \%$ & $0.04 \%$ & $2.06 \%$ & $-5.56 \%$ & $74.62 \%$ & $79.69 \%$ \\
\hline & \& Economic Sector & $45.57 \%$ & $0.88 \%$ & $1.25 \%$ & $-13.19 \%$ & $73.13 \%$ & $79.64 \%$ \\
\hline & \& Formality & $27.51 \%$ & $-1.14 \%$ & $1.06 \%$ & $7.08 \%$ & $89.05 \%$ & $89.22 \%$ \\
\hline & All Variables & $31.02 \%$ & $16.62 \%$ & $-9.36 \%$ & $-3.78 \%$ & $46.50 \%$ & $55.38 \%$ \\
\hline \multicolumn{8}{|c|}{ MENA } \\
\hline & & \multicolumn{6}{|c|}{ Delta $=8.25 \%$} \\
\hline & & Delta 0 & Delta $M$ & Delta $F$ & Delta X & CSM & CSF \\
\hline \multirow{8}{*}{ 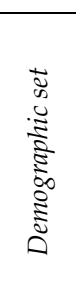 } & Country & $6.08 \%$ & $0.00 \%$ & $0.00 \%$ & $2.17 \%$ & $100.00 \%$ & $100.00 \%$ \\
\hline & + Age & $-3.74 \%$ & $0.00 \%$ & $0.00 \%$ & $11.98 \%$ & $100.00 \%$ & $100.00 \%$ \\
\hline & + Urban & $-0.46 \%$ & $-0.04 \%$ & $0.00 \%$ & $8.75 \%$ & $98.47 \%$ & $100.00 \%$ \\
\hline & + Education & $4.92 \%$ & $0.33 \%$ & $0.00 \%$ & $3.00 \%$ & $94.56 \%$ & $100.00 \%$ \\
\hline & + Marital Status & $3.87 \%$ & $1.31 \%$ & $0.11 \%$ & $2.95 \%$ & $87.81 \%$ & $99.34 \%$ \\
\hline & + Presence of child in the household & $3.88 \%$ & $0.92 \%$ & $0.11 \%$ & $3.35 \%$ & $83.58 \%$ & $97.76 \%$ \\
\hline & + Presence of older in the household & $3.80 \%$ & $1.35 \%$ & $0.10 \%$ & $3.00 \%$ & $82.84 \%$ & $97.44 \%$ \\
\hline & + Presence of other member with income in the household & $6.09 \%$ & $0.60 \%$ & $0.06 \%$ & $1.49 \%$ & $73.92 \%$ & $96.39 \%$ \\
\hline \multirow{6}{*}{ 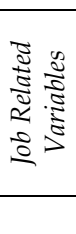 } & \& Hours of work per week & $12.96 \%$ & $3.13 \%$ & $-0.50 \%$ & $-7.35 \%$ & $65.15 \%$ & $94.32 \%$ \\
\hline & \& Type of Employment & $6.09 \%$ & $0.60 \%$ & $0.06 \%$ & $1.49 \%$ & $73.92 \%$ & $96.39 \%$ \\
\hline & \& Occupation & $7.21 \%$ & $2.74 \%$ & $1.80 \%$ & $-3.50 \%$ & $52.63 \%$ & $91.94 \%$ \\
\hline & \& Economic Sector & $7.90 \%$ & $3.18 \%$ & $2.88 \%$ & $-5.72 \%$ & $46.24 \%$ & $90.29 \%$ \\
\hline & \& Formality & $6.92 \%$ & $1.99 \%$ & $0.27 \%$ & $-0.94 \%$ & $68.28 \%$ & $95.44 \%$ \\
\hline & All Variables & $12.24 \%$ & $-5.40 \%$ & $3.55 \%$ & $-2.15 \%$ & $25.50 \%$ & $77.68 \%$ \\
\hline \multicolumn{8}{|c|}{ ECA } \\
\hline & & \multicolumn{6}{|c|}{ Delta $=\mathbf{1 7 . 8 0} \%$} \\
\hline & & Delta 0 & Delta $M$ & Delta F & Delta X & CSM & CSF \\
\hline \multirow{8}{*}{ 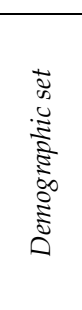 } & Country & $17.88 \%$ & $0.00 \%$ & $0.00 \%$ & $-0.08 \%$ & $100.00 \%$ & $100.00 \%$ \\
\hline & + Age & $19.00 \%$ & $0.00 \%$ & $0.00 \%$ & $-1.19 \%$ & $100.00 \%$ & $100.00 \%$ \\
\hline & + Urban & $19.99 \%$ & $0.02 \%$ & $0.00 \%$ & $-2.21 \%$ & $99.92 \%$ & $100.00 \%$ \\
\hline & + Education & $26.67 \%$ & $-0.09 \%$ & $0.00 \%$ & $-8.78 \%$ & $99.61 \%$ & $99.97 \%$ \\
\hline & + Marital Status & $25.55 \%$ & $-0.26 \%$ & $0.12 \%$ & $-7.61 \%$ & $99.01 \%$ & $97.88 \%$ \\
\hline & + Presence of child in the household & $25.49 \%$ & $-0.23 \%$ & $0.13 \%$ & $-7.59 \%$ & $98.89 \%$ & $97.59 \%$ \\
\hline & + Presence of older in the household & $25.38 \%$ & $-0.21 \%$ & $0.16 \%$ & $-7.53 \%$ & $98.62 \%$ & $97.30 \%$ \\
\hline & + Presence of other member with income in the household & $25.74 \%$ & $-0.22 \%$ & $-0.98 \%$ & $-6.74 \%$ & $97.71 \%$ & $96.04 \%$ \\
\hline \multirow{6}{*}{ 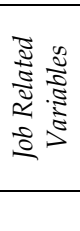 } & \& Hours of work per week & $29.72 \%$ & $0.41 \%$ & $-2.05 \%$ & $-10.28 \%$ & $94.32 \%$ & $92.13 \%$ \\
\hline & \& Type of Employment & $25.68 \%$ & $-0.18 \%$ & $-0.91 \%$ & $-6.78 \%$ & $96.90 \%$ & $95.67 \%$ \\
\hline & \& Occupation & $25.05 \%$ & $-0.57 \%$ & $-0.42 \%$ & $-6.26 \%$ & $88.07 \%$ & $87.89 \%$ \\
\hline & \& Economic Sector & $27.07 \%$ & $-0.55 \%$ & $-1.20 \%$ & $-7.51 \%$ & $80.40 \%$ & $78.67 \%$ \\
\hline & \& Formality & $25.55 \%$ & $-0.36 \%$ & $-0.91 \%$ & $-6.48 \%$ & $96.86 \%$ & $95.69 \%$ \\
\hline & All Variables & $27.49 \%$ & $-0.38 \%$ & $-0.12 \%$ & $-9.18 \%$ & $47.28 \%$ & $52.87 \%$ \\
\hline
\end{tabular}

Source: Authors' calculations using Household Surveys (World Bank) 


\section{Table 4b. Gender Earnings Gaps Decompositions by Region}

\begin{tabular}{|c|c|c|c|c|c|c|c|}
\hline \multicolumn{8}{|c|}{ SA } \\
\hline & & \multicolumn{6}{|c|}{ Delta $=47.51 \%$} \\
\hline & & Delta 0 & Delta $M$ & Delta F & Delta X & CSM & CSF \\
\hline \multirow{8}{*}{ 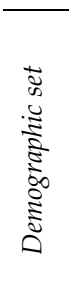 } & Country & $47.51 \%$ & $0.00 \%$ & $0.00 \%$ & $0.00 \%$ & $100.00 \%$ & $100.00 \%$ \\
\hline & + Age & $46.58 \%$ & $0.00 \%$ & $0.00 \%$ & $0.93 \%$ & $100.00 \%$ & $100.00 \%$ \\
\hline & + Urban & $42.33 \%$ & $1.82 \%$ & $0.00 \%$ & $3.36 \%$ & $95.63 \%$ & $100.00 \%$ \\
\hline & + Education & $33.04 \%$ & $6.55 \%$ & $0.00 \%$ & $7.92 \%$ & $78.27 \%$ & $100.00 \%$ \\
\hline & + Marital Status & $28.05 \%$ & $8.53 \%$ & $0.31 \%$ & $10.62 \%$ & $72.82 \%$ & $98.73 \%$ \\
\hline & + Presence of child in the household & $25.82 \%$ & $10.34 \%$ & $0.65 \%$ & $10.69 \%$ & $70.20 \%$ & $97.62 \%$ \\
\hline & + Presence of older in the household & $28.51 \%$ & $9.94 \%$ & $1.21 \%$ & $7.85 \%$ & $68.64 \%$ & $96.90 \%$ \\
\hline & + Presence of other member with income in the household & $21.38 \%$ & $13.15 \%$ & $4.03 \%$ & $8.95 \%$ & $60.59 \%$ & $88.00 \%$ \\
\hline \multirow{5}{*}{ 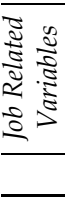 } & \& Hours of work per week & $28.64 \%$ & $11.38 \%$ & $-5.54 \%$ & $13.03 \%$ & $43.58 \%$ & $78.25 \%$ \\
\hline & \& Type of Employment & $21.38 \%$ & $13.15 \%$ & $4.03 \%$ & $8.95 \%$ & $60.59 \%$ & $88.00 \%$ \\
\hline & \& Occupation & $42.27 \%$ & $18.99 \%$ & $-14.26 \%$ & $0.52 \%$ & $47.07 \%$ & $82.04 \%$ \\
\hline & \& Economic Sector & $47.61 \%$ & $26.41 \%$ & $-12.32 \%$ & $-14.20 \%$ & $33.67 \%$ & $44.34 \%$ \\
\hline & All Variables & $18.84 \%$ & $57.38 \%$ & $-30.27 \%$ & $1.57 \%$ & $10.62 \%$ & $21.11 \%$ \\
\hline \multicolumn{8}{|c|}{ EAP } \\
\hline & & \multicolumn{6}{|c|}{ Delta $=9.62 \%$} \\
\hline & & Delta 0 & Delta $M$ & Delta F & Delta X & CSM & CSF \\
\hline \multirow{8}{*}{ 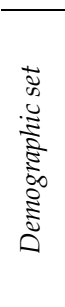 } & Country & $9.62 \%$ & $0.00 \%$ & $0.00 \%$ & $0.00 \%$ & $100.00 \%$ & $100.00 \%$ \\
\hline & + Age & $10.53 \%$ & $0.00 \%$ & $0.00 \%$ & $-0.91 \%$ & $100.00 \%$ & $100.00 \%$ \\
\hline & + Urban & $11.34 \%$ & $0.00 \%$ & $0.00 \%$ & $-1.73 \%$ & $100.00 \%$ & $100.00 \%$ \\
\hline & + Education & $15.04 \%$ & $0.05 \%$ & $0.00 \%$ & $-5.48 \%$ & $99.50 \%$ & $100.00 \%$ \\
\hline & + Marital Status & $11.63 \%$ & $-0.89 \%$ & $0.94 \%$ & $-2.06 \%$ & $96.44 \%$ & $93.81 \%$ \\
\hline & + Presence of child in the household & $11.69 \%$ & $-1.84 \%$ & $1.45 \%$ & $-1.69 \%$ & $93.94 \%$ & $90.72 \%$ \\
\hline & + Presence of older in the household & $11.90 \%$ & $-1.99 \%$ & $1.64 \%$ & $-1.93 \%$ & $93.36 \%$ & $90.06 \%$ \\
\hline & + Presence of other member with income in the household & $13.40 \%$ & $-2.95 \%$ & $0.90 \%$ & $-1.73 \%$ & $89.15 \%$ & $86.34 \%$ \\
\hline \multirow{6}{*}{ 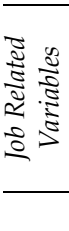 } & \& Hours of work per week & $16.43 \%$ & $-4.04 \%$ & $-0.37 \%$ & $-2.41 \%$ & $81.70 \%$ & $80.82 \%$ \\
\hline & \& Type of Employment & $13.97 \%$ & $-2.61 \%$ & $0.41 \%$ & $-2.16 \%$ & $87.85 \%$ & $85.26 \%$ \\
\hline & \& Occupation & $11.92 \%$ & $-7.33 \%$ & $3.96 \%$ & $1.07 \%$ & $68.73 \%$ & $70.52 \%$ \\
\hline & \& Economic Sector & $11.95 \%$ & $-4.44 \%$ & $1.22 \%$ & $0.88 \%$ & $65.47 \%$ & $70.03 \%$ \\
\hline & \& Formality & $13.84 \%$ & $-3.60 \%$ & $1.81 \%$ & $-2.43 \%$ & $84.80 \%$ & $82.46 \%$ \\
\hline & All Variables & $14.49 \%$ & $-16.35 \%$ & $7.97 \%$ & $3.51 \%$ & $30.97 \%$ & $39.78 \%$ \\
\hline
\end{tabular}

\section{WESTER EUROPE}

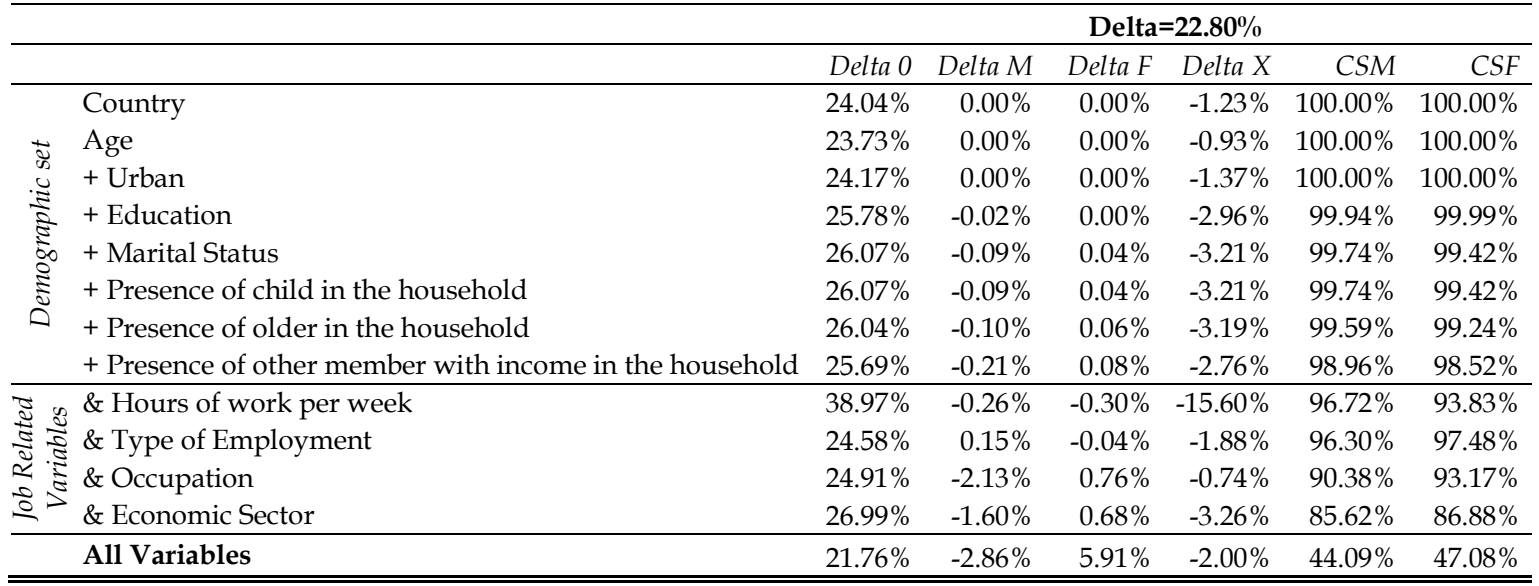

Source: Authors' calculations using Household Surveys (World Bank) 
Table 5. Original and Unexplained Components of the Gender Wage Gap, by Country

\begin{tabular}{|c|c|c|c|}
\hline \multirow[b]{2}{*}{ Country } & \multirow[b]{2}{*}{ Delta } & \multicolumn{2}{|c|}{ Delta 0} \\
\hline & & $\begin{array}{l}\text { Demographic } \\
\text { Variables }\end{array}$ & All Variables \\
\hline CONGO & $52.50 \%$ & $33 \% *$ & $20.47 \%$ \\
\hline COMOROS & $50.20 \%$ & $40.46 \%$ * & $85.26 \%$ * \\
\hline GHANA & $44.20 \%$ & $27.22 \% *$ & $57.34 \%$ * \\
\hline MADAGASCAR & $42.63 \%$ & $23.73 \% *$ & $-1.91 \%$ \\
\hline TANZANIA & $38.02 \%$ & $45.11 \%$ & $41.41 \%$ * \\
\hline NIGERIA & $-14.17 \%$ & $-8.20 \%$ & $3.76 \%$ \\
\hline SSA & $34.50 \%$ & $28.85 \% \%^{*}$ & $31.02 \%$ * \\
\hline YEMEN & $23.36 \%$ & $10.13 \%$ & $11.81 \%$ \\
\hline TUNISIA & $4.04 \%$ & $5.65 \% *$ & $12.16 \%$ * \\
\hline MENA & $8.25 \%$ & $6.09 \% *$ & $12.24 \%$ * \\
\hline ESTONIA & $39.01 \%$ & $45.14 \% *$ & $48.7 \%$ * \\
\hline CZECH REPUBLIC & $33.18 \%$ & $32.78 \% *$ & $35.19 \%$ * \\
\hline ALBANIA & $30.07 \%$ & $35.15 \% *$ & $48.75 \%$ * \\
\hline SLOVAKIA & $26.74 \%$ & $32.4 \% *$ & $30.06 \%$ * \\
\hline TAJIKISTAN & $25.17 \%$ & $37 \% *$ & $19.63 \%$ \\
\hline LATVIA & $25.01 \%$ & $38.89 \% *$ & $42.47 \%$ * \\
\hline BULGARIA & $21.97 \%$ & $30.11 \% *$ & $31.33 \%$ * \\
\hline CROATIA & $13.97 \%$ & $22.11 \% *$ & $19.78 \%$ * \\
\hline HUNGARY & $13.76 \%$ & $24.8 \% *$ & $26.05 \%$ * \\
\hline POLAND & $10.25 \%$ & $20.66 \%$ * & $26.79 \%$ * \\
\hline MOLDOVA & $8.88 \%$ & $2.73 \%$ & $-4.84 \%$ \\
\hline BOSNIA AND HERZEGOVINA & $5.73 \%$ & $9.81 \%$ & $3.15 \%$ \\
\hline ECA & $17.80 \%$ & $25.74 \%{ }^{*}$ & $27.49 \%$ * \\
\hline NEPAL & $47.51 \%$ & $21.38 \%$ & $18.84 \%$ \\
\hline SA & $47.51 \%$ & $21.38 \%$ & $18.84 \%$ \\
\hline MONGOLIA & $9.62 \%$ & $13.4 \% *$ & $14.49 \%$ * \\
\hline EAP & $9.62 \%$ & $13.4 \%$ * & $14.49 \%$ * \\
\hline UNITED KINGDOM & $38.02 \%$ & $37.55 \% *$ & $24.62 \% *$ \\
\hline CYPRUS & $33.47 \%$ & $31.61 \% *$ & $23.43 \%$ * \\
\hline LUXEMBOURG & $31.33 \%$ & $28.01 \% *$ & $20.16 \%$ * \\
\hline GERMANY & $29.55 \%$ & $26.64 \% *$ & $20.9 \%$ * \\
\hline ICELAND & $25.00 \%$ & $30.05 \% *$ & $42.27 \%$ * \\
\hline FINLAND & $22.10 \%$ & $26.49 \% *$ & $26.35 \%$ * \\
\hline PORTUGAL & $20.71 \%$ & $36.34 \% *$ & $40.75 \%$ * \\
\hline SPAIN & $14.21 \%$ & $19.02 \% *$ & $20.83 \%$ * \\
\hline ITALY & $13.04 \%$ & $19.87 \% *$ & $24.16 \%$ * \\
\hline BELGIUM & $12.84 \%$ & $13.14 \% *$ & $11.8 \%$ * \\
\hline GREECE & $12.43 \%$ & $16.76 \%$ * & $17.61 \%$ * \\
\hline IRELAND & $11.02 \%$ & $8.11 \% *$ & $7.42 \%$ \\
\hline AUSTRIA & $10.40 \%$ & $11.54 \% *$ & $13.47 \%$ * \\
\hline WESTERN EUROPE & $22.80 \%$ & $25.69 \%$ * & $21.76 \%$ * \\
\hline
\end{tabular}

Source: Authors' calculations using Household Surveys (World Bank)

* Statistically different than zero at the $99 \%$ level 


\section{Beyond averages. Exploring the distribution of unexplained gender earnings differences}

One of the advantages of the matching approach is that it allows an exploration of unexplained gender differences in pay within different segments of the labor markets. In this way we can report that (these results are shown on Figures 1 to 12):

- For SSA the highest unexplained gender differences in pay are found among those who live with another labor income generator within their households, those working in "communal services" and those holding informal jobs.

- For MENA the highest unexplained gaps are found among younger workers (15-24) with none or primary education, with no presence of elderly at their households, working either part-time or over-time (but not full-time) and among those with lower earnings.

- In ECA the situation slightly differs as the highest unexplained gaps are found among married part-time workers, living with elderly and with no other labor income generator at home. Is SA, as in MENA, the highest earnings gaps are among those with none or primary incomplete education; and as in ECA, for those with no other income generator at home. Additionally, the unexplained earnings gaps in SA are high among those working in elementary occupations.

- EAP is the only region of the world for which there is no clear segment of the market in which the earnings gaps are more pronounced. The unexplained earnings gaps are almost equally pronounced across all segments.

- The situation in Western Europe shows some similarities, but also some differences with respect to what happens in other regions of the world. On one hand, two elements in Western Europe that contrast with the rest of the world are that the unexplained gender earnings gaps are more pronounced among older worker ( 35 years old and older) and in urban areas. On the other hand, as in MENA and SA, those with no education or primary incomplete are those who suffer from the highest unexplained earnings disparities. Along the same line of similarities with respect to other regions of the world, part-time workers suffer from higher unexplained gaps, as in MENA and ECA. And similarly to ECA as well, married workers suffer from high unexplained gaps; but the gaps are also high among divorced people in Western Europe. 
Figure 1. Confidence Intervals for the Unexplained Gender Earnings Gap (after Controlling for Demographic and Job-Related Characteristics) by Different Characteristics - SSA Region
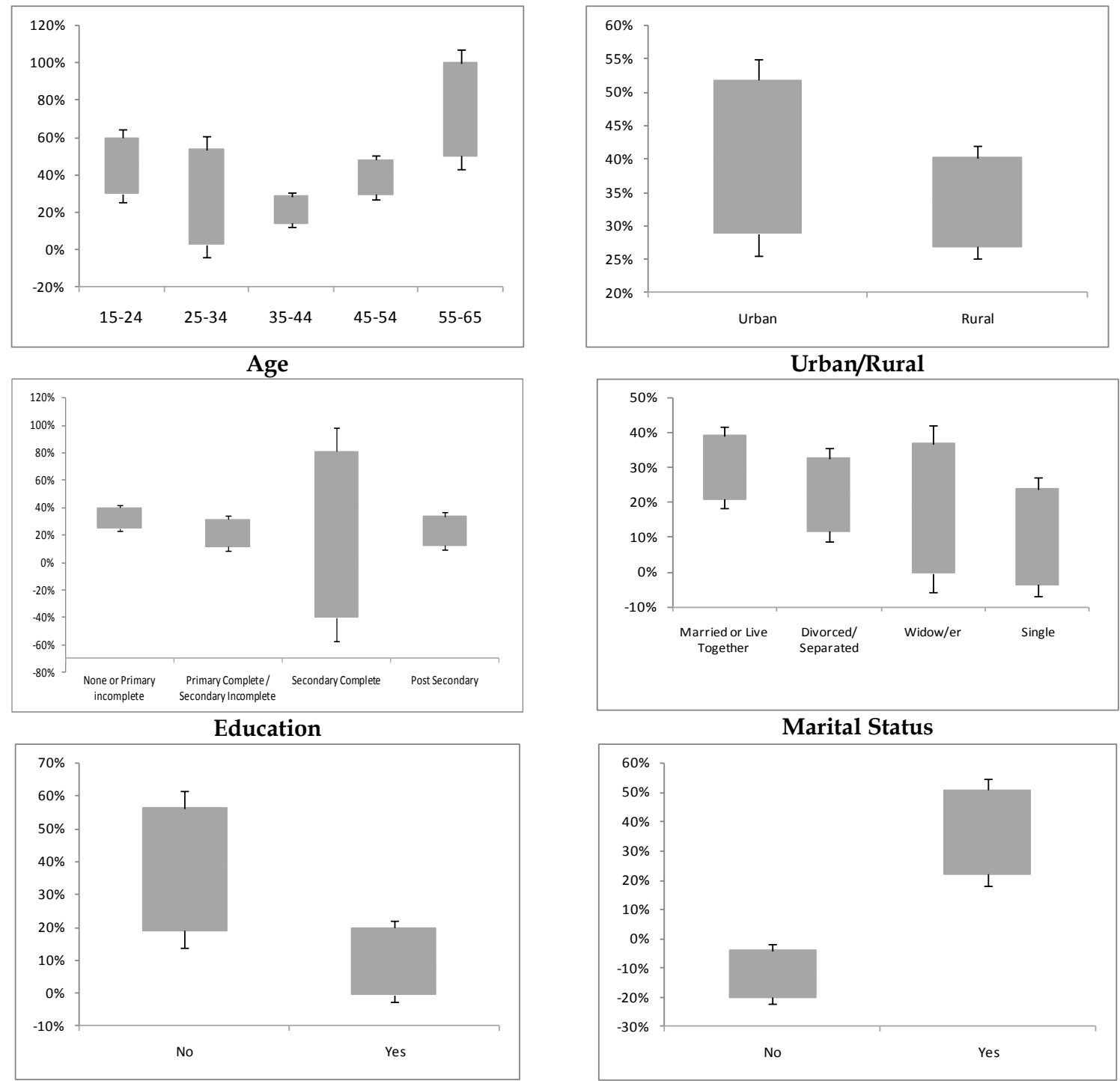

Presence of Children in the Household

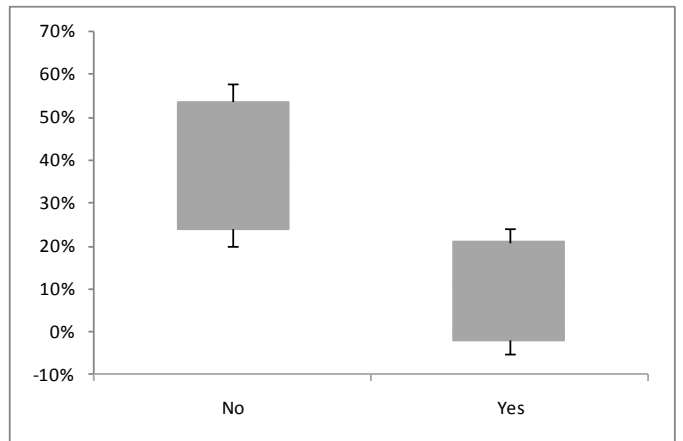

Presence of other Household Member with Labor Income

Presence of Elderly in the Household

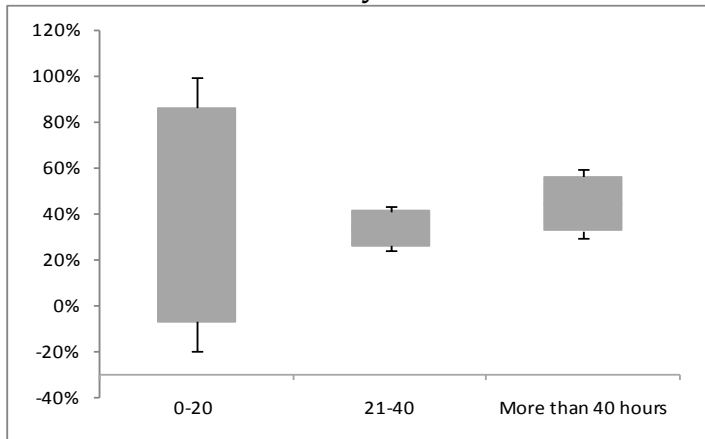

Hours of work per week 


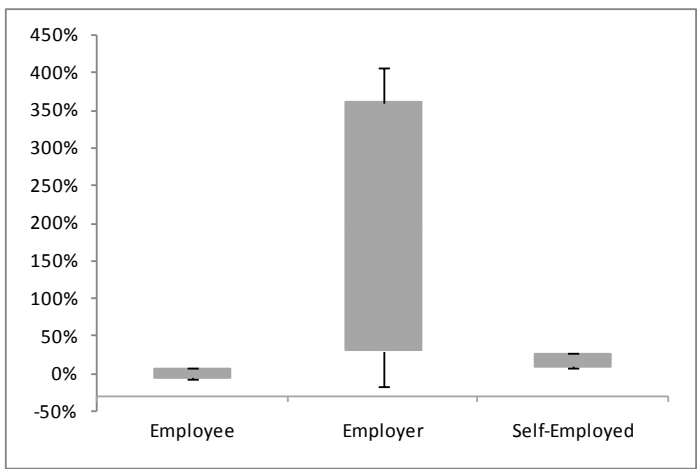

Type of Employment

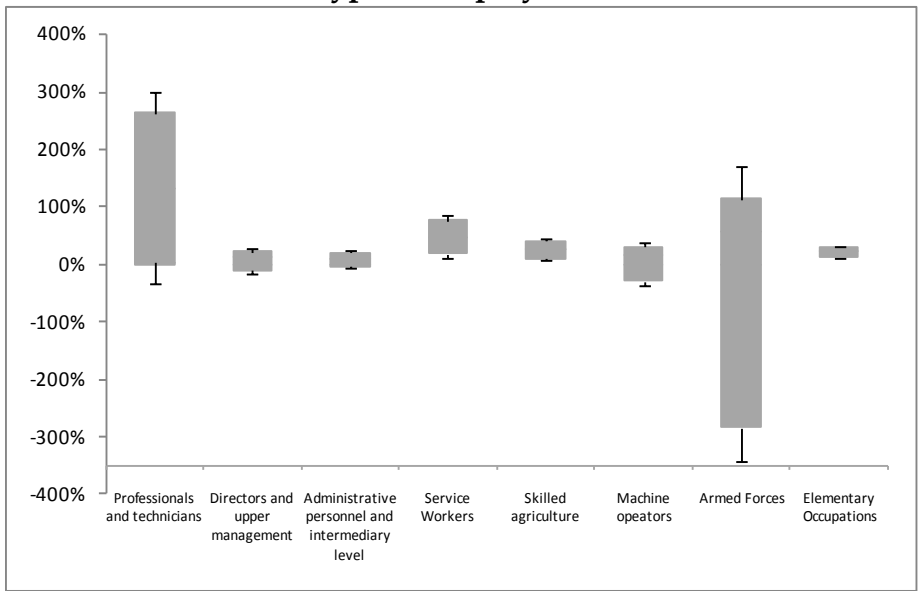

Occupation

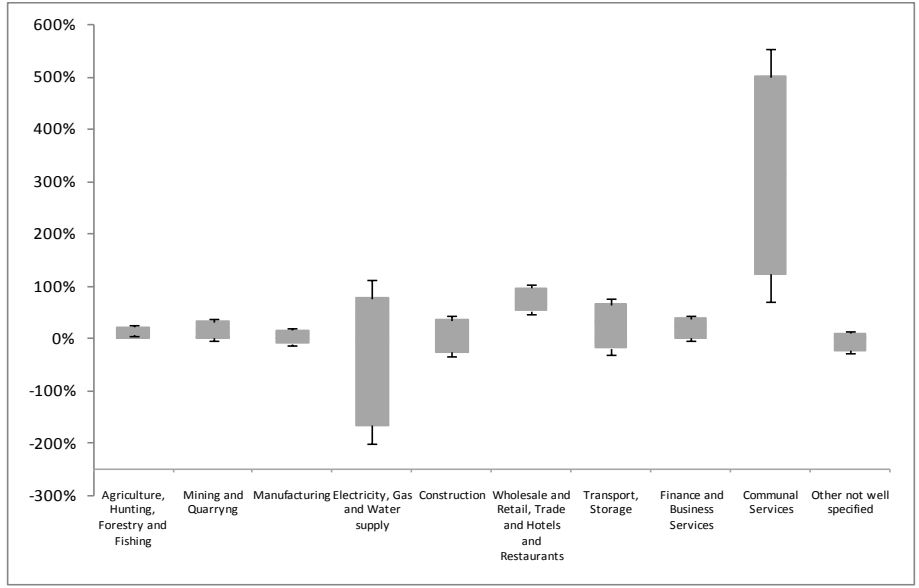

Economic sector

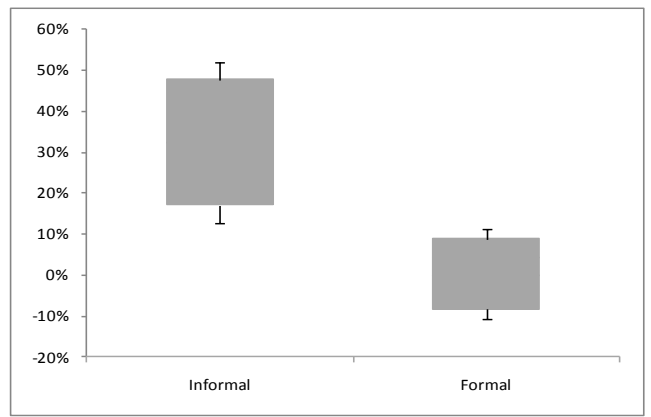

Formality

Source: Authors' calculations using Household Surveys (World Bank) 
Figure 2. Confidence Intervals for the Unexplained Gender Earnings Gap (after Controlling for Demographic and Job-Related Characteristics) by Different Characteristics - MENA Region
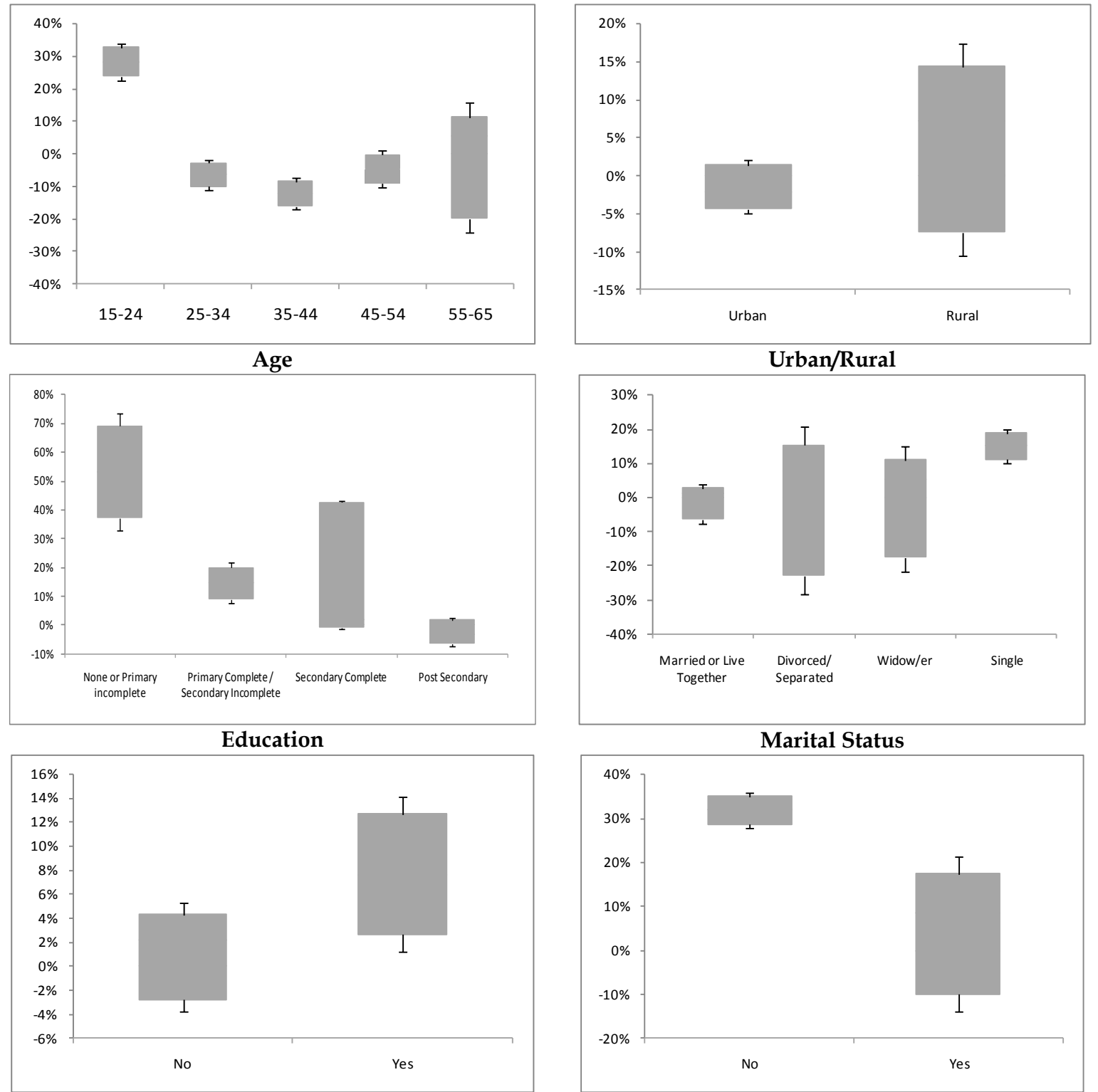

Presence of Children in the Household

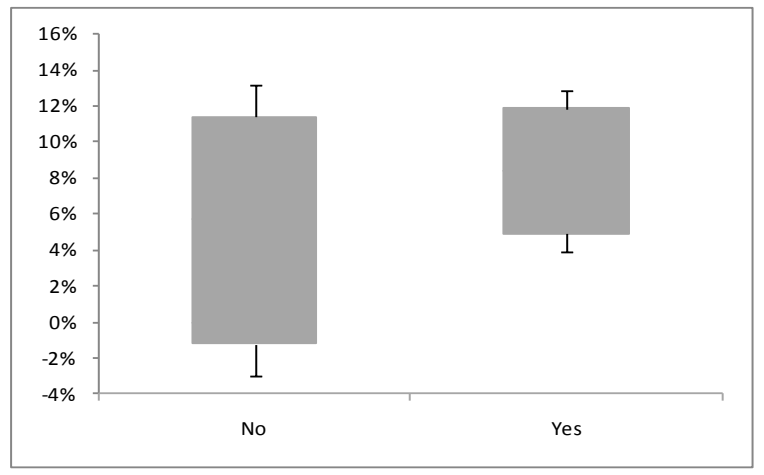

Presence of other Household Member with Labor Income

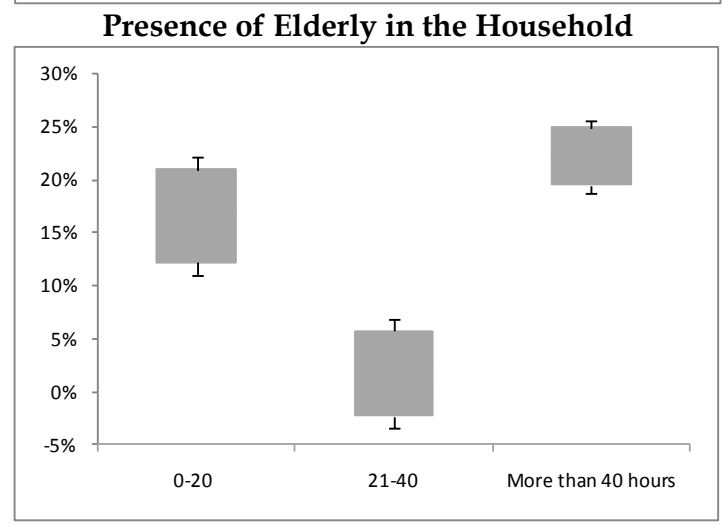

Hours of work per week 


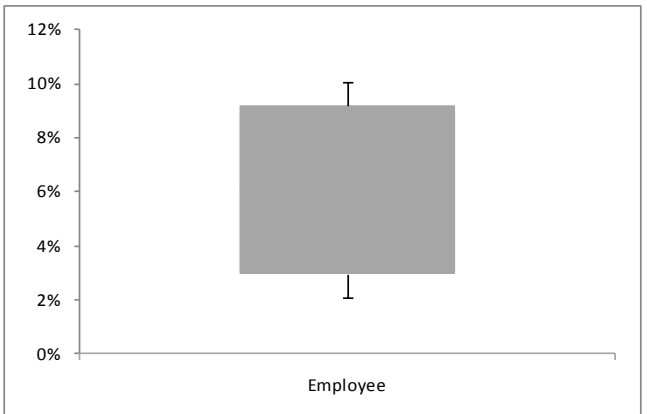

Type of Employment

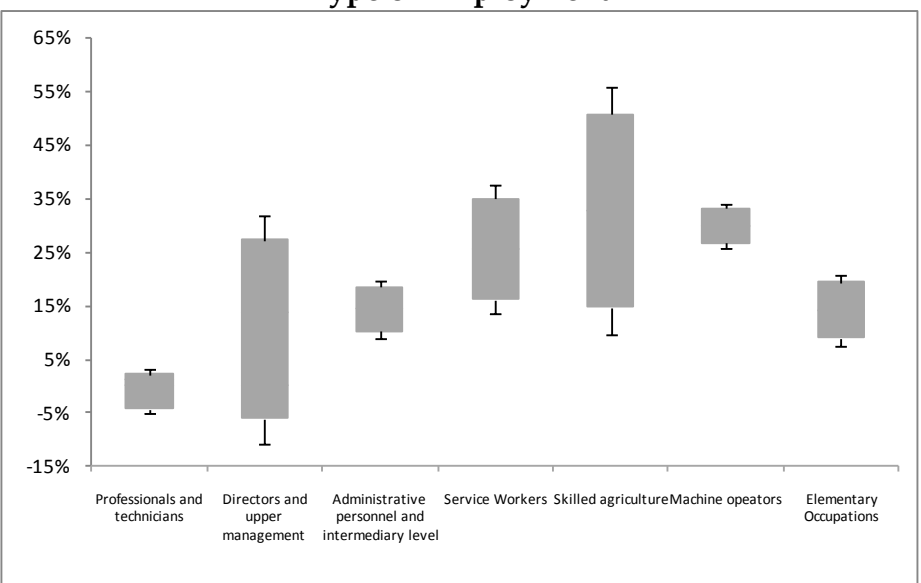

Occupation

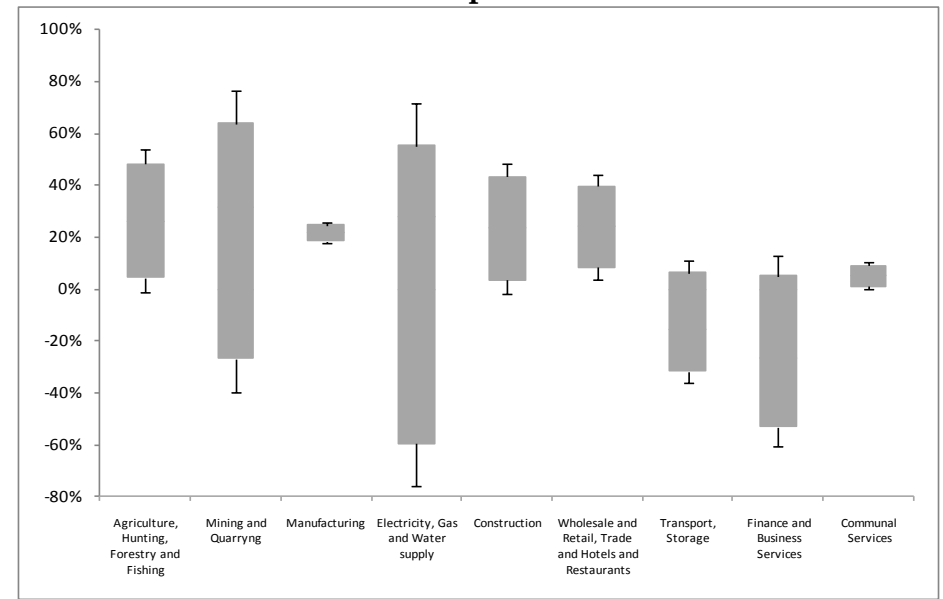

Economic sector

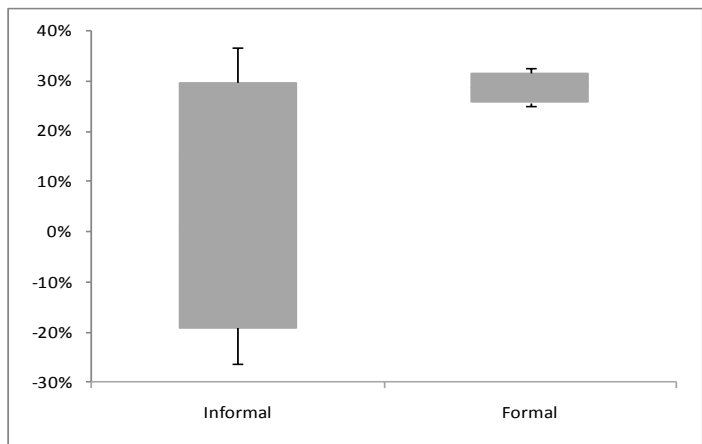

Formality

Source: Authors' calculations using Household Surveys (World Bank) 
Figure 3. Confidence Intervals for the Unexplained Gender Earnings Gap (after Controlling for Demographic and Job-Related Characteristics) by Different Characteristics - ECA Region
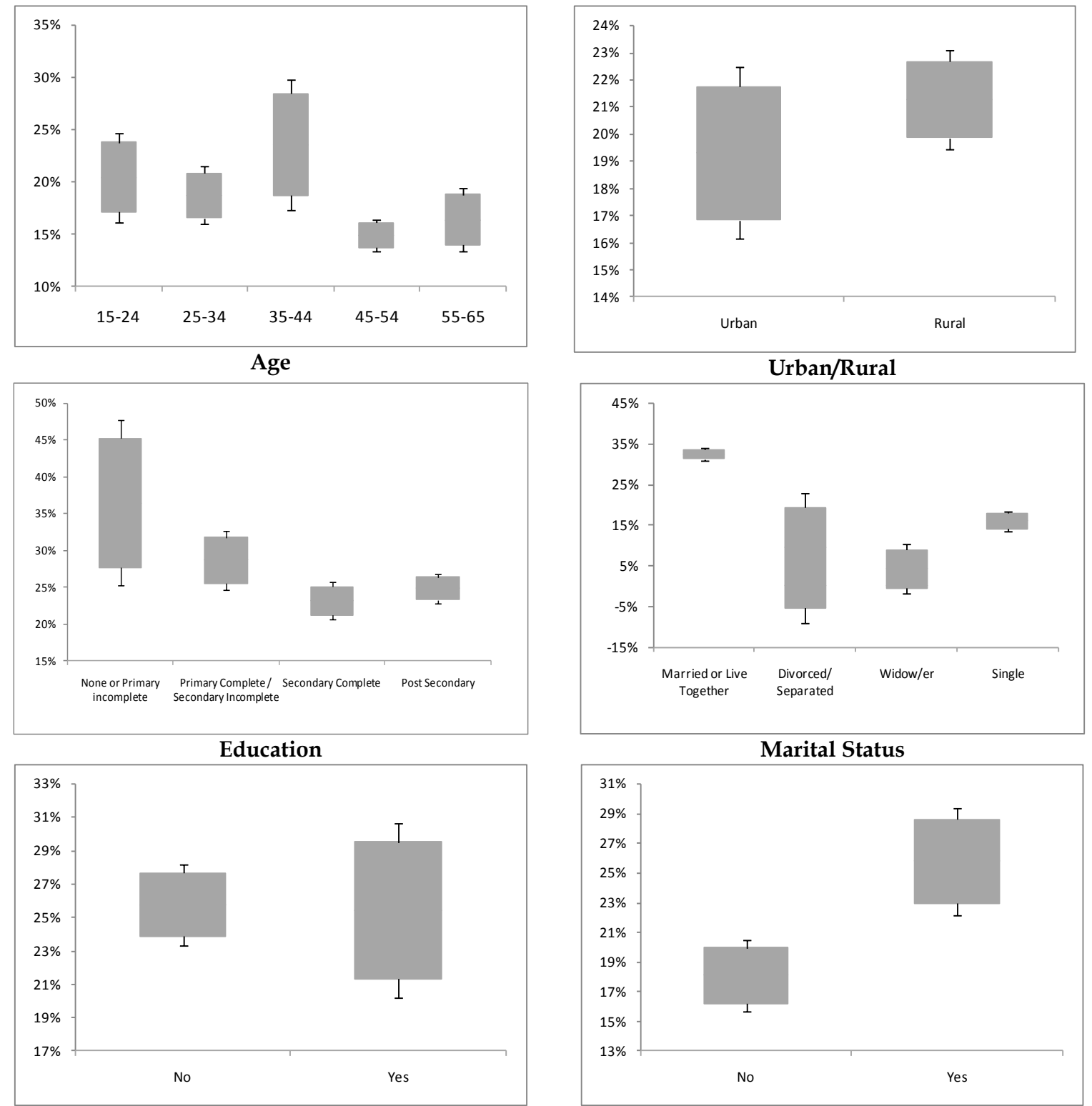

Presence of Children in the Household

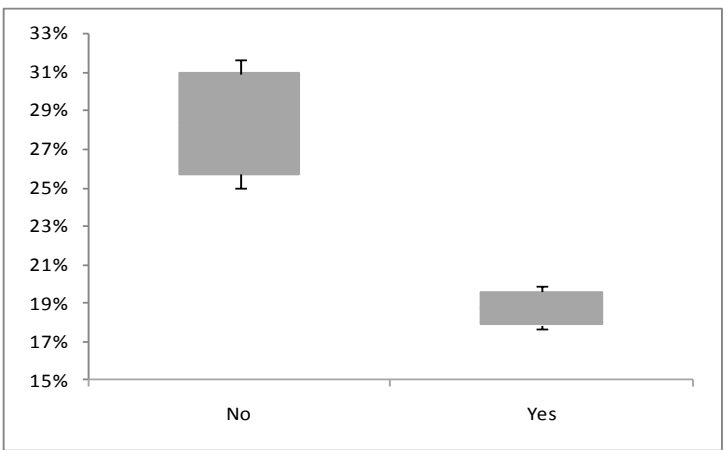

Presence of other Household Member with Labor Income

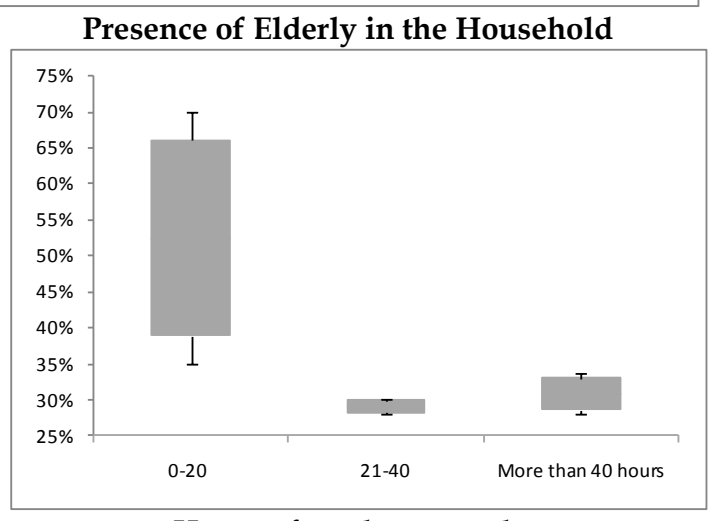

Hours of work per week 


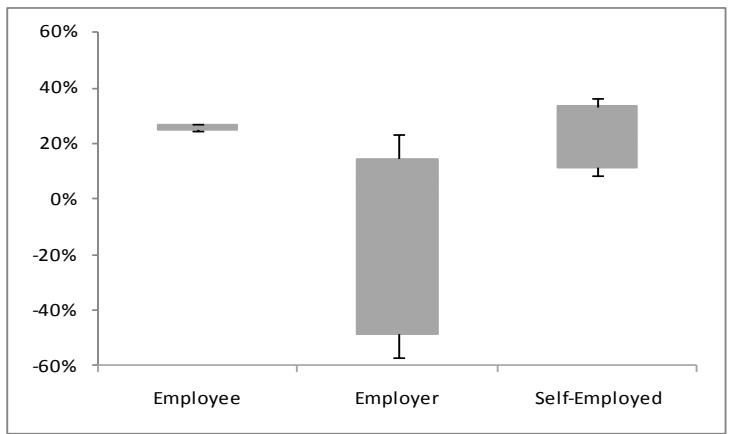

Type of Employment
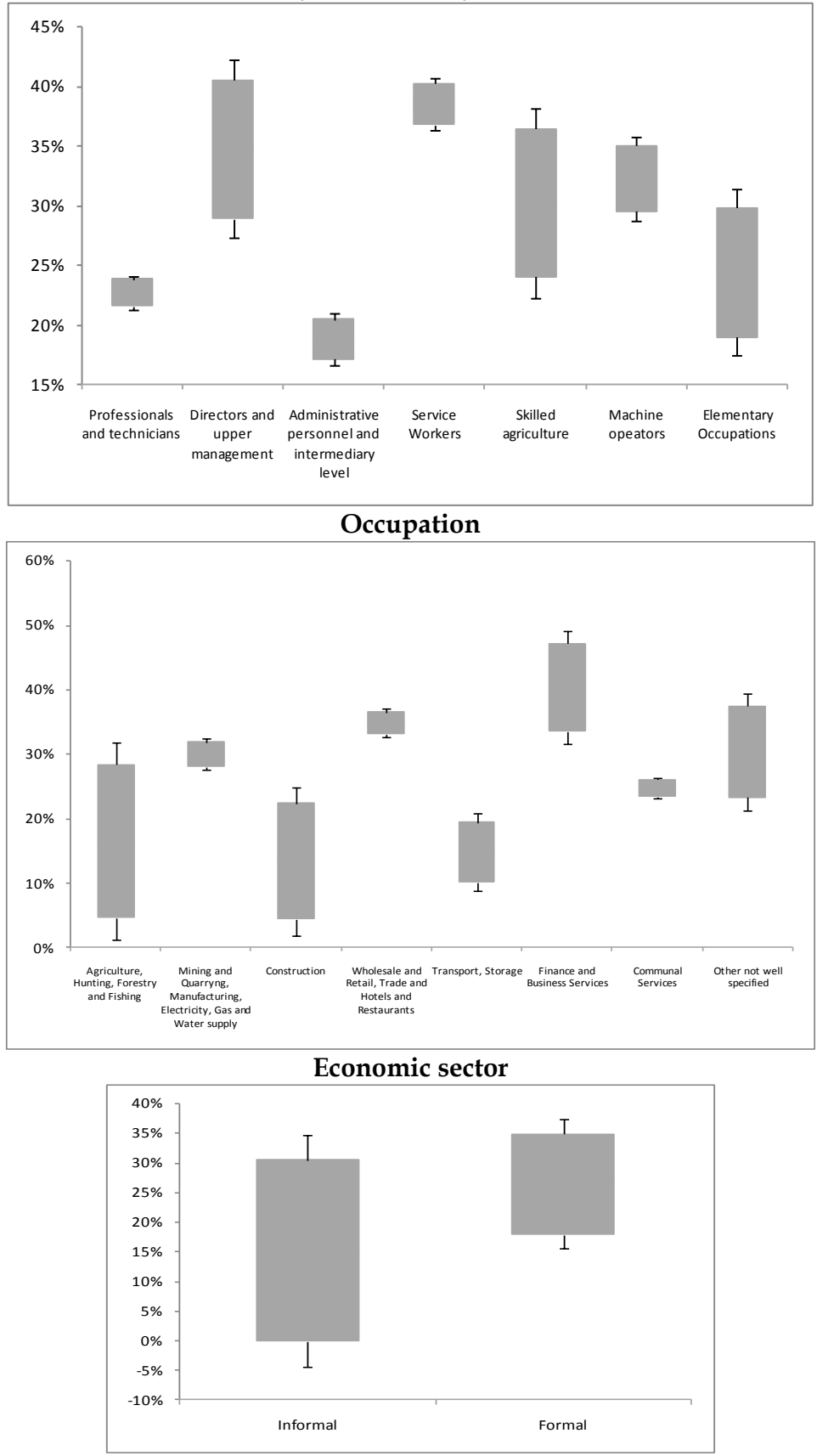

Formality

Source: Authors' calculations using Household Surveys (World Bank) 
Figure 4. Confidence Intervals for the Unexplained Gender Earnings Gap (after Controlling for Demographic and Job-Related Characteristics) by Different Characteristics - SA Region
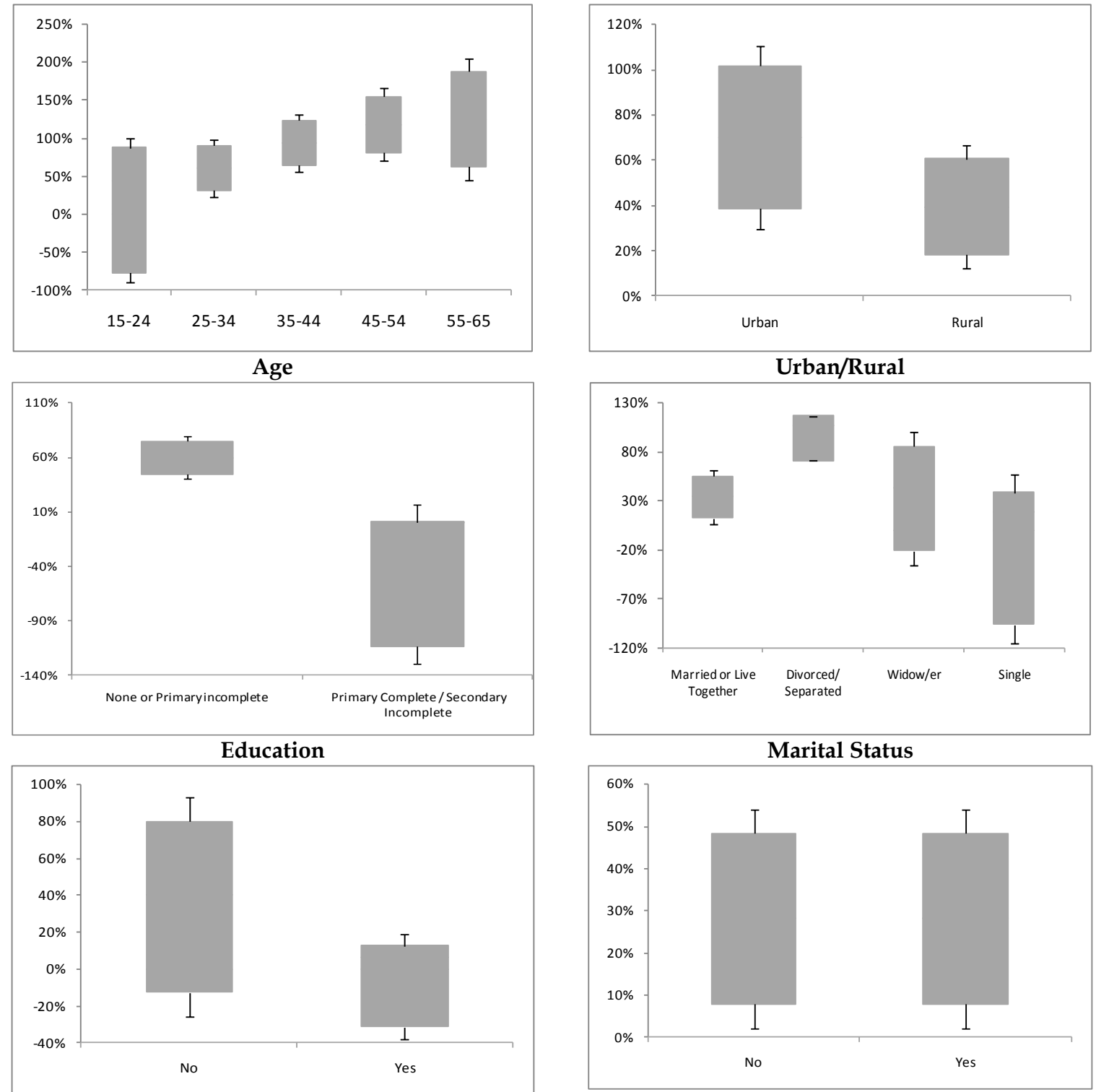

Presence of Children in the Household

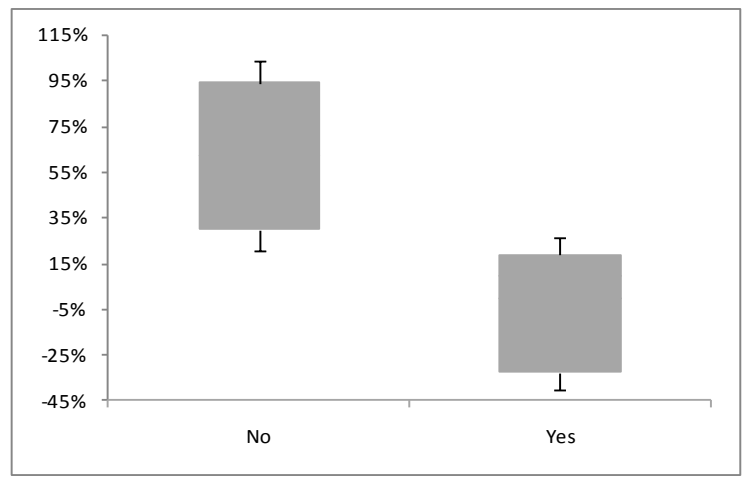

Presence of other Household Member with Labor Income

Presence of Elderly in the Household

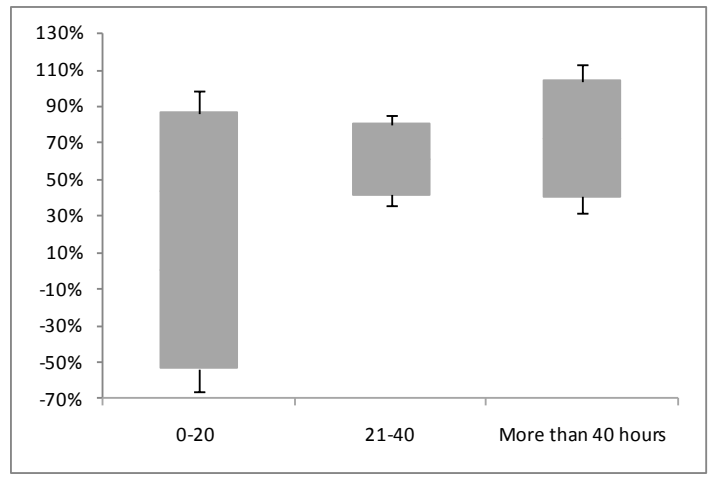

Hours of work per week 


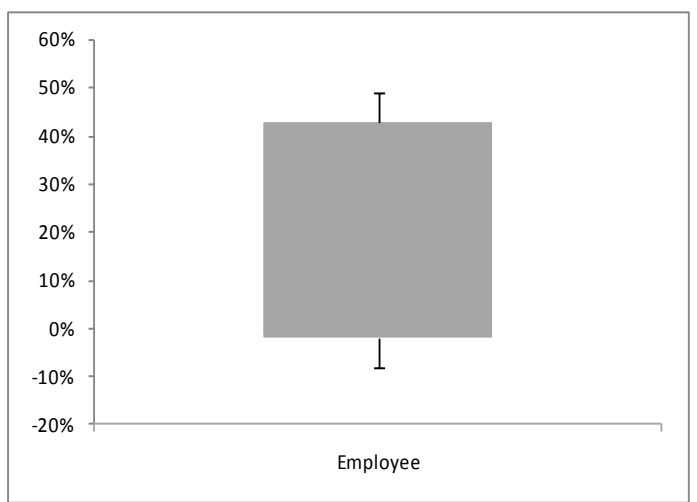

Type of Employment

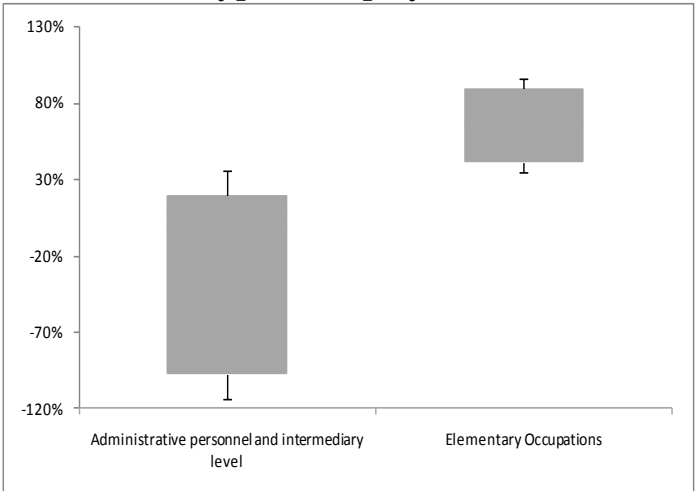

Occupation

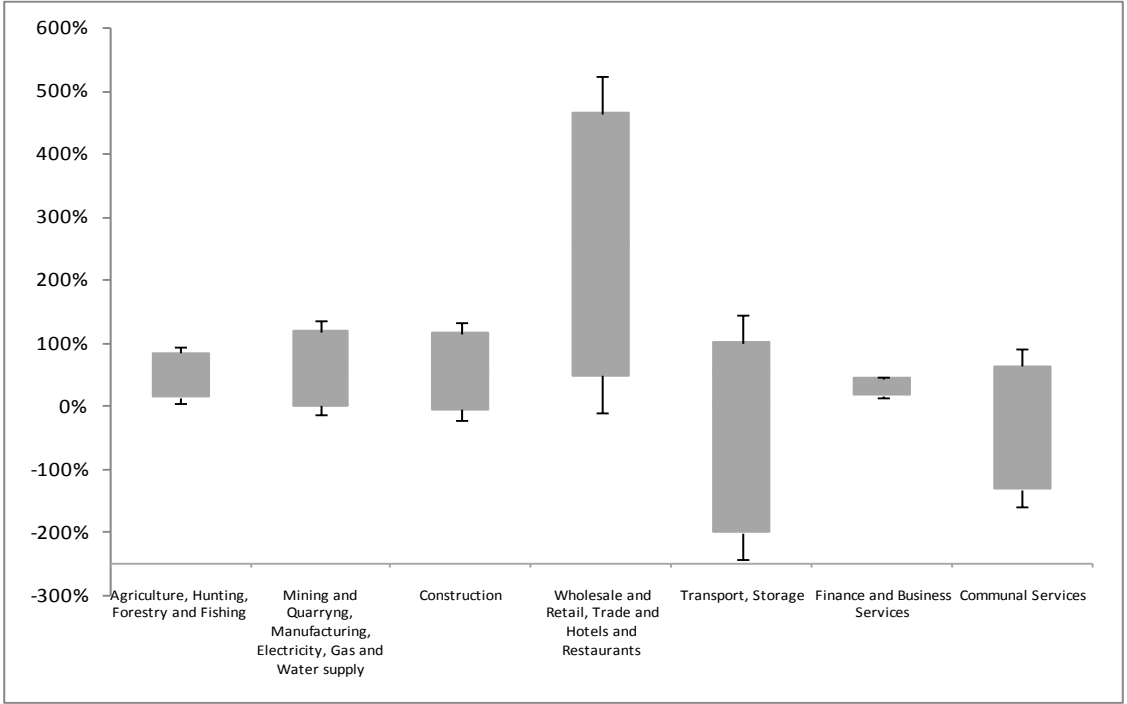

Economic Sector

Source: Authors' calculations using Household Surveys (World Bank) 
Figure 5. Confidence Intervals for the Unexplained Gender Earnings Gap (after Controlling for Demographic and Job-Related Characteristics) by Different Characteristics - EAP Region
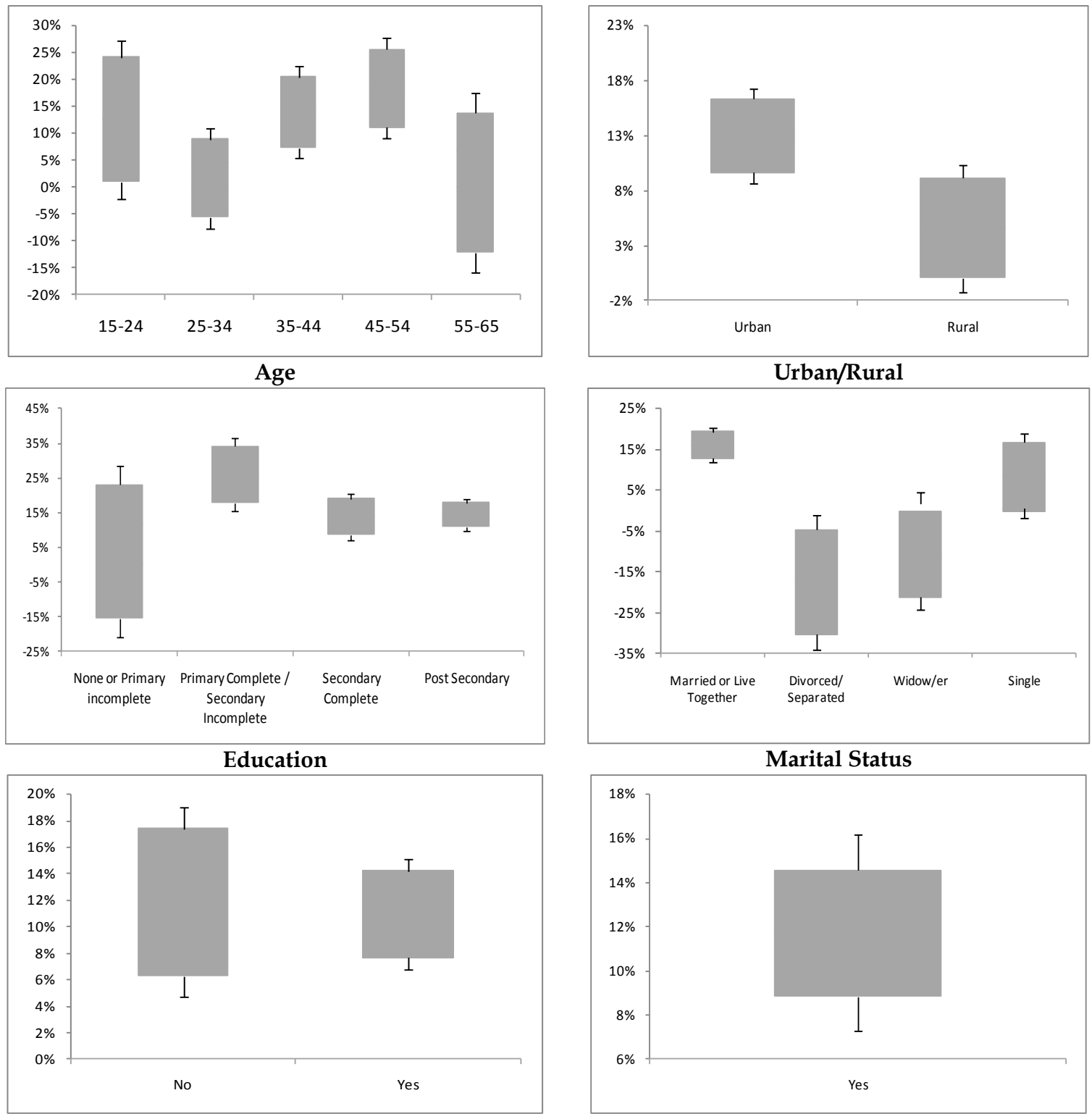

Presence of Children in the Household

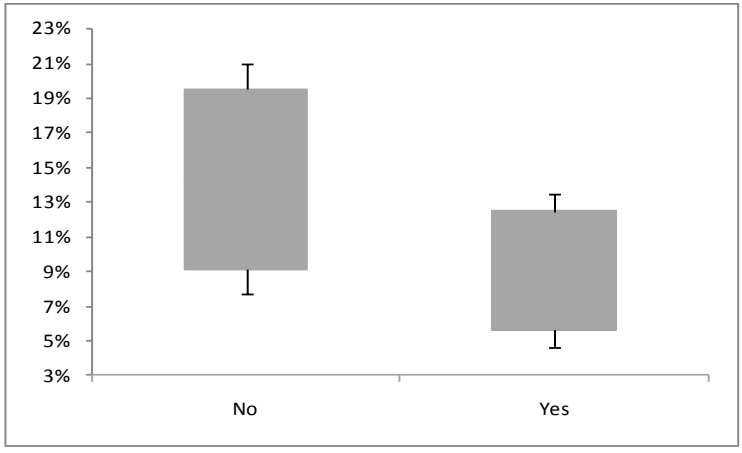

Presence of other Household Member with Labor Income

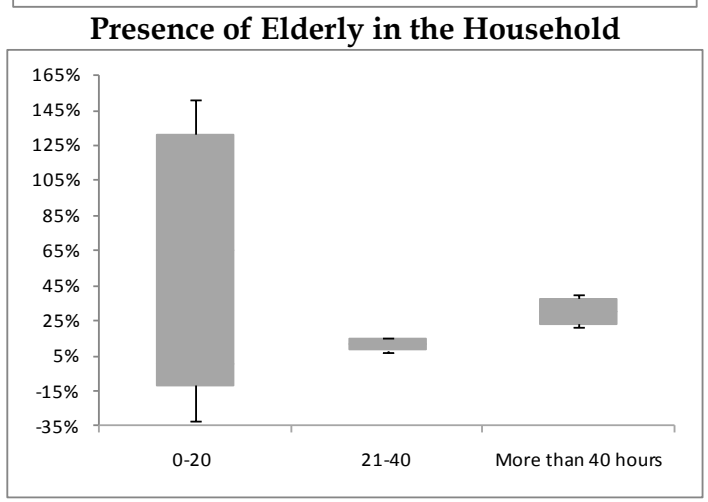

Hours of work per week 


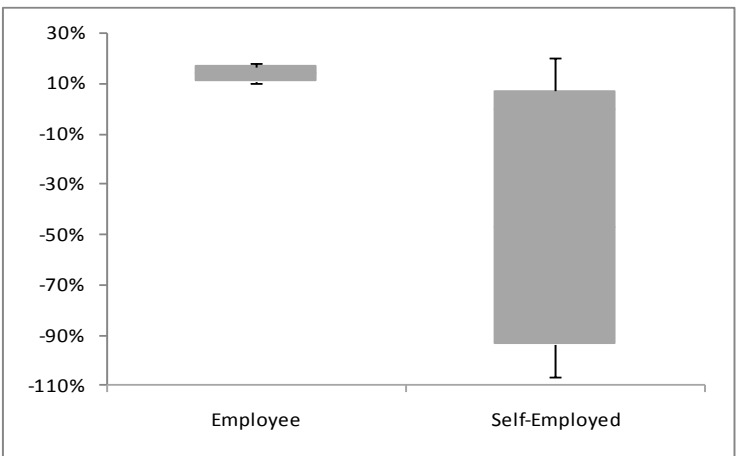

Type of Employment

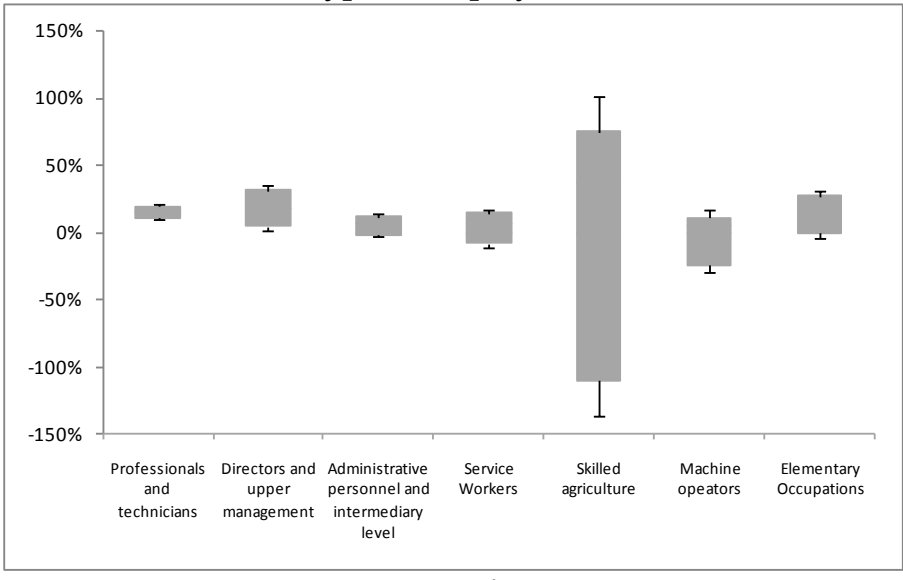

Occupation

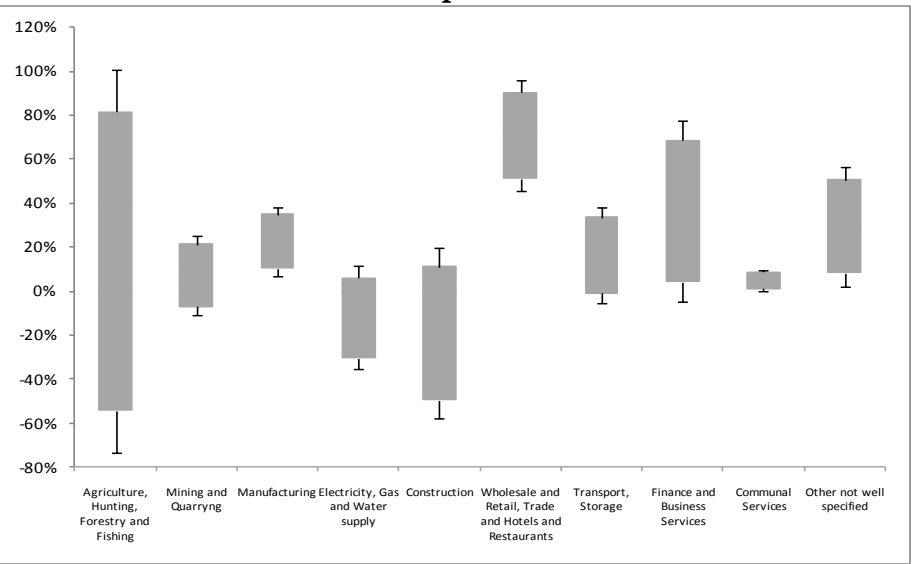

Economic sector

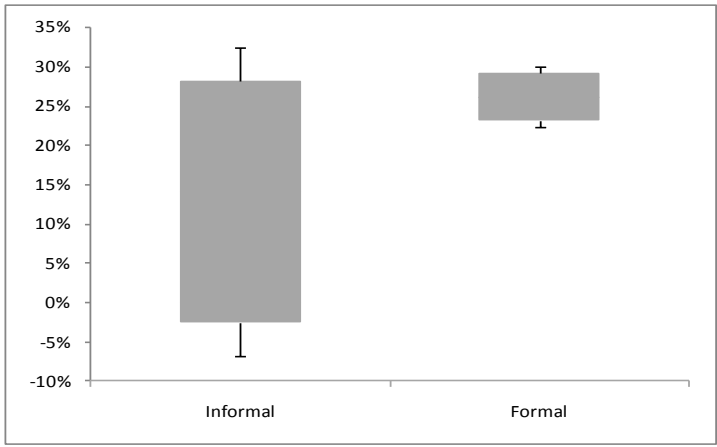

Formality

Source: Authors' calculations using Household Surveys (World Bank) 
Figure 6. Confidence Intervals for the Unexplained Gender Earnings Gap (after Controlling for Demographic and Job-Related Characteristics)

by Different Characteristics - Western Europe Region
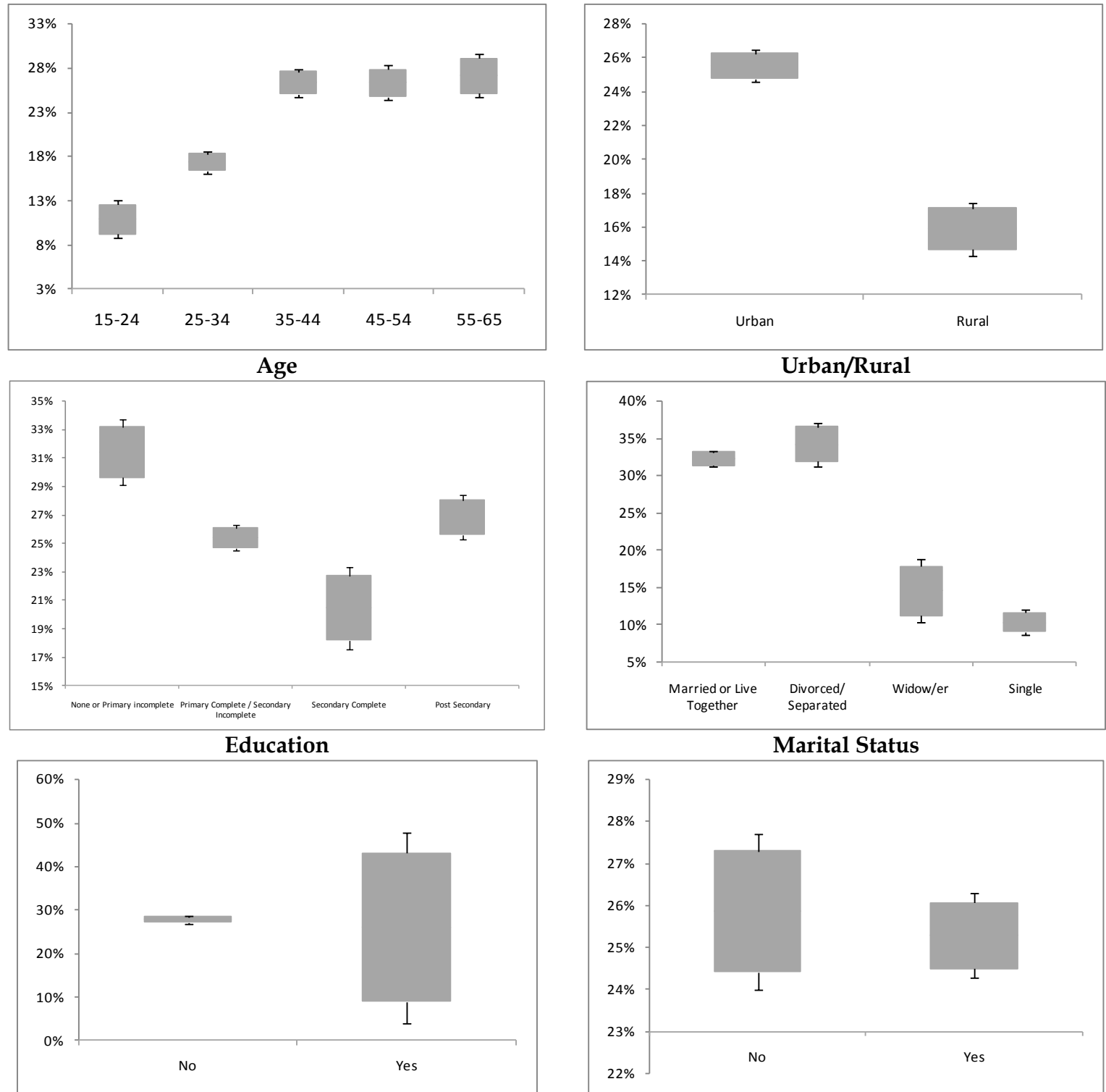

Presence of Elderly in the Household

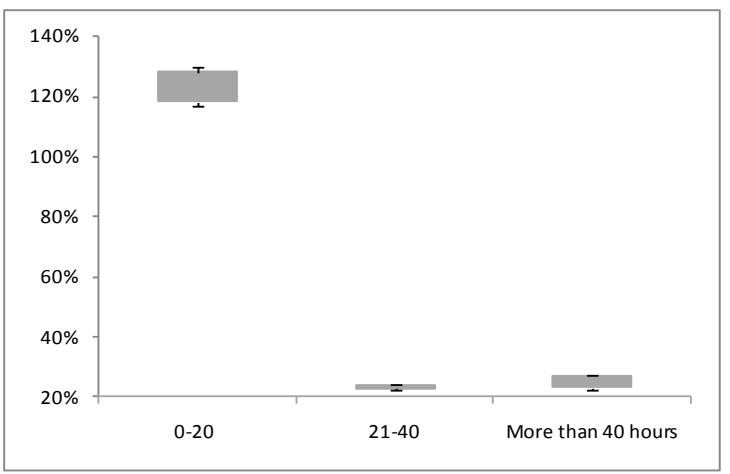

Hours of work per week

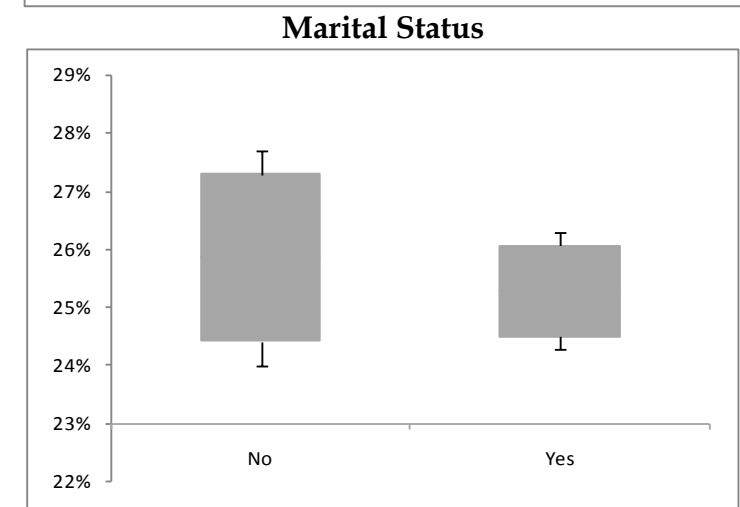

Presence of other Household Member with Labor Income

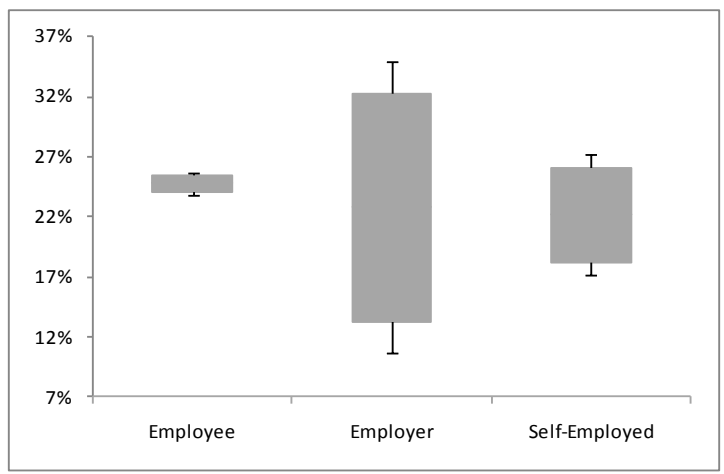

Type of Employment 


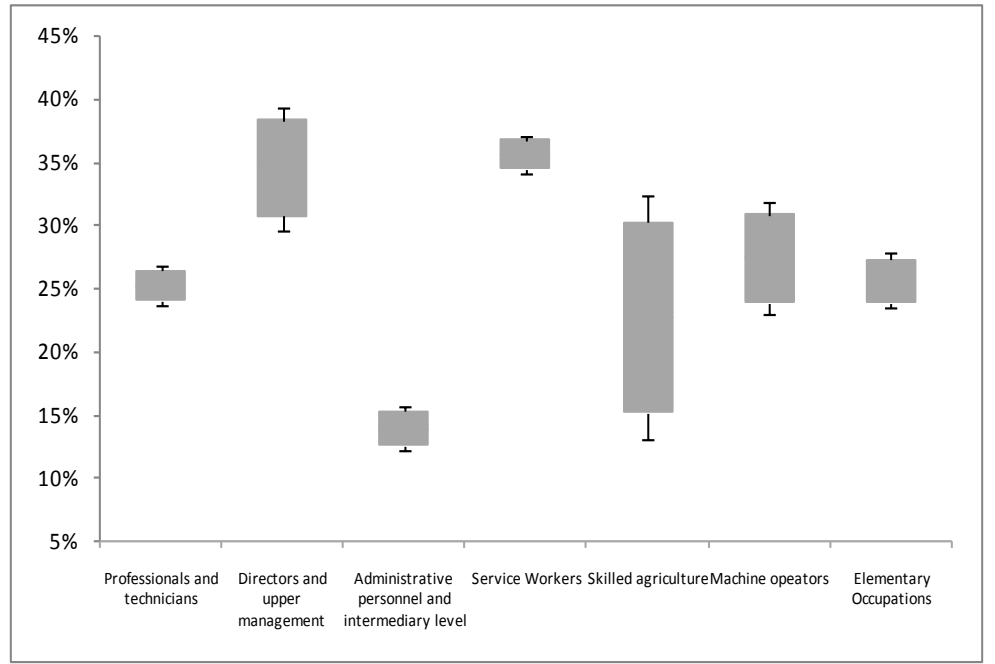

Occupation

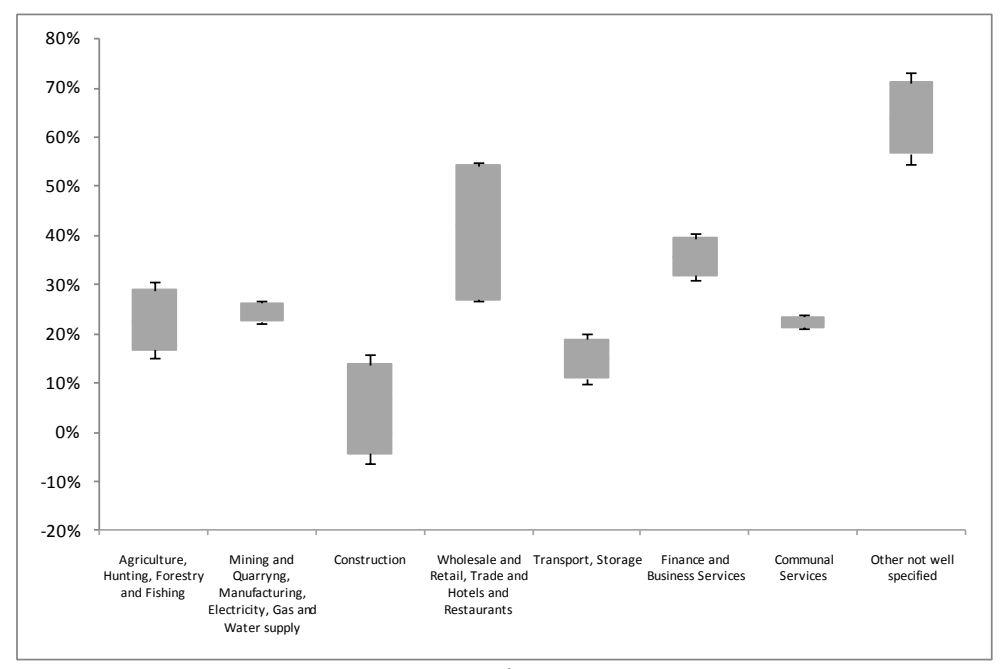

Economic sector

Source: Authors' calculations using Household Surveys (World Bank) 
Figure 7. Unexplained Gender Earnings Gap by Percentiles of the Earnings Distribution of Males and Females-SSA

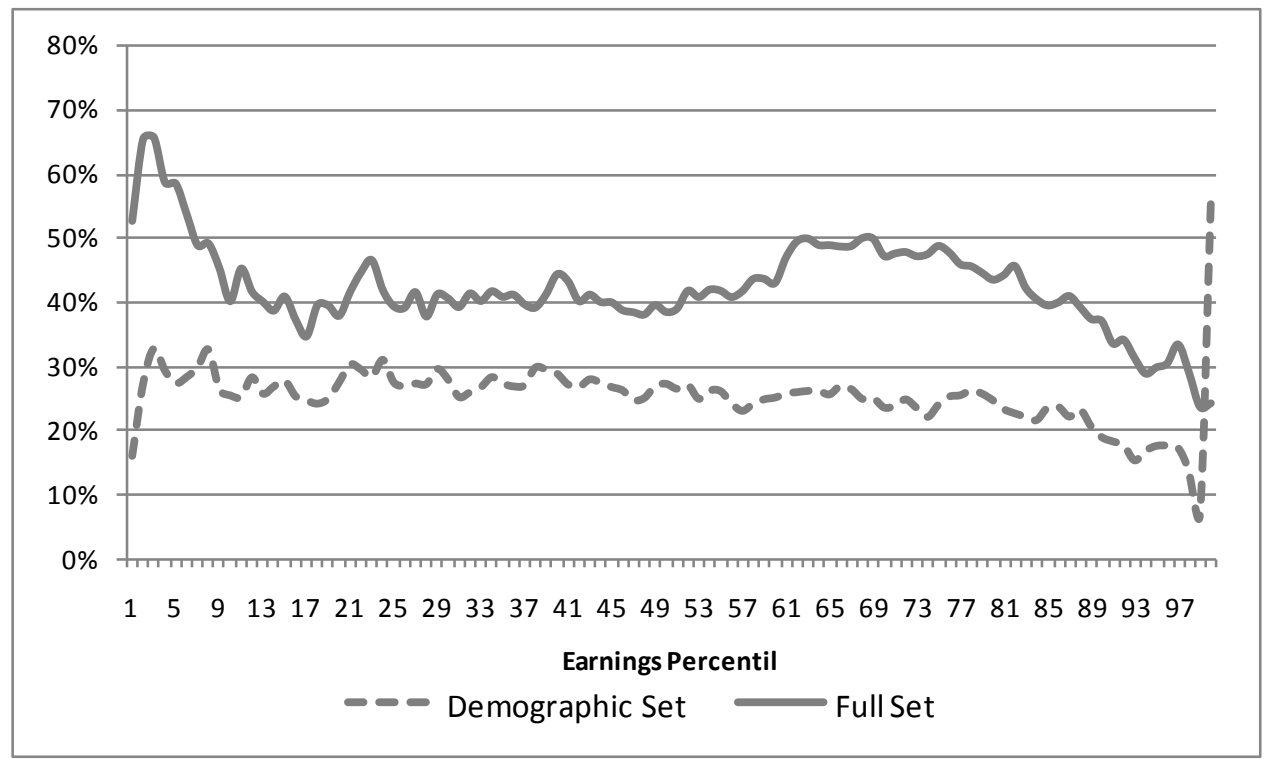

Source: Authors' calculations using Household Surveys (World Bank)

Figure 8. Unexplained Gender Earnings Gap by Percentiles of the Earnings Distribution of Males and Females-MENA

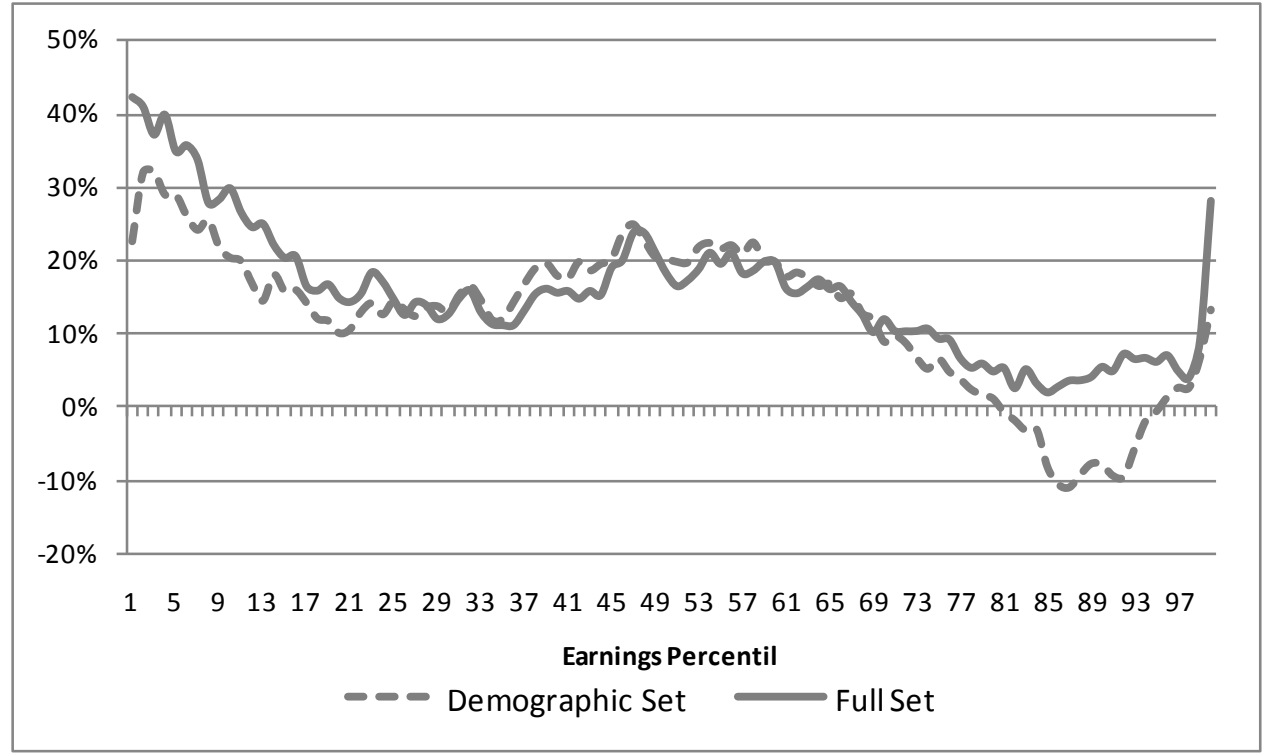

Source: Authors' calculations using Household Surveys (World Bank) 
Figure 9. Unexplained Gender Earnings Gap by Percentiles of the Earnings Distribution of Males and Females-ECA

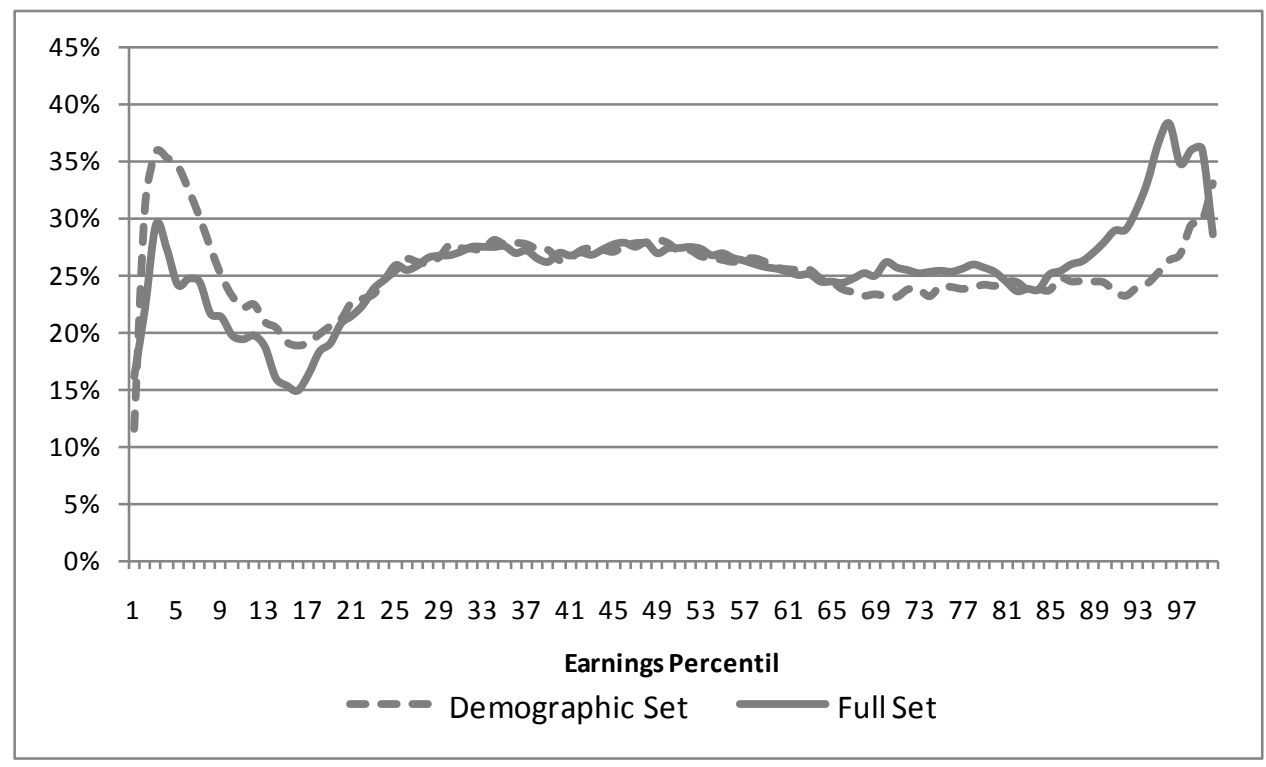

Source: Authors' calculations using Household Surveys (World Bank)

Figure 10. Unexplained Gender Earnings Gap by Deciles of the Earnings Distribution of Males and Females-SA

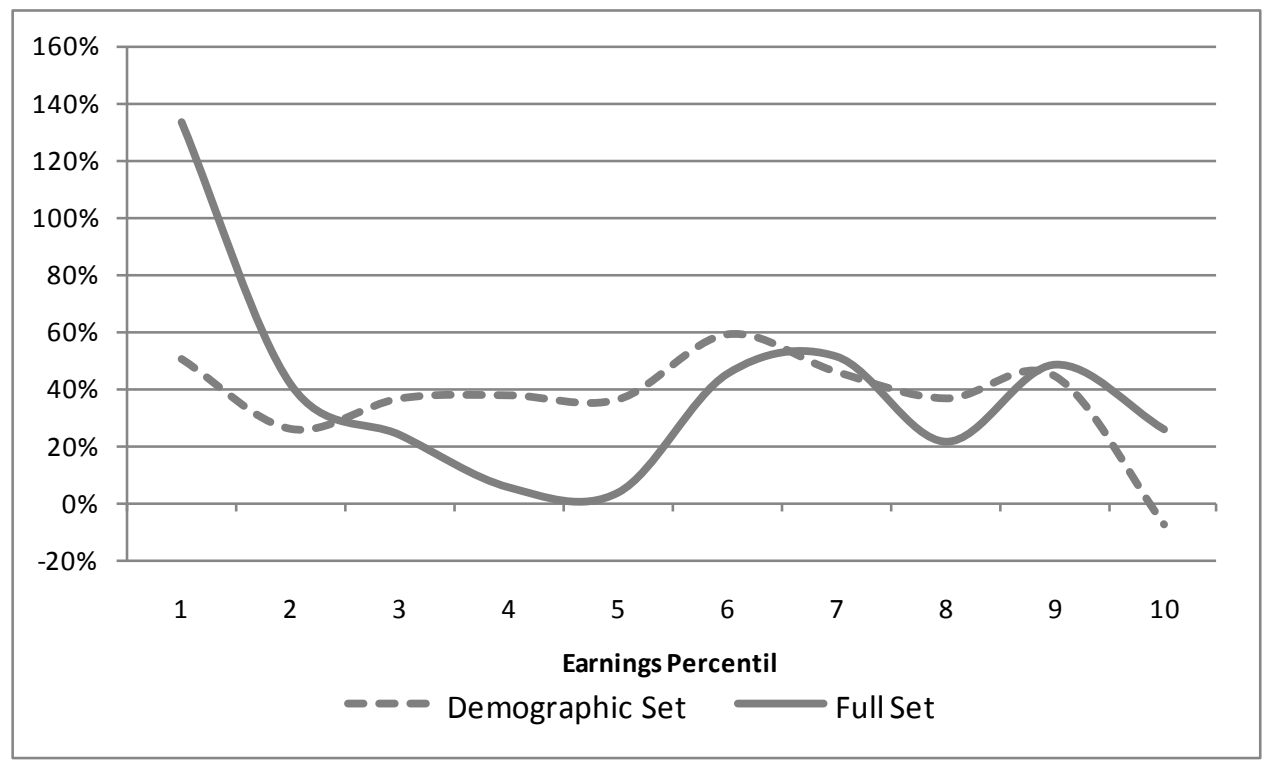

Source: Authors' calculations using Household Surveys (World Bank) 
Figure 11. Unexplained Gender Earnings Gap by Percentiles of the Earnings Distribution of Males and Females-EAP

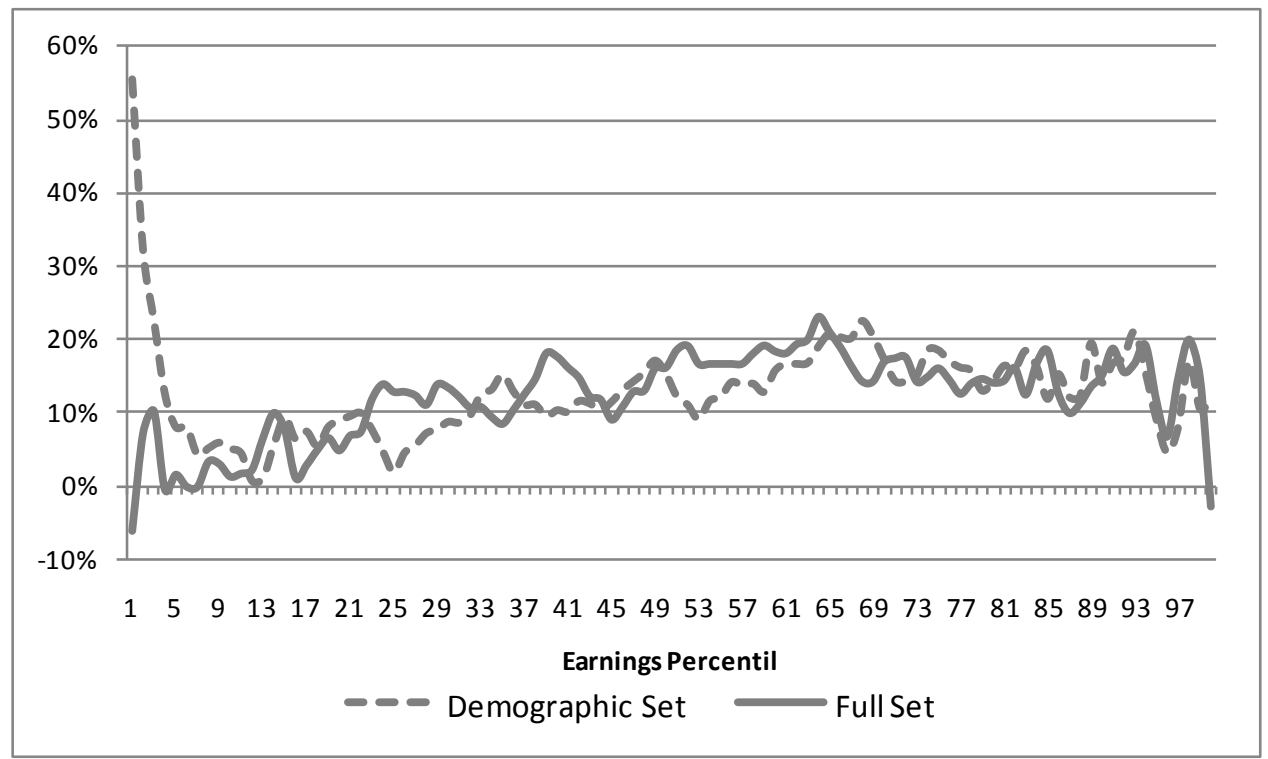

Source: Authors' calculations using Household Surveys (World Bank)

Figure 12. Unexplained Gender Earnings Gap by Percentiles of the Earnings Distribution of Males and Females-Western Europe

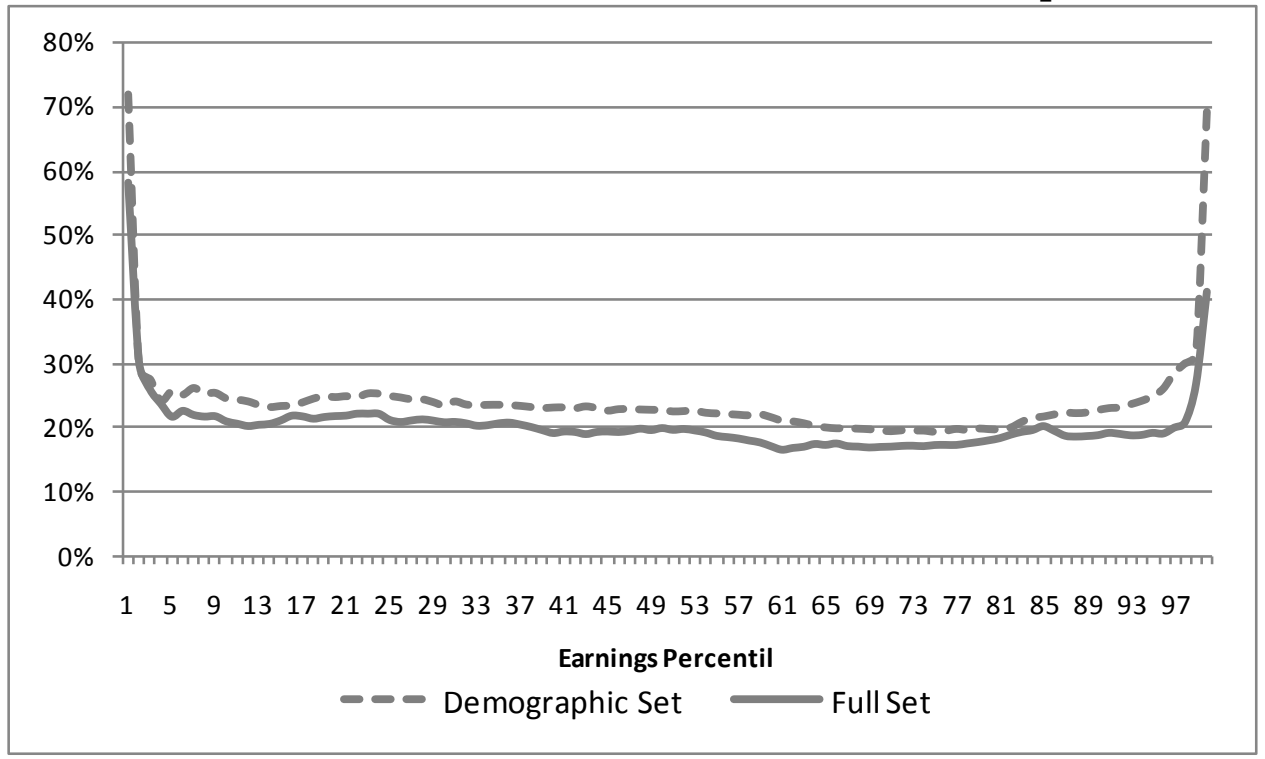

Source: Authors' calculations using Household Surveys (World Bank) 
Table 6 (below) summarizes all the information from Figures 1 to 12 describing the segments of the labor markets for which the unexplained gender earnings gaps are more pronounced. The most salient regularities that can be traced in most of the regions under analysis are two: part-time workers and those with lower educational achievement suffer from the highest unexplained gender earnings gaps. It is interesting to note that this also shows some similarities with respect to Latin America. ${ }^{6}$

Table 6. Labor Market Segments with Highest Unexplained Gender Earnings Gap by Region

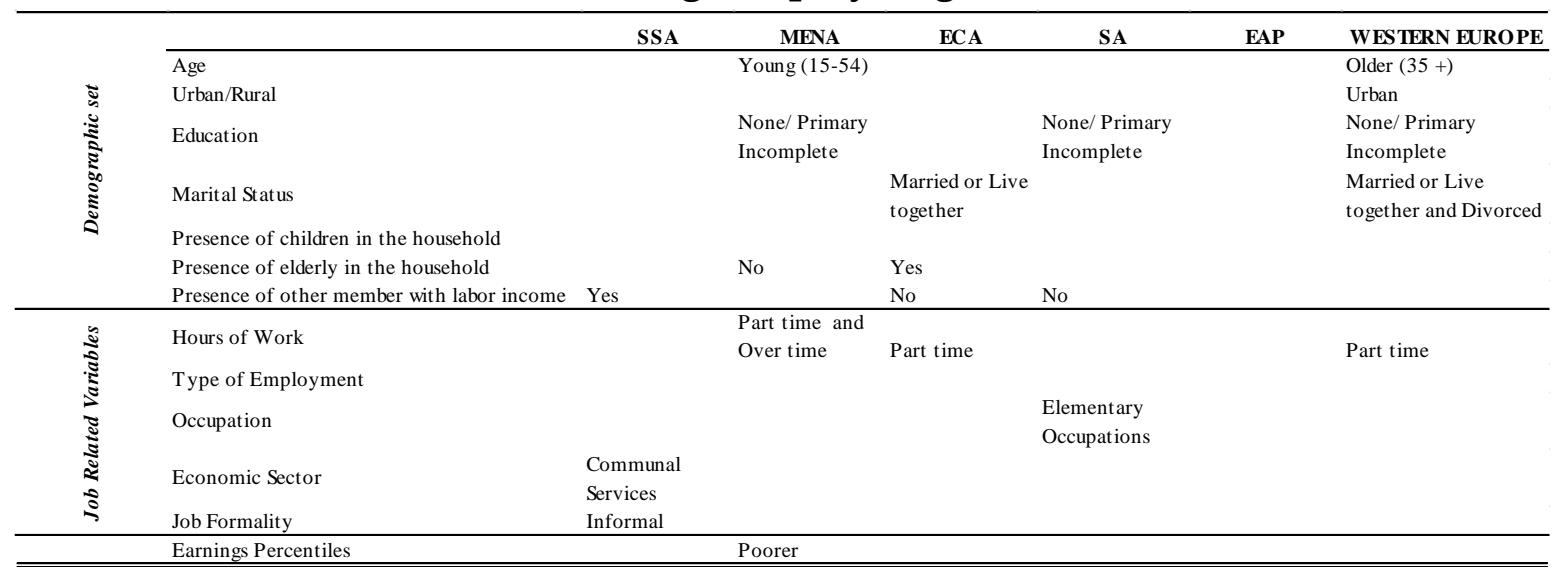

Source: Authors' calculations using Household Surveys (World Bank)

\footnotetext{
${ }^{6}$ See Atal, Nopo and Winder (2009).
} 


\section{Gender Earnings Gap and the Economic, Cultural and Political Characteristics.}

Having shown the heterogeneity on unexplained gender earnings gaps across the world, this section will explore the cross-country linkages of these disparities and other socio-economic and political variables. Figures 13 through 15 illustrate the correlation between the unexplained gender earnings gaps (the one that remains after controlling for the full set of matching variables described above) and GDP per-Capita, Institutionalized democracy and Predominant religion respectively.

- Figure 13 plots GDP per capita, measured in 2005 PPP terms, against the unexplained component of the wage gap. The negative relationship between the two variables that the figure depicts is weak, as judged by the R-squared coefficient (0.0066). Without considering Luxemburg within the analysis the R-squared would increase (0.0377). Bigger economies tend to show smaller gender disparities, but the relationship is not too strong.

- Figure 14 plots Institutionalized Democracy against the unexplained component of the wage gap, showing a positive relationship between both. Countries with more institutionalized democracies tend to show bigger unexplained gender disparities, although, as above, the relationship is not too strong.

- Figure 15 show bar diagrams of the unexplained component of the gender earnings gaps groups by the predominant religion in the countries. The results show no clear pattern. If any, the unexplained gender earnings gaps are slightly higher in Muslim countries than in the rest of the world.

The results from comparing the unconditional gender earnings gaps with the same socio-economic and political indicators (available upon request) deliver similar results. 


\section{Figure 13. Unexplained Component of the Gender Earnings Gap against GDP per}

capita

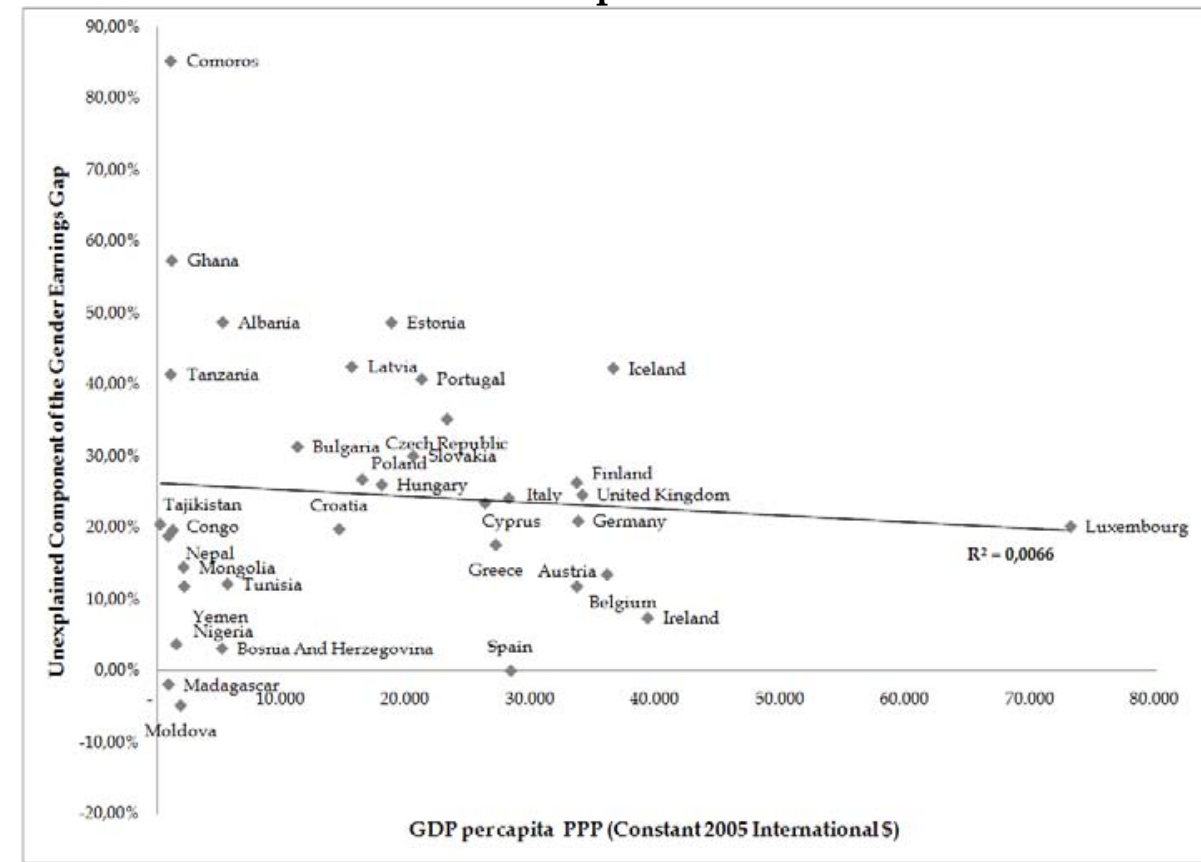

Source: Authors' calculations using World Bank Indicators.

Figure 14. Unexplained Component of the Gender Earnings Gap against Democracy Level

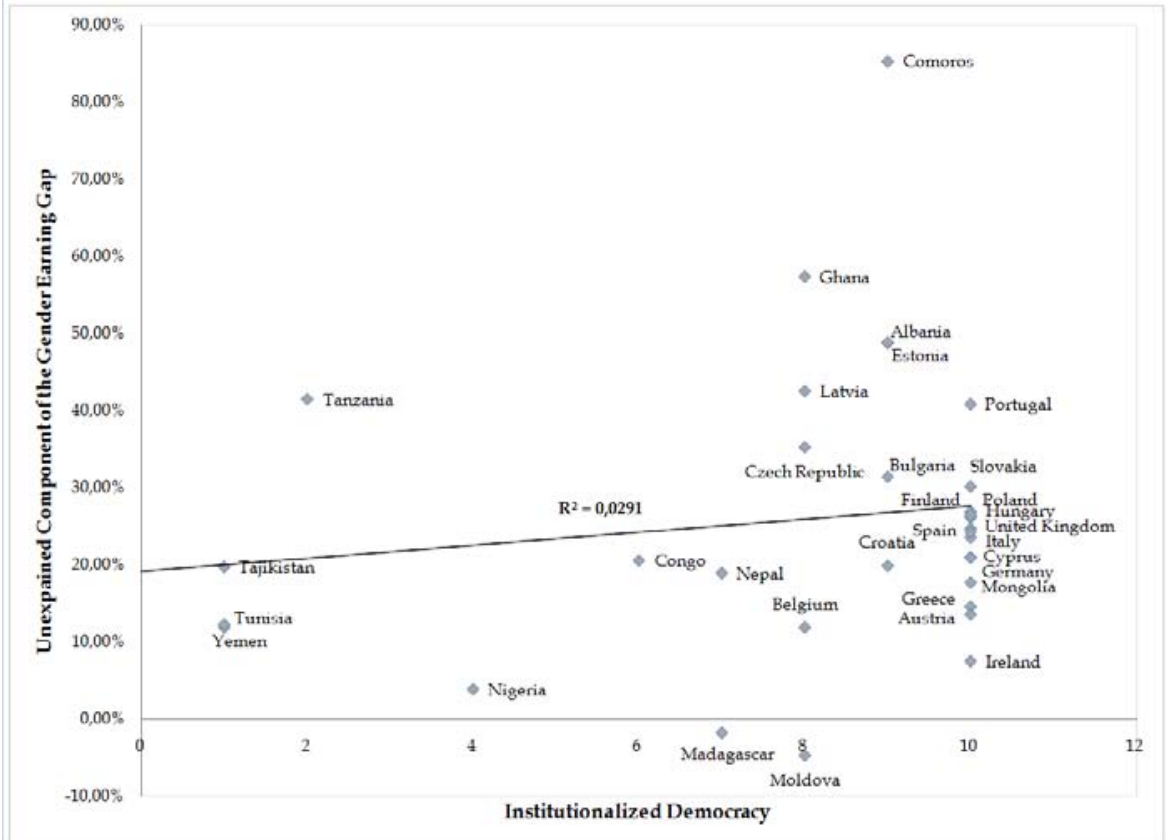

Source: Authors' calculations using Policy IV Indicators.

The Institutionalized Democracy indicator is an eleven-point scale (0-10) derived from indicators on the competitiveness of political participation, the openness and competitiveness of executive recruitment and constraints on the chief executive (See Annex 2 for details) 
Figure 15. Unexplained Component of the Gender Earnings Gap and Religion, by Country

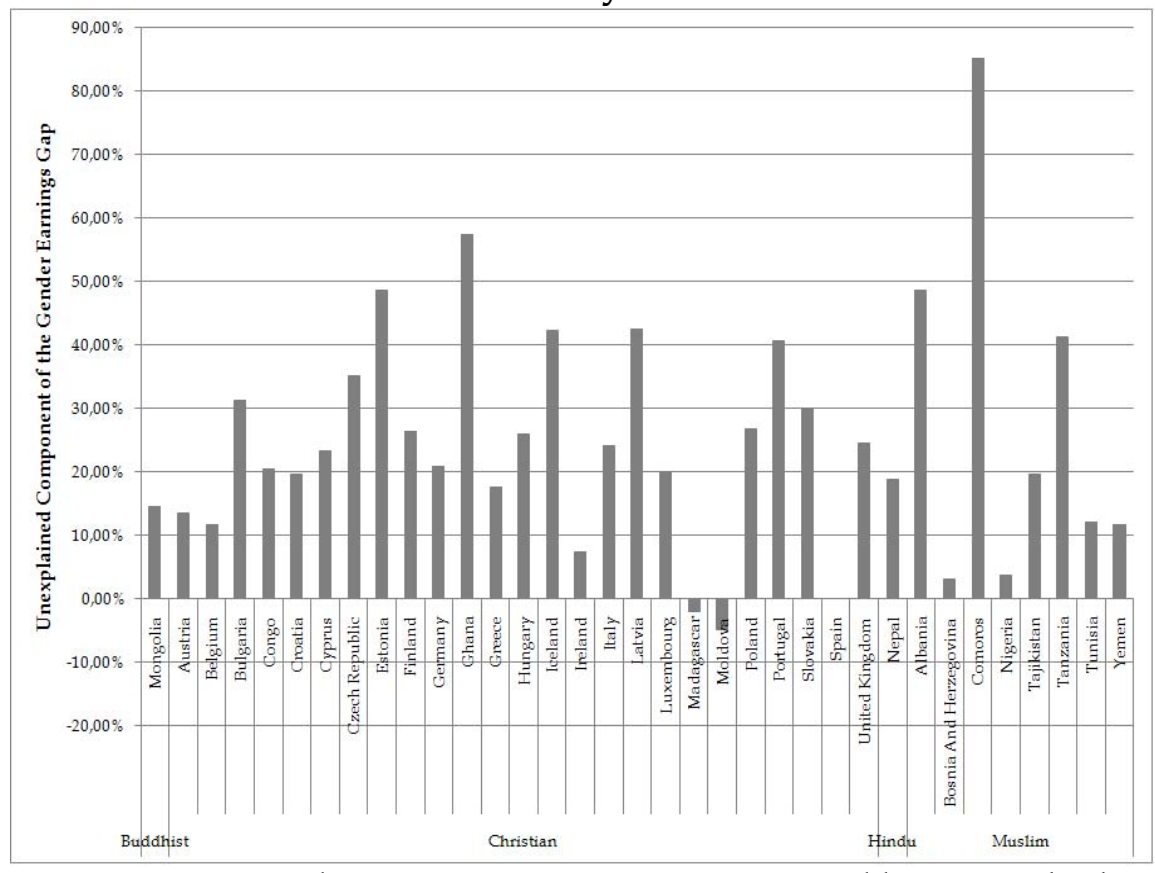

Source: United Nations, CIA World Factbooks. The figure reports the religion that shows the largest group of adherents in each country. 


\section{Concluding Remarks}

This paper has presented gender earnings disparities for an as comprehensive as possible list of countries. A prominent result is the vast heterogeneity of gender differentials. An important component of those earnings differentials cannot be explained on the basis of gender differences in observable characteristics that the labor markets rewards. At a cross-country level, the gaps cannot be completely linked neither to socio-economic nor to political indicators. Much of the earnings gaps are yet to be explained.

Among the regularities that can be observed across the globe highlights the role of part-time work, a predominantly female way of participating in the labor markets which particularly suffers from higher unexplained gender disparities in pay. Another regularity, seen in most of the regions, is the fact that unexplained gender earnings disparities tend to be more pronounced among low-educated workers, and part-time workers. These regularities on the descriptive statistics of gender earnings gaps may serve as indications of areas for which more analytical work, with a stronger emphasis on causality, is needed for advancing the understanding of gender disparities. 


\section{References}

Amuedo-Dorantes, C. and S. de la Rica. 2005. "The Impact of Gender Segregation on MaleFemale Wage Differentials: Evidence from Matched Employer-Employee Data for Spain." IZA Discussion Paper No. 1742. Bonn, Germany: Institute for the Study of Labor (IZA).

Angel-Urdinola, D. and Q. Wodon. Income Generation and Intra-Household Decision Making: A Gender Analysis for Nigeria. En: World Bank. Gender Disparities in Africa's Labor Market. Washington, D.C, United States. World Bank. 2010. p. 381406.

Arumpalam, W., A. L. Booth., \& M. L. Bryan. 2004. “Is There a Glass Ceiling over Europe? Exploring the Gender Wage Gap across the Wages Distribution."IZA Discussion Paper No. 1373. Bonn, Germany: Institute for the Study of Labor (IZA).

Atal, J.P., H. Ñopo and N. Winder. 2009. “New Century, Old Disparities. Gender and Ethnic Wage Gaps in Latin America". Research Department Working Paper 109. Washington, DC, United States: Inter-American Development Bank.

Backiny-Yetna, P. and Q. Wodon. Gender Labor Income Shares and Human Capital Investment in the Republic of Congo. En: World Bank. Gender Disparities in Africa's Labor Market. Washington, D.C, United States. World Bank. 2010. p. 359-379.

Blau F. and L. Kahn. 2001. "Understanding International Difference in the Gender Pay Gap". National Bureau of Economic Research. Working paper 8200.

Brainerd, E. 2000. “Women in Transition: Changes in Gender Wage Differentials in Eastern Europe and then Former Soviet Union". Industrial and Labor Relations Review, Vol. 54, No. 1 (Oct., 2000), pp. 138-162. Cornell University, School of Industrial \& Labor Relations. http://www.jstor.org/stable/2696036.

Calonico, Sebastian and Hugo Nopo. 2009. "Gender segregation in the workplace and wage gaps: evidence from urban Mexico 1994-2004" in Research on Economic Inequality. Vol 17 Editor(s): Yves Flückiger, Sean F. Reardon, Jacques Silber ISBN: 978-1-84855-786-4

Cornish, M. 2007. “Closing The Global Gender Pay Gap: Securing Justice for Women's Work". Comparative Labor Law E Policy Journal 28(2), p. 220

Daly, A. et al. 2006. “The Gender Wage Gap in Four Countries.” IZA Discussion Paper No. 1921. Bonn, Germany: Institute for the Study of Labor (IZA).

Dimova, R and I.N. Gang. 2004. "Self-Selection and Earnings During Volatile Transition". IZA Discussion Paper 1158. Bonn, Germany: Institute for the Study of Labor (IZA).

Dolado, J. J., V. Llorens., S. de la Rica. 2005. “Ceiling and Floors: Gender Wage Gaps by Education in Spain." IZA Discussion Paper No. 1483. Bonn, Germany: Institute for the Study of Labor (IZA).

El-Haddad, A. 2009. "Labor Market Gender Discrimination under Structural Adjustment: The Case of Egypt". SRC/CIDA Research Program on Gender and Work, Working Paper 
series 003. Social Research Center, American University in Cairo, New Cairo Campus. Cairo, Egipto.

Fafchamps, M., M. Sodelbom and N. Benhassine. 2008. "Wage Gaps and Job Sorting in African Manufacturing". ESRC Global Poverty Research Group. United Kingdom.

Hoyos, A. and H. Nopo. 2010. "Evolution of Gender Gaps in Latin America at the Turn of the Twentieth Century: An addendum to "New Century, Old Disparities"'. Research Department Working Paper 176. Washington, DC, United States: InterAmerican Development Bank.

Imbert Clément. 2010. "Decomposing Wage Inequality: Public and Private Sectors in Vietnam 1993-2006". Paris, France: Paris School of Economics.

International Labour Organization (ILO). 2001. Women, Gender and Work. Geneve, Switzerland:ILO.

Kandil Lamia, E. 2009. “Gender Wage Discrimination in Egypt: A Quantile Regression Analysis". Paris: Université Paris I Panthéon-Sorbonne.

Kolev, A. and N. Sirven. Gender Disparities in Africa's Labor Markets: A Cross-Country Comparison Using Standardized Survey Data. En: World Bank. Gender Disparities in Africa's Labor Market. Washington, D.C, United States. World Bank. 2010. p. 2353.

Kolev, A. and P. Suarez Robles. Exploring the Gender Pay Gap Through Different Age Cohorts: The Case of Ethiopia. En: World Bank. Gender Disparities in Africa's Labor Market. Washington, D.C, United States. World Bank. 2010. p. 57-85.

Lehmann, H. and J. Wadsworth. 2001. "Wage Arrears and the Distribution of Earnings in Russia". IZA Discussion Paper 410. Bonn, Germany: Institute for the Study of Labor (IZA).

Liu, A. Y. C. 2001. "Gender Wage Gap in Transition in Vietnam." International and Development Economics Working Papers idec01-3. Canberra, Australia: The Australian National University.

---. 2003. "Gender Wage Gap in Vietnam." International and Development Economics Working Papers idec03-5. Canberra, Australia: The Australian National University.

Meng, X. 1998. “The Economic Position of Women in Asia”. CLARA Working Paper, No. 4. Amsterdam, Holanda: IIAS/IISG.

Montenegro, C. and Hirn M.L. 2008. "A New Disaggregated Set of Labor Market Indicators Using Standardized Household Surveys from Around the World". Background paper, World Development Report. Washington DC, World Bank.

Newell, A. and R. Barry. 2001. "The Gender Pay Gap in the Transition from Communism: Some Empirical Evidence". IZA Discussion Paper 268. Bonn, Germany: Institute for the Study of Labor (IZA).

Niimi, Y. 2009. "Gender Equality and Inclusive Growth in Developing Asia". ADB Economics Working Paper Series No. 186. Metro Manila, Philippines: Asian Development Bank. 
Niimi, Yoko. 2009. “Gender Equality and Inclusive Growthin Developing Asia." Economics Working Paper Series No. 186. Mandaluyong City, Phillipinnes: Asian Development Bank.

Nordman, C.J., F. Rakotomanana and A.S. Robilliard. Gender Disparities in the Malagasy Labor Market. En: World Bank. Gender Disparities in Africa's Labor Market. Washington, D.C, United States. World Bank. 2010. p. 87-153.

Nordman, C. and F.C. Wolff . 2006. "Is There a Glass Ceiling in Morocco? Evidence from Matched Worker-Firm Data”. Paris, France: LEN, Faculté des Sciences Économiques, Université de Nantes.

Nordman, C.J. and F. C. Wolff. Gender Differences in Pay in African Manufacturing Firms. En: World Bank. Gender Disparities in Africa's Labor Market. Washington, D.C, United States. World Bank. 2010. p. 155-191.

Nopo, H. 2006. “The Gender Wage Gap in Chile 1992-2003 from a Matching Comparisons Perspective." Research Department Working Paper 562. Washington, DC, United States: Inter-American Development Bank.

---. 2008. "Matching as a Tool to Decompose Wage Gaps." Review of Economics and Statistics 90(2): 290-299.

Olivetti, C. and B. Petrongolo. 2006. “Unequal Pay or Unequal Unemployment? A CrossCountry Analysis of Gender Gaps. IZA Discussion Paper No. 1941. Bonn, Germany: Institute for the Study of Labor (IZA).

Ostendorp, R. H. et al. 2006. "Returns to Education and the Gender Wage Gap in Vietnam." Amsterdam, The Netherlands: Free University Amsterdam, Tinbergen Institute.

Parra Osorio, J. P. and Q. Wodon. Gender, Time Use, and Labor Income in Guinea: Micro and Macro Analyses. En: World Bank. Gender Disparities in Africa's Labor Market. Washington, D.C, United States. World Bank. 2010. p. 231-271.

----. How Does Growth Affect Labor Income by Gender? A Structural Path Analysis for Tanzania. En: World Bank. Gender Disparities in Africa's Labor Market. Washington, D.C, United States. World Bank. 2010. p. 273-296.

Pastore, Francesco. 2010. “The Gender Gap in Early Career in Mongolia." International Journal of Manpower 31(2):188-207.

Pham, T. H., B. Reilly. 2006. “The Gender Pay Gap in Vietnam, 1993-2002: A Quantile Regression Approach." PRUS Working Paper No. 34.

Plasman, R. and S. Sissoko. 2004. "Comparing Apples with Oranges: Revisiting the Gender Gap in an International Perspective." IZA Discussion Paper No. 1449. Bonn, Germany: Institute for the Study of Labor (IZA).

Ricardo Hausmann, L. D. Tyson and S. Zahidi. 2010. “The Global Gender Gap Report” World Economic Forum. Geneva, Switzerland. 
Rückert, E. 2002. “Decomposing Estonian Wages by Gender: A Quantile Regression Approach of the Juhn, Murphy and Pierce Methodology". Centre for Economic Reform and Transformation. Edinburgh: Heriot-Watt University School of Management.

Ruggeri Laderchi, C., H. Lofgren and R. Abdula. Addressing Gender Inequality in Ethiopia: Trends, Impacts, and the Way Forward. En: World Bank. Gender Disparities in Africa's Labor Market. Washington, D.C, United States. World Bank. 2010. p. 193-227.

Simón, H. 2007. "The Gender Pay Gap in Europe: An International Comparison with Matched Employer-Employee Data." Alicante, Spain: Universidad de Alicante.

Son, H. H. 2007. "Occupational Segregation and Gender Discrimination in Labor Markets: Thailand and Viet Nam". Working Paper Series No. 108. Mandaluyong City, Phillipinnes: Economics and Research Department, Asian Development Bank.

Suárez Robles, P. Gender Disparities in Time Allocation, Time Poverty, and Labor Allocation Across Employment Sectors in Ethiopia. En: World Bank. Gender Disparities in Africa's Labor Market. Washington, D.C, United States. World Bank. 2010. p. 299-332.

Tansel. A. 2004. "Public-Private Employment Choice, Wage Differentials and Gender in Turkey". IZA Discussion Paper 1262. Bonn, Germany: Institute for the Study of Labor (IZA).

Thomas Hertz, Paul Winters, A. P. de la O, E. J. Quiñones, B. Davis and A. Zezza. 2008. "Wage Inequality In International Perspective: Effects of Location, Sector, And Gender" ESA Working Paper No. 08-08.

Tzannatos, Z. 1999. “Women And Labor Market Changes In The Global Economy: Growth Helps, Inequalities Hurt and Public Policy Matters". The World Bank. Elsevier Science.

Wagle Udaya, R. 2007 "Are Economic Liberalization and Equality Compatible? Evidence from South Asia”. World Development Vol. 35, No. 11, pp. 1836-1857. Michigan, USA: Western Michigan University, Kalamazoo.

Weichselbaumer, D., R. Winter-Ebmer and M. Zweimüller. 2007. “Market Orientation and Gender Wage Gaps: An International Study". Department of Economics Johannes Kepler University of Linz.

Wodon, Q and Y. Ying. Domestic Work Time in Sierra Leone. En: World Bank. Gender Disparities in Africa's Labor Market. Washington, D.C, United States. World Bank. 2010. p. 333-356.

World Bank. Gender Equality in East Asia: Progress, and the Challenges of Economic Growth and Political Change. East Asia Update. Washington, D.C, United States: World Bank. Availabe at:

http://siteresources.worldbank.org/INTEAPHALFYEARLYUPDATE/Resources/g enderequality.pdf. 
Zweimüller, M., R. Winter-Ebmer and D. Weichselbaumer. 2007. “Market Orientation and Gender Wage Gaps: An International Study". Department of Economics Johannes Kepler University of Linz. Working Paper No. 0712. 
Annex 1.

Region Literature Review

\begin{tabular}{|c|c|c|c|c|}
\hline Country & $\begin{array}{l}\text { Authors } \\
\text { and Year }\end{array}$ & Data & Main Findings & Methodology \\
\hline \multicolumn{5}{|c|}{ INTERNATIONAL COMPARISON } \\
\hline $\begin{array}{c}124 \text { countries in } \\
\text { East \& Southern } \\
\text { Africa } \\
\text { West Africa } \\
\text { East Asia Pacific, } \\
\text { South Asia, } \\
\text { East \& Central } \\
\text { Europe, } \\
\text { Rest of Europe, } \\
\text { Middle East, } \\
\text { North Africa, } \\
\text { Americas }\end{array}$ & $\begin{array}{c}\text { Tzannatos } \\
\text { (1999) }\end{array}$ & ILO Data Base & $\begin{array}{l}\text { The paper examines the level and changes in female and male participation rates, } \\
\text { employment segregation and female relative to male wages across the world economy. It is } \\
\text { presented a decomposition of the economy-wide female relative wage in employment } \\
\text { effect (changes in sectoral employment), female wage effect (changes in gender pay gap } \\
\text { within sectors) and structural wage effect (changes in male earnings). } \\
\text { It finds sufficient evidence supporting that labor markets in developing countries are } \\
\text { transformed in the sense that gender differentials in employment and pay are narrowing } \\
\text { much faster than in industrialized. Growth benefits women at large, inequalities can have } \\
\text { significantly adverse effects on welfare, and market-based development alone can be a } \\
\text { weak instrument for reducing inequality. }\end{array}$ & $\begin{array}{l}\text { Decomposition } \\
\text { of the } \\
\text { economy-wide } \\
\text { female relative } \\
\text { wage. }\end{array}$ \\
\hline \multirow[t]{2}{*}{$\begin{array}{c}\text { Australia, Austria, } \\
\text { Britain, Bulgaria, } \\
\text { Canada, Czech } \\
\text { Republic, East } \\
\text { Germany, West } \\
\text { Germany, } \\
\text { Hungary, Ireland, } \\
\text { Israel, Italy, Japan, } \\
\text { Netherlands, New } \\
\text { Zealand, Norway, } \\
\text { Poland, Russia, } \\
\text { Slovenia, Sweden, } \\
\text { Switzerland, USA. }\end{array}$} & $\begin{array}{l}\text { Blau and } \\
\text { Kahn } \\
(2001)\end{array}$ & $\begin{array}{l}\text { International } \\
\text { Survey } \\
\text { Programme }\end{array}$ & $\begin{array}{l}\text { Using micro-data for } 22 \text { countries over } 1985-94 \text { period, it was found that more compressed } \\
\text { male wage structures and lower female net supply are both associated with lower gender } \\
\text { pay gap. The extent of collective bargaining coverage in each country is significantly } \\
\text { associated with the gender pay gap. Moreover, a large part of the difference in the gender } \\
\text { differential between high gap and low gap countries is explained by the differences across } \\
\text { these countries in overall wage structure, and in the differences in female net supply. } \\
\text { The Juhn, Murphy and Pierce decomposition suggested a strong role for wage inequality } \\
\text { and wage setting institutions in affecting gender pay gap. }\end{array}$ & $\begin{array}{l}\text { Juhn, Murphy } \\
\text { and Pierce } \\
\text { decomposition }\end{array}$ \\
\hline & $\begin{array}{l}\text { Cornish, } \\
(2007)\end{array}$ & & $\begin{array}{l}\text { It is estimated that women earn about } 78 \% \text { of what men make. The principal reasons for } \\
\text { the existence of gender pay discrimination are the occupational segregation and the global } \\
\text { trend towards greater informality arising from market liberalization. For the most part of } \\
\text { the world, existing labor market mechanisms have not made significant progress in } \\
\text { remedying this global gender pay gap. Measures that can deliver increases in women's pay } \\
\text { to reduce this discrimination are critical to their survival and prosperity. }\end{array}$ & Article \\
\hline $\begin{array}{l}\text { Meta-analysis: } 62 \\
\text { countries; } \\
\text { Micro-data: } 58 \\
\text { countries. }\end{array}$ & $\begin{array}{l}\text { Weichselba } \\
\text { umer, } \\
\text { Winter- } \\
\text { Ebmer and }\end{array}$ & $\begin{array}{l}\text { Meta-analysis } \\
\text { conducted by } \\
\text { Weichselbaum } \\
\text { er and Winter- }\end{array}$ & $\begin{array}{l}\text { It is used two very different approaches to explore the relation between market orientation } \\
\text { and gender wage differentials in international data. The first approach employs meta- } \\
\text { analysis data and takes advantage of the fact that many studies already exist which use } \\
\text { national data sources to the best possible extent. The second approach uses comparable }\end{array}$ & $\begin{array}{c}\text { Oaxaca- } \\
\text { Blinder } \\
\text { decomposition }\end{array}$ \\
\hline
\end{tabular}




\begin{tabular}{|c|c|c|c|c|}
\hline & $\begin{array}{c}\text { Zweimüller. } \\
\text { (2007) }\end{array}$ & $\begin{array}{c}\text { Ebmer } \\
(2005) ; \\
\text { International } \\
\text { Social Survey } \\
\text { Programme } \\
\text { (ISSP) } \\
1885-2000\end{array}$ & $\begin{array}{l}\text { micro data. In each cases, it is calculated the gender earning gap using Oaxaca- Blinder } \\
\text { decomposition. Using both data bases, it is obtained the conclusion about the existence of a } \\
\text { strong negative correlation between competitive markets and gender wage gaps, in } \\
\text { particular when competitive markets are measured by the components "free trade", } \\
\text { "absence of regulation" and "legal structure". More market orientation might be related to } \\
\text { gender wage gaps via its effects on competition in product and labor markets and the } \\
\text { general absence of regulation in the economy. }\end{array}$ & \\
\hline $\begin{array}{l}\text { Sub-Saharan: } \\
\text { Ghana, Malawi, } \\
\text { Nigeria; } \\
\text { South \& East Asia: } \\
\text { Bangladesh, } \\
\text { Indonesia, Nepal, } \\
\text { Vietnam; } \\
\text { Eastern Europe \& } \\
\text { Central Asia: } \\
\text { Albania, Bulgaria, } \\
\text { Tajikistan: } \\
\text { Latin American } \\
\text { and the Caribbean: } \\
\text { Ecuador } \\
\text { Guatemala } \\
\text { Nicaragua } \\
\text { Panama }\end{array}$ & $\begin{array}{c}\text { Hertz, } \\
\text { Winters, de } \\
\text { la O, } \\
\text { Quiñones, } \\
\text { Davis Zezza } \\
\text { (2008). }\end{array}$ & RIGA-L dataset & $\begin{array}{l}\text { It is used the Oaxaca-Blinder decomposition to understand the determinants of wage-gaps } \\
\text { between men and women, between urban and rural workers, and between those employed } \\
\text { in the rural agricultural versus the rural non-agricultural sectors, for the } 14 \text { developing and } \\
\text { transition economies. The average gender gap in daily wages across the } 14 \text { countries was } \\
\text { on the order of } 25 \text { percent in favor of men. There was no clear regional pattern to the size of } \\
\text { the raw wage difference, yet there is a clear regional difference in the breakdown between } \\
\text { its explained and unexplained components. The average unexplained share of the wage } \\
\text { gap was very high, at roughly } 90 \text { percent. While the geographic and sectorial wage gaps } \\
\text { should respond to changes in the level of human capital, and in the location of nonfarm } \\
\text { employment opportunities, in other words, to economic development, there seems to be no } \\
\text { evidence that the gender wage premium responds to economic growth per se. }\end{array}$ & $\begin{array}{l}\text { Oaxaca-Blinder } \\
\text { decomposition }\end{array}$ \\
\hline \multicolumn{5}{|c|}{ SSA } \\
\hline $\begin{array}{l}\text { Cote } \\
\text { D'ivoire, } \\
\text { Ethiopia, } \\
\text { Kenya, } \\
\text { Cameroon, } \\
\text { Ghana, } \\
\text { Madagascar, } \\
\text { Mauritania, } \\
\text { Malawi, } \\
\text { Nigeria, } \\
\text { Uganda }\end{array}$ & $\begin{array}{l}\text { Kolev and } \\
\text { Sirven }\end{array}$ & $\begin{array}{c}\text { World Bank } \\
\text { Survey-based } \\
\text { Harmonized } \\
\text { Indicators } \\
\text { Program } 2000\end{array}$ & $\begin{array}{l}\text { Participation in productive employment in urban areas was appreciably lower for women, } \\
\text { yet countries with more favorable employment outcomes for men also had higher } \\
\text { employment ratios among women and less gender disparities in employment. In most } \\
\text { countries. Unemployment was largely an urban phenomenon, affecting women } \\
\text { disproportionately. Women were overrepresented among the underemployed. Low-paid } \\
\text { work was an important issue in seven countries for which data were available, affecting } \\
\text { both men and women. In most countries, women experienced a disadvantage in earnings. } \\
\text { Women tended to be underrepresented in the industry and service sectors and } \\
\text { overrepresented in agriculture. For both men and women, education did not seem to be } \\
\text { associated with lower unemployment and higher employment. The returns from education } \\
\text { on earnings were important, and education also had a positive effect on gender wage } \\
\text { equity. }\end{array}$ & $\begin{array}{l}\text { Ratios and } \\
\text { Indicators }\end{array}$ \\
\hline
\end{tabular}




\begin{tabular}{|c|c|c|c|c|}
\hline Ethiopia & $\begin{array}{l}\text { Kolev and } \\
\text { Suarez }\end{array}$ & $\begin{array}{l}\text { Labor Force } \\
\text { Survey } 2005\end{array}$ & $\begin{array}{l}\text { On average women's monthly wages represented in } 2005 \text { only about } 55 \text { percent of men's } \\
\text { wages. No more than } 50 \text { percent of the observed wage gap could be attributed to } \\
\text { explained differences in characteristics, leaving a large fraction of the gap unexplained. A } \\
\text { non-negligible proportion of the gender wage gap - at least } 11 \text { percent but no more than } 23 \\
\text { percent on average-was explained by the differences in education endowments between } \\
\text { men and women. Job characteristics were found to be systematically less favorable for } \\
\text { women. }\end{array}$ & $\begin{array}{l}\text { Mincer } \\
\text { equations, } \\
\text { Cotton- } \\
\text { Neumark } \\
\text { decomposition } \\
\text { procedure }\end{array}$ \\
\hline Madagascar & $\begin{array}{l}\text { Nordman, } \\
\text { Rakotoma } \\
\text { nana, and } \\
\text { Robilliard }\end{array}$ & $\begin{array}{l}\text { Enquête } \\
\text { périodique } \\
\text { auprès des } \\
\text { ménages } \\
\text { (EPM) } 2001 \\
\text { and } 2005\end{array}$ & $\begin{array}{l}\text { Regarding labor allocation, participation of women in the Malagasy labor market appears } \\
\text { to be high, and it increased between } 2001 \text { and } 2005 \text {. Overall, the structure of employment } \\
\text { changed between } 2001 \text { and } 2005 \text {. The evolution in employment status can be explained in } \\
\text { part by some of the shocks experienced by the Malagasy labor market between } 2001 \text { and } \\
2005 \text {. The study found a strong positive impact of education on the probability of getting a } \\
\text { paid job, for both men and women. Regarding gender inequality in earnings, the results } \\
\text { show that the average gender wage gap is relatively small and stable over time. Across } \\
\text { wage employment sectors, the gender gap appears to be lowest in the public sector and } \\
\text { highest in the informal sector. }\end{array}$ & $\begin{array}{c}\text { Oaxaca and } \\
\text { Neumark's } \\
\text { Decomposition }\end{array}$ \\
\hline $\begin{array}{l}\text { Benin, } \\
\text { Kenya, } \\
\text { Madagascar, } \\
\text { Mauritius, } \\
\text { Morocco, } \\
\text { Senegal, and } \\
\text { Uganda } \\
\end{array}$ & $\begin{array}{l}\text { Nordman } \\
\text { and Wolff }\end{array}$ & $\begin{array}{l}\text { Investment } \\
\text { Climate } \\
\text { Assessment } \\
\text { (ICA) surveys }\end{array}$ & $\begin{array}{l}\text { This study makes use of matched employer-employee data collected in seven African } \\
\text { countries to shed light on the magnitude of the gender wage gap in the manufacturing } \\
\text { sector. Raw gender gaps calculated at the mean of the samples tend to hide significant } \\
\text { differences in the magnitude of the gaps along the wage distribution. They investigated the } \\
\text { belief that differences among the seven African countries might be a result of the presence } \\
\text { of selectivity effects, through gender differences in access to jobs. }\end{array}$ & $\begin{array}{l}\text { Quantile } \\
\text { regression, } \\
\text { Fields } \\
\text { decomposition, } \\
\text { Mean and } \\
\text { quantile } \\
\text { decomposition }\end{array}$ \\
\hline Tanzania & $\begin{array}{l}\text { Parra and } \\
\text { Wodon }\end{array}$ & $\begin{array}{l}\text { SAM } 2001 \\
\text { constructed } \\
\text { by Thurlow } \\
\text { and Wobst } \\
\quad(2003)\end{array}$ & $\begin{array}{l}\text { An exogenous increase in the demand for any of the six sectors would help (at the margin) } \\
\text { to close the gap between total pay for male and female workers, and between total pay for } \\
\text { educated and non-educated workers. Results would suggest that promoting value added } \\
\text { growth in Tanzania could help close the gap between female and male labor income. }\end{array}$ & $\begin{array}{l}\text { Structural Path } \\
\text { Analysis (SPA) } \\
\text { on Social } \\
\text { accounting } \\
\text { matrices } \\
\text { (SAMs) }\end{array}$ \\
\hline
\end{tabular}




\begin{tabular}{|c|c|c|c|c|}
\hline Ethiopia & Suárez & $\begin{array}{c}\text { Labor Force } \\
\text { Survey (LFS) } \\
2005\end{array}$ & $\begin{array}{l}\text { There is a strong gender-based division of labor in Ethiopia, which is much more acute in } \\
\text { rural areas. Women work more and for longer hours than men in the household, while the } \\
\text { reverse is true in the labor market. Women spend more time at work than men, this } \\
\text { phenomenon being observed to a greater extent in rural areas. Women are clearly } \\
\text { disadvantaged in terms of job allocation. Unpaid family workers account for the highest } \\
\text { share of female workers, while the majority of male workers are self-employed. As they } \\
\text { become educated and reach higher levels of education, men and, to a greater extent, } \\
\text { women, strongly increase their chances of working in the public sector, which is the most } \\
\text { rewarding wage-employment sector because it offers the highest earnings and protection. }\end{array}$ & $\begin{array}{l}\text { Descriptive } \\
\text { Statistics, } \\
\text { Multinomial } \\
\quad \text { logit } \\
\text { regressions, } \\
\text { tobit models }\end{array}$ \\
\hline Sierra Leone & $\begin{array}{l}\text { Wodon } \\
\text { and Ying }\end{array}$ & $\begin{array}{c}\text { Integrated } \\
\text { Household } \\
\text { Survey }\end{array}$ & $\begin{array}{l}\text { Women are found to work much more than men on domestic tasks, especially in rural } \\
\text { areas. For many children, the burden of domestic work is high as well, reaching more than } \\
20 \text { hours per week on average in some cases. Access to basic infrastructure services (water } \\
\text { and electricity) makes a large difference in the amount of time spent on domestic work. }\end{array}$ & $\begin{array}{c}\text { Descripitive } \\
\text { Statistics, OLS }\end{array}$ \\
\hline $\begin{array}{l}\text { Republic of } \\
\text { Congo }\end{array}$ & $\begin{array}{l}\text { Backiny- } \\
\text { Yetna and } \\
\text { Wodon }\end{array}$ & $\begin{array}{l}\text { Households } \\
\text { Expenditure } \\
\text { (ECOM) } \\
\text { survey }\end{array}$ & $\begin{array}{l}\text { Labor income tends to be controlled by men. The results presented here show that, when } \\
\text { women control a higher share of total labor income within the household, the household } \\
\text { tends to allocate larger shares of its resources to investments that benefit their children. The } \\
\text { evidence here suggests that in the Republic of Congo, as in other countries, the unitary } \\
\text { household hypothesis does not hold well. }\end{array}$ & $\begin{array}{l}\text { Descriptive } \\
\text { Statistics, } \\
\text { Standard } \\
\text { Regression } \\
\text { Analysis }\end{array}$ \\
\hline Nigeria & $\begin{array}{l}\text { Urdinola } \\
\text { and uentin } \\
\text { Wodon }\end{array}$ & $\begin{array}{l}\text { Core Welfare } \\
\text { Questionnaire } \\
\text { Indicator } \\
\text { (CWIQ) } \\
\text { surveys 2003 }\end{array}$ & $\begin{array}{l}\text { Most of household decisions are made by men. Women participate more often in decisions } \\
\text { on expenditures for food, heath, and education, but even in these areas, men more often } \\
\text { than not remain the main decision makers. The decision-making power of women is } \\
\text { especially low among poor households, in part, because in such households, the likelihood } \\
\text { that women will be the main contributor of household income is much lower as well. This } \\
\text { study found that increasing the contribution ability of women to household income leads } \\
\text { to higher decision-making power for them within the household. }\end{array}$ & $\begin{array}{c}\text { Bivariate probit } \\
\text { techniques }\end{array}$ \\
\hline \multicolumn{5}{|c|}{ MENA } \\
\hline Egypt & $\begin{array}{c}\text { El-Haddad } \\
(2009)\end{array}$ & $\begin{array}{l}\text { Egyptian } \\
\text { Labor Market } \\
\text { Survey } 1998 \\
\text { and } 2006\end{array}$ & $\begin{array}{l}\text { Egypt's labor market structure is dominated by the divide between the public and private. } \\
\text { The country's labor market changed as a result of the Economic Reform and Structural } \\
\text { Adjustment Program (ERSAP) in 1991. Job quality in Egypt is higher for women than men } \\
\text { due to their higher relative employment share in the public sector. Real monthly wages are } \\
\text { consistently higher for men than women. }\end{array}$ & $\begin{array}{c}\text { Oaxaca } \\
\text { decomposition. }\end{array}$ \\
\hline
\end{tabular}




\begin{tabular}{|c|c|c|c|c|}
\hline Egypt & $\begin{array}{l}\text { Kandil } \\
(2009)\end{array}$ & $\begin{array}{l}\text { Labour } \\
\text { Market } \\
\text { Survey } 1988 \\
\text { and 1998; } \\
\text { Labour } \\
\text { Market Panel } \\
\text { Survey } 2006\end{array}$ & $\begin{array}{l}\text { The overall gender wage gap and discrimination in absolute term are far from being } \\
\text { constant along the wage distribution. Although relative discrimination decreases along the } \\
\text { wage distribution, contribution of discrimination in explaining the gender wage gap rises } \\
\text { during the three years even at the top of the wage distribution. It seems that the increase } \\
\text { in the skills of the labour force, especially for women, did not lead to a reduction for } \\
\text { neither absolute nor relative discrimination. }\end{array}$ & \begin{tabular}{|} 
Two Stage \\
Regression \\
Quantiles \\
(2SRQ), \\
Oaxaca-Blinder \\
decomposition; \\
Machado and \\
Mata \\
methodology
\end{tabular} \\
\hline Morroco & $\begin{array}{l}\text { Nordman } \\
\text { and Wolff } \\
(2006)\end{array}$ & $\begin{array}{l}\text { Firm Analysis } \\
\text { and } \\
\text { Competitiven } \\
\text { ess Survey } \\
\text { (FACS) } 2000\end{array}$ & $\begin{array}{l}\text { There exists a glass ceiling effect in manufacturing firms of Morocco, the earnings gap } \\
\text { being much higher at the top of the distribution than at the bottom. The gender earnings } \\
\text { gap seems to be mainly due to differences in observed characteristics between men and } \\
\text { women at every level of the earnings distribution. Within firms where women and men } \\
\text { have identical labor market characteristics, females are less rewarded for their observed } \\
\text { endowments than males are and this is all the more true when they reach top positions. }\end{array}$ & $\begin{array}{l}\text { Quantile s } \\
\text { regressions, } \\
\text { Quantile } \\
\text { decomposition }\end{array}$ \\
\hline \multicolumn{5}{|c|}{ ECA } \\
\hline $\begin{array}{l}\text { Italy, Spain, } \\
\text { Portugal, the } \\
\text { Netherlands, } \\
\text { the Czech } \\
\text { Republic, } \\
\text { Latvia, } \\
\text { Slovakia, } \\
\text { Lithuania } \\
\text { and Norway }\end{array}$ & Simón & $\begin{array}{c}\text { European } \\
\text { Structure of } \\
\text { Earnings } \\
\text { Survey (2002) }\end{array}$ & $\begin{array}{l}\text { Female segregation into low-wage structures emerges as the main contributor to the } \\
\text { gender pay gap, with female segregation into low-wage workplaces as an outstanding } \\
\text { origin of both the gender pay gap in all European economies and of international } \\
\text { differences in its size. International disparities in global characteristics of the wage } \\
\text { structure, and in particular in the extent of wage inequality, are not major determinants of } \\
\text { inter-country differences in the size of the gender wage gap in Europe. Policy initiatives } \\
\text { like wage formation systems with the aim of influencing the wage structure might not be } \\
\text { central in order to reduce the gender pay gap. Cross-country differences in the origin and } \\
\text { the magnitude of the gender gap in pay are particularly significant between the new } \\
\text { members of the European Union, which suggests the existence of a remarkable diversity } \\
\text { into this group of countries. }\end{array}$ & $\begin{array}{c}\text { Extension of } \\
\text { the Juhn et al. } \\
\text { decomposition. }\end{array}$ \\
\hline Estonia & $\begin{array}{c}\text { Ruckert } \\
\text { (2002) }\end{array}$ & $\begin{array}{c}\text { Estonian } \\
\text { Labour Force } \\
\text { Survey (1995, } \\
1999)\end{array}$ & $\begin{array}{l}\text { The increase of the Estonian gender wage gap of approximately } 7 \% \text { was decomposed into } \\
\text { four components. It was found that the main cause for the increase in the pay differential is } \\
\text { the absence of improvement of the position of women within the male residual } \\
\text { distribution. However, the magnitude of the influence of this so-called "Gap effect" on the } \\
\text { change in the pay differential was reduced by the counteracting sum of the wage structure } \\
\text { components. In other words, the fall in observed wage inequality between } 1995 \text { and } 1999 \\
\text { has a negative impact on the widening of the gender gap. It was shown that the wage gaps }\end{array}$ & $\begin{array}{l}\text { Extension of } \\
\text { the Juhn et al. } \\
\text { decomposition } \\
\text { using quantile } \\
\text { regression } \\
\text { approach. }\end{array}$ \\
\hline
\end{tabular}




\begin{tabular}{|c|c|c|c|c|}
\hline & & & $\begin{array}{l}\text { between men and women for both years increase in size as we move up the wage } \\
\text { distribution. Performing the Juhn et al. decomposition at different quantiles for both years } \\
\text { reveals that the magnitude of the gender specific and wage structure effects are not } \\
\text { homogeneous across the distribution. }\end{array}$ & \\
\hline $\begin{array}{l}\text { Bulgaria, } \\
\text { Czech } \\
\text { Republic, } \\
\text { Hungary, } \\
\text { Khazakstan, } \\
\text { Latvia, } \\
\text { Poland, } \\
\text { Russia, } \\
\text { Slovakia, } \\
\text { Ukraina, } \\
\text { Uzbekistan, } \\
\text { Yugoslavia }\end{array}$ & $\begin{array}{l}\text { Newell } \\
\text { and Reilly } \\
(2001)\end{array}$ & $\begin{array}{l}\text { Bulgarian Household } \\
\text { Budget Survey, Social } \\
\text { Stratification Surveys, } \\
\text { Polish Labour Force } \\
\text { Surveys, FRY Labour } \\
\text { Forree Surveys, Latvian } \\
\text { Household Budget } \\
\text { Survey, Russian } \\
\text { Longitudinal } \\
\text { Monitoring Surveys, } \\
\text { Unraine Living } \\
\text { Standards } \\
\text { Measurement Survey, } \\
\text { Kazakhstan Labour } \\
\text { Force Survey, The } \\
\text { European University } \\
\text { Institute and Essex } \\
\text { University Survey in } \\
\text { Uzbekistan }\end{array}$ & $\begin{array}{l}\text { The gender pay gap has not exhibited, in general, an upward tendency over the } \\
\text { transitional period to which available data relate. Most of the gender pay gap is ascribed to } \\
\text { the 'unexplained' component using conventional decompositions and this may partly be } \\
\text { attributable to the proxy measure for labour force experience used in this study. Quantile } \\
\text { regression analysis indicates that, in all but one country, the ceteris paribus gender pay gap } \\
\text { rises as we move up the wage distribution. }\end{array}$ & $\begin{array}{l}\text { Oaxaca-Blinder } \\
\text { decomposition }\end{array}$ \\
\hline Turkey & $\begin{array}{l}\text { Tansel } \\
(2004)\end{array}$ & $\begin{array}{c}\text { Household } \\
\text { Expenditure } \\
\text { Survey (1994) }\end{array}$ & $\begin{array}{l}\text { When controlled for observed characteristics and sample selection, for men, public } \\
\text { administration wages are higher than private sector wages except at the university level } \\
\text { where the wages are at par. State owned enterprise wages for men are higher than private } \\
\text { sector wages. Similar results are obtained for women. Further, while wages of men and } \\
\text { women are at parity in the public administration, there is a large gender wage-gap in the } \\
\text { private sector in favor of men. Private returns to schooling are found to be lower in the } \\
\text { noncompetitive public rather than in the competitive private sector. }\end{array}$ & $\begin{array}{l}\text { Oaxaca-Blinder } \\
\text { decomposition. }\end{array}$ \\
\hline Bulgaria & $\begin{array}{l}\text { Dimova } \\
\text { and Gang } \\
(2004)\end{array}$ & $\begin{array}{l}\text { Integrated } \\
\text { Household } \\
\text { Surveyes } \\
(1995,1997 \\
\text { and 2001) }\end{array}$ & $\begin{array}{l}\text { While skilled labor's pattern of reallocation into the public sector remains roughly the same } \\
\text { over time, the inflow of highly educated laborers into the private sector and self- } \\
\text { employment increases. These changes coincide with the erosion of the returns to observed } \\
\text { skills in the private sector and self-employment, while the public sector continues to } \\
\text { reward all types of education at higher than the elementary level. }\end{array}$ & $\begin{array}{l}\text { Earnings } \\
\text { equations after } \\
\text { correcting for } \\
\text { selection bias. }\end{array}$ \\
\hline
\end{tabular}




\begin{tabular}{|c|c|c|c|c|}
\hline Russia & $\begin{array}{c}\text { Lehmann } \\
\text { and } \\
\text { Wadswort } \\
\text { h (2001) }\end{array}$ & $\begin{array}{l}\text { Russian } \\
\text { Longitudinal } \\
\text { Monitor } \\
\text { Survey (1994, } \\
\text { 1995, 1996 } \\
\text { and 1998) }\end{array}$ & $\begin{array}{l}\text { The median gender wage gap would be around twenty-five points higher than the actual } \\
\text { observed gap. Similarly, the counterfactual ratio of mean graduate pay to mean pay of } \\
\text { those with primary education is around twenty points lower than observed. The } \\
\text { parameters of the counterfactual wage distributions are very similar to the parameters of } \\
\text { the observed wage distributions of those not in arrears. For those wishing to study aspects } \\
\text { of wage differentials and inequality in Russia, it may be feasible to use the subset of those } \\
\text { not in arrears and still get close to the true population parameters. }\end{array}$ & $\begin{array}{c}\text { Counterfactual } \\
\text { distributions }\end{array}$ \\
\hline $\begin{array}{l}\text { Czech } \\
\text { Republic, } \\
\text { Bulgaria, } \\
\text { Hungary, } \\
\text { Poland, } \\
\text { Russia, } \\
\text { Slovakia and } \\
\text { Ukraine }\end{array}$ & $\begin{array}{l}\text { Elizabeth } \\
\text { Brainerd } \\
(2000)\end{array}$ & $\begin{array}{l}\text { Household } \\
\text { surveys taken } \\
\text { before and } \\
\text { after the } \\
\text { implementati } \\
\text { on of market } \\
\text { reforms }\end{array}$ & $\begin{array}{l}\text { The results indicate a consistent increase in female relative wages across Eastern Europe, } \\
\text { and a substantial decline in female relative wages in Russia and Ukraine. Women in the } \\
\text { latter countries have been penalized by the tremendous widening of the wage distribution } \\
\text { in those countries. Increased wage inequality in Eastern Europe has also depressed female } \\
\text { relative wages, but these losses have been more than offset by gains in rewards to observed } \\
\text { skills and by an apparent decline in discrimination against women. }\end{array}$ & $\begin{array}{l}\text { Juhn-Murphy- } \\
\text { Pierce } \\
\text { decomposition }\end{array}$ \\
\hline \multicolumn{5}{|c|}{ SA } \\
\hline $\begin{array}{l}\text { Hong Kong, } \\
\text { Korea, } \\
\text { Singapore, } \\
\text { Taiwan, } \\
\text { Indonesia, } \\
\text { Malaysia, } \\
\text { Philippines, } \\
\text { Thailand, } \\
\text { Japan, } \\
\text { India, } \\
\text { China }\end{array}$ & $\begin{array}{l}\text { Meng } \\
(1998)\end{array}$ & & $\begin{array}{l}\text { Female labour participation in most Asian countries is closely linked to national economic } \\
\text { development. Also, it has been found that these changes in technology and world-trade } \\
\text { patterns have caused Asian women to participate more in the non-agricultural sector. } \\
\text { Gender wage differentials are heavily influenced by culture and labour-market } \\
\text { institutional settings but have little to do with economic development }\end{array}$ & Lit. Review \\
\hline $\begin{array}{c}\text { South and } \\
\text { East Asia; } \\
\text { Latin } \\
\text { America }\end{array}$ & $\begin{array}{l}\text { Camps, } \\
\text { Camou, } \\
\text { Maubrigad } \\
\text { es and } \\
\text { Mora-Sitja } \\
(2006)\end{array}$ & $\begin{array}{l}\text { United } \\
\text { Nations } \\
\text { datasets. }\end{array}$ & $\begin{array}{l}\text { In the East Asian, the erosion of the gender gap seems to be mainly explained by the } \\
\text { Stopler-Samuelson and Becker simple model. With the exception of China, the exposure to } \\
\text { international trade openness acts as an engine of erosion of the gender wage differences. } \\
\text { The improvement of women's condition in most of the cases has further consequences for } \\
\text { the analysis of wage inequality. Since traditionally women have been at the bottom of the } \\
\text { wage hierarchy, their economic improvement also narrows wage dispersion and income } \\
\text { inequality. }\end{array}$ & \begin{tabular}{|l} 
Panel Data \\
Models, \\
Gini Index \\
within men and \\
within women
\end{tabular} \\
\hline \multicolumn{5}{|c|}{ EAP } \\
\hline
\end{tabular}




\begin{tabular}{|c|c|c|c|c|}
\hline Indonesia & $\begin{array}{c}\text { Pirmana } \\
(2006)\end{array}$ & $\begin{array}{c}\text { The National } \\
\text { Labour Force } \\
\text { Survey } \\
\text { (SAKERNAS) }\end{array}$ & $\begin{array}{l}\text { The result of estimating Mincerian earnings equation shows that factors as human capital, } \\
\text { socio-demography-economic characteristic and location factors affects significantly } \\
\text { individual earnings. The profile of earnings inequality by gender seems to be an "inverted } \\
\mathrm{U} \text { " fashion, with the male-female earnings gap narrowing as educational attainment went } \\
\text { up. The results also suggest that the industrial affiliation of female workers matter. }\end{array}$ & \begin{tabular}{|c|} 
Mincer \\
equations; \\
Oaxaca-Blinder \\
decomposition
\end{tabular} \\
\hline Mongolia & $\begin{array}{c}\text { Pastore } \\
(2010)\end{array}$ & $\begin{array}{l}\text { School to } \\
\text { Work } \\
\text { Survey } \\
\text { (SWTS) }\end{array}$ & $\begin{array}{l}\text { From the estimation of determinants of gender differences in early career, it was found } \\
\text { that, on average, female wages are not lower than those of males. However, the conditional } \\
\text { gender gap becomes significant and sizeable for the over-20s. The decomposition shows } \\
\text { that most of the gap is due to differences in the way the market values the same } \\
\text { characteristics of men and women. If wages were paid equally, women should have } 11.7 \\
\text { per cent more for their higher education attainment and overall } 22 \text { per cent more. }\end{array}$ & $\begin{array}{l}\text { Juhn-Murphy- } \\
\text { Pierce } \\
\text { decomposition }\end{array}$ \\
\hline Vietnam & Liu (2001) & $\begin{array}{l}\text { Vietnam } \\
\text { Living } \\
\text { Standard } \\
\text { Surveys } \\
\text { (VLSS). }\end{array}$ & $\begin{array}{l}\text { As consequence of the Doi Moi reforms (economic reforms initiated in } 1986 \text { with the goal } \\
\text { of creating a socialist-oriented market economy), absolute gender earnings gap has risen } \\
\text { over time in the private sector; discrimination has increasingly accounted for more of the } \\
\text { gender earnings differences, and it accounts for more of the gap in private sector than in } \\
\text { public sector in 1997-98 than in 1992-93. }\end{array}$ & $\begin{array}{l}\text { Appleton- } \\
\text { Hoddinott- } \\
\text { Krishnan. } \\
\text { Decomposition }\end{array}$ \\
\hline Vietnam & $\begin{array}{c}\text { Liu } \\
\text { (2004b) }\end{array}$ & VLSS. & $\begin{array}{l}\text { Using Juhn et al. (1991) decomposition and data over the period 1992-93 and 1997-98, it is } \\
\text { showed that changes in observed variables have tended to narrow it, but the gap effect has } \\
\text { tended to widen it, with the net effect being one of little change. The experience of } \\
\text { Vietnam, illustrates the importance of discrimination as an obstacle to gender wage gap } \\
\text { convergence. }\end{array}$ & $\begin{array}{l}\text { Juhn-Murphy- } \\
\text { Pierce } \\
\text { decomposition }\end{array}$ \\
\hline Vietnam & $\begin{array}{l}\text { Pham and } \\
\text { Reilly } \\
\text { (2006) }\end{array}$ & $\begin{array}{l}\text { Vietnam } \\
\text {-Household- } \\
\text { Living } \\
\text { Standard } \\
\text { Surveys } \\
\text { (VHLSS). }\end{array}$ & $\begin{array}{l}\text { It is examined the evolution of the gender pay gap for the wage employed over the period } \\
1993 \text { to 2002, and it is found that the transition into market-oriented economy have had a } \\
\text { significant impact on the labour market in Vietnam and have acted to reduce gender wage } \\
\text { disparities in the wage employment sector. The decomposition analysis suggests that the } \\
\text { treatment effect is relatively stable across the conditional wage distribution. }\end{array}$ & $\begin{array}{l}\text { Quantile } \\
\text { Regression } \\
\text { Analysis }\end{array}$ \\
\hline
\end{tabular}




\begin{tabular}{|c|c|c|c|c|}
\hline $\begin{array}{c}\text { Thailand and } \\
\text { Vietnam }\end{array}$ & Son (2007) & $\begin{array}{l}\text { Vietnam: } \\
\text { VLSS } \\
\text { Thailand: } \\
\text { Labor Force } \\
\text { Surveys }\end{array}$ & $\begin{array}{l}\text { Development of a decomposition methodology to explain the welfare disparity between } \\
\text { male and female workers in terms of three components: segregation, discrimination } \\
\text { (earning differential between males and females within occupations), and inequality. It } \\
\text { was found the gender disparity in welfare is largely contributed by the labor market } \\
\text { discrimination against female workers, and the other two components play a smaller role } \\
\text { in explaining the gender welfare gap. }\end{array}$ & $\begin{array}{l}\text { Index of } \\
\text { welfare } \\
\text { disparity }\end{array}$ \\
\hline \multicolumn{5}{|c|}{ WESTERN EUROPE } \\
\hline $\begin{array}{c}\text { Australia, } \\
\text { France, Japan } \\
\text { and Britain }\end{array}$ & $\begin{array}{c}\text { Anne } \\
\text { Daly, } \\
\text { Akira } \\
\text { Kawaguch } \\
\text { i and Xin } \\
\text { Meng } \\
(2006)\end{array}$ & \begin{tabular}{|c|} 
Australian \\
Workplace \\
Industrial Relations \\
Survey (AWIR95), \\
French data are \\
from 1992 French \\
Labour Cost and \\
Wage Structure \\
Survey, Japan data \\
are from the Basic \\
Survey of Wage \\
Structure in 1990 \\
and Britain data are \\
drawn from the \\
British Workplace \\
Employee \\
Relations Survey \\
1998 (WERS98)
\end{tabular} & $\begin{array}{l}\text { Female segregation into low-wage structures emerges as the main contributor to the } \\
\text { gender pay gap, with female segregation into low-wage workplaces as an outstanding } \\
\text { origin of both the gender pay gap in all European economies and of international } \\
\text { differences in its size. On the other hand, international disparities in global characteristics } \\
\text { of the wage structure, and in particular in the extent of wage inequality, are not major } \\
\text { determinants of inter-country differences in the size of the gender wage gap in Europe. A } \\
\text { final point of concern is that cross-country differences in the origin and the magnitude of } \\
\text { the gender gap in pay are particularly significant between the new members of the } \\
\text { European Union, which suggests the existence of a remarkable diversity into this group of } \\
\text { countries. }\end{array}$ & $\begin{array}{l}\text { Updates 1980s } \\
\text { Bob Gregory's } \\
\text { work with } \\
\text { Becker (1975) } \\
\text { and Mincer } \\
\text { (1974) } \\
\text { decomposition. }\end{array}$ \\
\hline $\begin{array}{l}\text { Belgium, } \\
\text { Denmark, } \\
\text { Italy, Ireland, } \\
\text { Spain and } \\
\text { United } \\
\text { Kingdom }\end{array}$ & $\begin{array}{l}\text { Roberto } \\
\text { Plasman } \\
\text { and } \\
\text { Salimata } \\
\text { Sissoko } \\
\text { (2004) }\end{array}$ & $\begin{array}{l}\text { 1995 European } \\
\text { Strusture of } \\
\text { Earnings } \\
\text { Survey (ESES), } \\
\text { gathered by } \\
\text { Eurostat. }\end{array}$ & $\begin{array}{l}\text { The evidence show that the significance of differences in human capital in modeling } \\
\text { gender pay differentials varies across countries. Nevertheless, a common fact among all } \\
\text { countries under study is that these characteristics explain less than } 50 \% \text { of the pay gap. } \\
\text { International comparisons of wage differentials confirm that both gender-specific factors } \\
\text { and wage structure play an important role as gender wage gap is concerned. The striking } \\
\text { results of the adaptation of the Oaxaca-Blinder decomposition for international } \\
\text { comparisons are that countries, which record the lowest gender wage gap and gender } \\
\text { differences in observed productivity characteristics as well as high levels of productive } \\
\text { characteristics. }\end{array}$ & $\begin{array}{l}\text { Oaxaca and } \\
\text { Binder } \\
\text { decomposition, } \\
\text { Blau and Khan } \\
\text { decomposition, } \\
\text { and Brown, } \\
\text { Moon and } \\
\text { Zoloth } \\
\text { decomposition }\end{array}$ \\
\hline
\end{tabular}




\begin{tabular}{|c|c|c|c|c|}
\hline $\begin{array}{c}\text { Austria, } \\
\text { Belgium, } \\
\text { Britain, } \\
\text { Denmark, } \\
\text { Dinland, } \\
\text { France, } \\
\text { Germany, } \\
\text { Ireland, Italy, } \\
\text { Netherlands } \\
\text { and Spain. } \\
\end{array}$ & $\begin{array}{l}\text { Wiji } \\
\text { Arulampal } \\
\text { am, Alison } \\
\text { L. Booth } \\
\text { and Mark } \\
\text { L. Bryan } \\
(2004)\end{array}$ & $\begin{array}{c}\text { European } \\
\text { Community } \\
\text { Household } \\
\text { Panel (ECHP) }\end{array}$ & $\begin{array}{l}\text { The gender pay gaps are typically bigger at the top of the wage distribution, a finding that } \\
\text { is consistent with the existence of grass ceilings. For some countries gender pay gaps are } \\
\text { also bigger at the bottom of the wage distribution, a finding that is consistent with sticky } \\
\text { floors. The gender pay gap is typically higher at the top than the bottom end of the wage } \\
\text { distribution, suggesting that glasses ceilings are more prevalent than sticky floors and that } \\
\text { these prevail in the majority of our countries. The gender pay gap differs significantly } \\
\text { across the public and private sector wage distribution of each country. }\end{array}$ & $\begin{array}{l}\text { Quantile } \\
\text { regression } \\
\text { Analysis }\end{array}$ \\
\hline Spain & $\begin{array}{c}\text { Catalina } \\
\text { Amuedo- } \\
\text { Dorantes } \\
\text { and Sara } \\
\text { de la Rica } \\
\text { (2005) }\end{array}$ & $\begin{array}{l}1995 \text { and } 2002 \\
\text { Spanish Wage } \\
\text { Structure } \\
\text { Surveys (EES- } \\
95 \text { and EES- } \\
\text { 02) }\end{array}$ & $\begin{array}{l}\text { The raw gender wage gap decreased from } 0.26 \text { to } 0.22 \text { over the course of seven years. } \\
\text { However, even after accounting for workers' human capital, job characteristics, female } \\
\text { segregation into lower-paying industries, occupations, establishments, and occupations } \\
\text { within establishments, women still earned approximately } 13 \text { percent and } 16 \text { percent less } \\
\text { than similar male counterparts as for } 1995 \text { and } 2002 \text {, respectively. Most of the gender wage } \\
\text { gap is attributable to workers' sex. Yet, female segregation into lower-paying occupations } \\
\text { within establishments, establishments and industries accounted for a sizable and growing } \\
\text { fraction of the female-male wage differential. }\end{array}$ & $\begin{array}{c}\text { Bayard, } \\
\text { Hellerstein, } \\
\text { Neumark and } \\
\text { Troske } \\
\text { estimation, } \\
\text { pooled OLS, } \\
\text { fixed-effects, } \\
\text { augmented } \\
\text { pooled OLS. }\end{array}$ \\
\hline $\begin{array}{c}\text { United } \\
\text { States, } \\
\text { United } \\
\text { Kingdom, } \\
\text { Finland, } \\
\text { Denmark, } \\
\text { Germany, } \\
\text { Netherlands, } \\
\text { Belgium, } \\
\text { Austria, } \\
\text { Ireland, } \\
\text { France, Italy, } \\
\text { Spain, } \\
\text { Portugal and } \\
\text { Greece. }\end{array}$ & $\begin{array}{c}\text { Claudia } \\
\text { Olivetti } \\
\text { and } \\
\text { Barbara } \\
\text { Petrongolo } \\
\text { (2006) }\end{array}$ & $\begin{array}{l}\text { Panel Study of } \\
\text { Income } \\
\text { Dynamics } \\
\text { (PSID) for the } \\
\text { US and the } \\
\text { European } \\
\text { Community } \\
\text { Household } \\
\text { Panel Survey } \\
\text { (ECHPS) for } \\
\text { Europe. Period } \\
\text { 1994-2001. }\end{array}$ & $\begin{array}{l}\text { Recover information on wages for those not in works in a given year using alternative } \\
\text { imputation techniques. Imputation is based on (i) wage observations from other waves in } \\
\text { the sample, (ii) observable characteristics of the non-employed and (iii) a statistical } \\
\text { repeated-sampling model. The authors estimate median wage gaps on the resulting } \\
\text { imputed wage distributions and obtain higher median wage gaps on imputed rather than } \\
\text { actual wage distributions for most countries in the sample. Correction for employment } \\
\text { selection explains more than a half of the observed correlation between wage and } \\
\text { employments gaps. }\end{array}$ & $\begin{array}{l}\text { Heckman's } \\
\text { two-stage } \\
\text { parametric } \\
\text { approach }\end{array}$ \\
\hline
\end{tabular}




\begin{tabular}{|c|c|c|l|c|}
\hline Spain & $\begin{array}{c}\text { Sara de la } \\
\text { Rica, Juan } \\
\text { J. Dolado } \\
\text { and } \\
\begin{array}{c}\text { Vanesa } \\
\text { Llorens } \\
(2005)\end{array}\end{array}$ & $\begin{array}{c}\text { European } \\
\text { Community } \\
\text { Household } \\
\text { Panel (ECHP- } \\
99)\end{array}$ & $\begin{array}{l}\text { In contrast with the steep pattern found for other countries, the flatter evolution of the gap } \\
\text { in Spain hides a composition effect when the sample is split by education. For the group } \\
\text { with college/tertiary education, we find a higher unexplained gap at the top than at the } \\
\text { bottom of the distribution, in accordance with the conventional glass ceiling hypothesis, } \\
\text { while for the group with lower education, the gap is much higher at the bottom than at the } \\
\text { top of the distribution, }\end{array}$ & $\begin{array}{l}\text { Oaxa-Blinder } \\
\text { decomposition. }\end{array}$ \\
\hline
\end{tabular}


Annex 2.

Weights of Democracy Indicator

\begin{tabular}{lc}
\hline \hline Authority Coding & $\begin{array}{c}\text { Scale } \\
\text { Weight }\end{array}$ \\
\hline Competitiveness of executive Recrudiment & \\
(XRCOMP): & +2 \\
(1) Selection & \\
Opennes of Executive Recruitmen (XROPEN): & \\
only if XRCOMP is coded Selection (1) & +1 \\
(1) Closed & +1 \\
(2) Dual/designation & \\
Contraints on Chief Executive (XCONST): & +3 \\
(1) Unlimited authority & +2 \\
(2) Intermediate category & +1 \\
(3) Slight to moderate limitations & \\
Regulation of participation (PARREG) & +2 \\
(4) Restricted & +1 \\
(3) Sectarian & \\
Competitiveness of Participation (PARCOMP): & +2 \\
(1) Repressed & +1 \\
(2) Suppressed & \\
\hline \hline
\end{tabular}

Source: Policy IV Indicators 